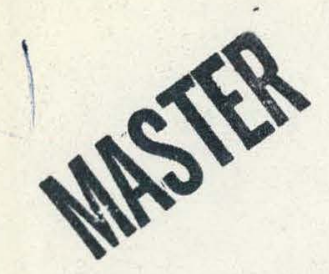

EXECUTIVE SUMMARY

WORKSHOP ON POWER CONDITIONING

FOR

ALTERNATIVE ENERGY TECHNOLOGIES

Denver, Colo, May 9-11, 1979

By

D. R. SMITH

This report was prepared as an account of work
sponsored by the United States Government. Neither the
United States nor the United States Department of
Energy, nor any of their employees, nor any of their
contractors, subcontractors, or their employees, makes
any warranty, express or implied, or assumes any legal
liability or responsibility for tie accuracy, completeness
or usefulness of any information, apparatus, product or
process disclosed, or represents that its use would not
infringe privately owned rights.

SANDIA LABORATORIES 


\section{DISCLAIMER}

This report was prepared as an account of work sponsored by an agency of the United States Government. Neither the United States Government nor any agency Thereof, nor any of their employees, makes any warranty, express or implied, or assumes any legal liability or responsibility for the accuracy, completeness, or usefulness of any information, apparatus, product, or process disclosed, or represents that its use would not infringe privately owned rights. Reference herein to any specific commercial product, process, or service by trade name, trademark, manufacturer, or otherwise does not necessarily constitute or imply its endorsement, recommendation, or favoring by the United States Government or any agency thereof. The views and opinions of authors expressed herein do not necessarily state or reflect those of the United States Government or any agency thereof. 


\section{DISCLAIMER}

Portions of this document may be illegible in electronic image products. Images are produced from the best available original document. 


\section{The following pages are an exact representation of what is in the original document folder.}




\section{EXECUTIVE SUMMARY}

D. R. Smith

Sandia Laboratories

As various alternative energy technologies such as photovoltaics, wind, fuel cells, and batteries are emerging as potential sources of energy for the future, the need for development of suitable power conditioning systems to interface these sources to their respective loads becomes more apparent. Since most of these sources produce DC electricity while most electrical loads require $A C$, an important component of the required power conditioning units is a $D C-A C$ inverter. Although each of these units will interface with an AC load and perhaps the utility grid, the respective soürce chäräcteristics will be greatiy different. This Workshop on Power Conditioning for Alternative Energy Technologies was particularly appropriate at this time as a first step in coordinating the development of power conditioners for each alternative energy technology to avoid duplication of effort and to provide an opportunity to discuss problems in power conditioning development which may be common to several technologies.

The Workshop was sponsored by the U. S. Department of Energy and was co-hosted by the Solar Energy Research Institute and Sandia Laboratories. It was held in Denver, Colorado, at the Hilton Hotel, May 9-11, 1979. Its purpose was to bring together the expertise of those working various alternative energy $R$ and $D$ areas, power conditioning manufacturers, component suppliers, program administrators, and potential users. Discussion topics included a ssessments of current technology, identification of operational requirements with a comparison of requirements for each source technology, the identification of future technology trends, the determination of mass production and marketing requirements, and recommendation for program direction.

During the first day, invited papers of a tutorial nature (abstracts and vugraphs of which appear in these proceedings) were presented. Concurrent working group sessions were held on the 
second day, three in the morning and three in the afternoon. The morning groups were divided according to source technology: photo= voltaics, fuel cells and batteries, and wind; while the afternoon sessions were structured according to system size and application: large grid-connected systems, small grid-connected systems, and stand alone and dc applications. A combined session was held on the third day with summaries presented by the working group leaders. Written summaries of these sessions are also included in these proceedings.

Highlights of the working group sessions are presented in this Executive Summary. For more detailed discussions, the reader is referred to the individual working group summaries.

Power conditioning technology development has taken place in the past, primarily in four main application areas: uninterruptable power supplies (ups), AC motor speed control, high voltage DC (HVDC) transmission, and VAR generation for harmonic filtering and power factor correction. More recently, efforts have been undertaken to develop power conditioners for battery and fuel cell load-leveling applications (BEST and Con Ed programs) and for photovoltaic sources. As a result, hardware has become available, either off-the-shelf or as a developmental unit, in power ratings from less than $1 \mathrm{~kW}$ up to 14MW. Efficiencies of greater than $90 \%$ are currentiy achievable, and with advanced technology, efficiencies of $96 \%$ full load and $92 \%$ quarter load appear feasible. Although projected costs in quantity production differ, especially at the lower power ratings, it appears that achievable cost goals are: less than $\$ 200 / \mathrm{kW}$ for $10 \mathrm{~kW}$ residential units and about $\$ 50 / \mathrm{kW}$ for $14 \mathrm{MW}$ units. Both line commutated and force commutated designs exist at both ends of the power range, and neither appears more viable than the other at this time.

Power quality is an important issue for utility-connected systems and will become more important as large numbers of systems are connected to the grid. A need was expressed by several of the grou 
for power quality standards. Although there is no utility consensus on the matter, power factors in the range 0:9 lead/1ag and harmonic distortions of $10 \%$ for current and $5 \%$ for voltage are being considered.

Reliability figures have been established by experience with UPS systems. Design life of 10-20 years appears acceptable, and 17,000 hour MTBF, corresponding to 5-7 years for photovoltaic systems, are achievable. There is a need for more units to be built and fielded to obtain better reliability data. "One year warranties will probably become standard, and repair by local technicians appears feasible for residential systems.

Safety is also an area of concern, especially for utility connected systems in which the possibility of energizing a "dead" utility line exists. Utility management of system controls appears to be necessary in order to protect utility personnel. while servicing transmission and distribution equipment, unless an automatic, fail safe disconnect scheme can be developed.

In addition to uniform power quality standards, and a fail safe disconnect method, a computer simulation study was recommended in order to assess the impact of a large number of dispersed power systems upon the utility grid, looking at network resonances, stability, and EMI effects. The results of the study could be examined experimentally at a later date when actual systems are connected to the grid. The feasibility of producing power conditioners at even lower costs than currently projected should be investigated, and a limited number of "high risk" advanced technology power conditioning development programs should be funded. Designs which minimize raw material and utilize available low cost solid state power devices are preferable. The development of low cost magnetics and dc switchgear should be pursued. For dc systems and possibly even for large photovoltaic ac systems, there is a need to develop a line of low cost dc-dc converters. 
Thus, even though inverter technology is relatively mature, there are many problems which still need to be solved in the development of power conditioners for the alternative energy technologies. Also, as new power electronic devices, such as power FET's and gate-turn-off SCR's, become available in power ranges of interest and at low cost, power conditioner designs offering greater reliability and even lower cost become a real possibility. 
SUPPLEMENT TO:

POWER CONDITIONING FOR PHOTOVOLTAICS

By

D. R. SMITH

SANDIA LABORATORIES 


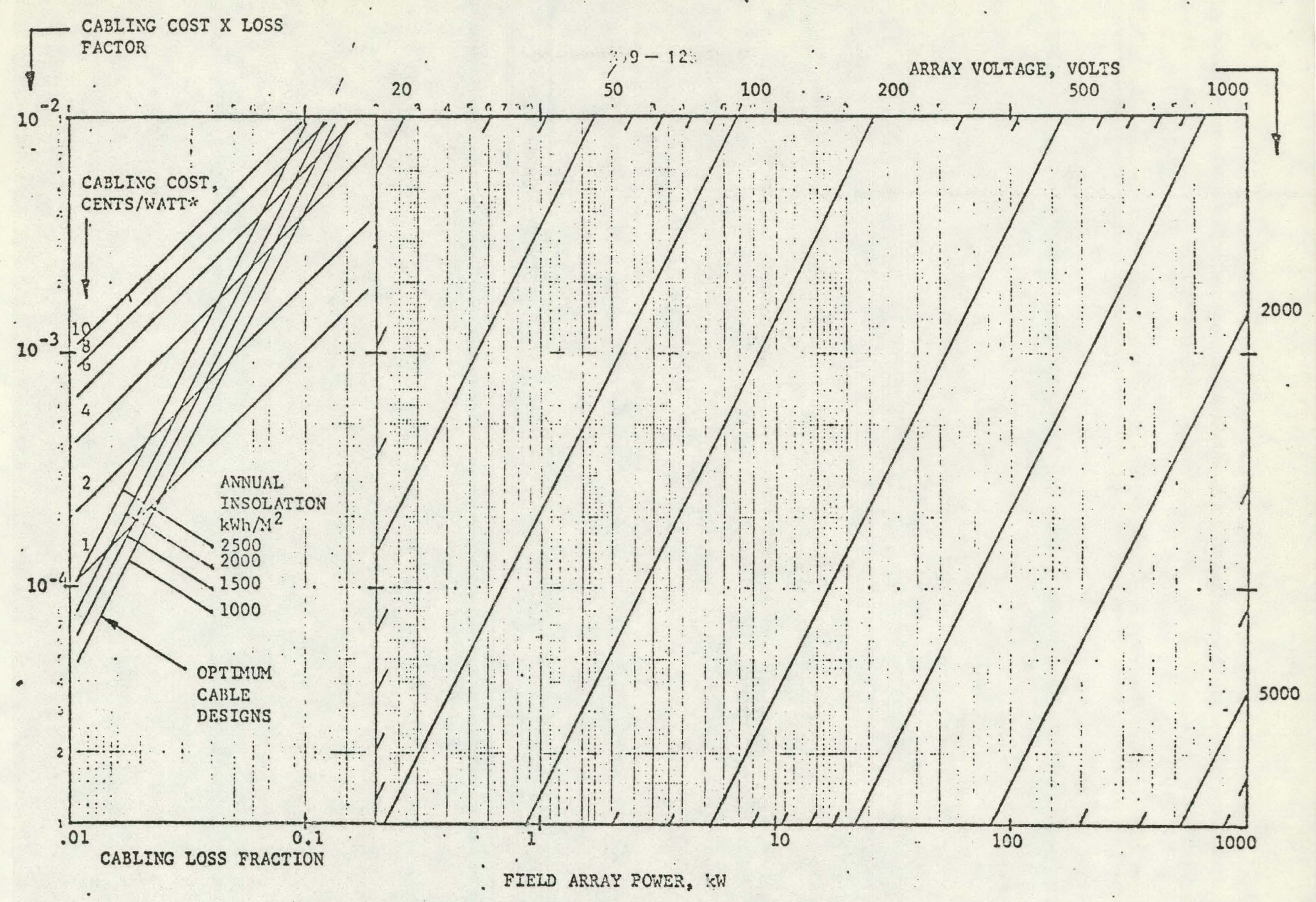

*Use $\$ 1.70 /$ Ih to determinr cobling 
PONER CONDITIONING IN

\section{OTHER PV APPLICATIONS EXPERIMENTS}

\section{APPLICATION}

IRRIGATION PUMPING

MEAD, NEBRASKA

PARK HEADQUARTERS

NAT, BRIDGES, UTAH

RADIO STATION

BRYAN, OHIO

TEST FACILITY

LEXINGTON, MASS,

TEST FACILITY

ARLINGTON, TEXAS

RADAR FACILITY

MT, LAGUNA, CALIF,

MISSISSIPPI COUNTY

COMMUNITY COLLEGE

BLYTHEVILLE, ARK,

NW MISSISSIPPI

JUNIOR COLLEGE

SENATOBIA, MISS,

DC APPLICATION

SCHSHULI VILLAGE

ARIZONA

REMOTE VILLAGE

UPPER VOLTA, AFRICA

VILLAGE POWER SYSTEM

SAUDI ARABIA
OPERATED BY

MIT-LINCOLN

NOVA

$22.5(3 \times 7.5)$

MIT-LINCOLN

MIT-LINCOLN

MIT--LINCOLN

UT-ARLINGTON

MIT-LINCOLN

DOD -

MIRADCOM

CYBEREX
NOVA

NOVA

ABACUS

WINDWORKS

DELTA

DELTA

TBD

NASA-LEWIS

NASA-LEWIS

SER I
8

300

(RFQ)

$3 \times 50$
$1 \times 2$

$1.8 \mathrm{~kW}$

KVA RATING

50 (UPS)

5

6

60

$3.5 \mathrm{~kW}$

TBD
$(R F Q)$

350 


\section{DEPARTMENT OF ENERGY PERSPECTIVES \\ ON}

POWER CONDITIONING DEVELOPMENT

BY

A. S. CLORFEIN

$\mathrm{DOE} / \mathrm{ET}$ 


\section{U.S. DEPARTMENT OF ENERGY PHOTOVOLTAICS PROGRAM}

\section{OVERALL OBJEctive:}

To achieve major cost reduction-leading to competitive life-cycle costs-by aggressively pursuing advanced research, technology development, and real-vorld testing, to support the large-scale transfer of the technology to the market place.

\begin{tabular}{|c|c|c|c|}
\hline BASIC GOALS & MODULE PRICES (FOB)* & SYSTEM PRICES* & PRIME APPLICATION \\
\hline 1982 & $\$ 2.80 /$ peak Watt & $\$ 6 \cdot 13 / W$ & Remote/International \\
\hline 1986 & $\$ 0.70 /$ peak Watt & $\$ 1.60-2.20 / W$ & Residences \\
\hline $1990-2000$ & \$0.15-0.50/peak Watt & $\$ 1.10-1.30 / W$ & Utilities \\
\hline
\end{tabular}




\section{PHOTOVOLTAIC PROGRAM STRATEGY REY ELEMENTS}

- Substantial Price Reductions via:

- Aggressive R\&D to establish technical feasibility of advanced materials and devices (CdS ,alpha-Si, semicrystalline Si and other thin-film devices, photochemical and thermophotovoltaic systems, etc.)

- Intensive technology development of flat-plate and concentrator systems (both Si and GaAs)

- Engineering analyses and technology development to lower the balance-ofsystem costs (e.g.. power conditioning, storage, structures and support, marketing and distribution, etc.)

- Design, development and testing of complete PV systems in actual users' environment

- Emphasis on grid-connected distributed residences as an early U.S. wide-scale application

- Support PV performance criteria and test standards development 


\section{KEY MILESTONES IN THE PHOTOVOLTAIC RD\&D PROCESS}

\begin{tabular}{|c|c|}
\hline MUESTONE & DEFBNPTION/REQUIRERENT \\
\hline $\begin{array}{l}\text { Technical Feasibility (TF) } \\
\text { of Components }\end{array}$ & $\begin{array}{l}\text { Tecthrical feasibility is reached for a particular technology when: } \\
\text { (a) stable and reproducible performance characteristics have been } \\
\text { achieved; (b) a laboratory-scale process has been defined that yields } \\
\text { products with consistent charactristics; and (c) analysis indicares that } \\
\text { mass production is technically feasible and likely to yield a technically } \\
\text { and economically viable product after suitable technology } \\
\text { development. }\end{array}$ \\
\hline $\begin{array}{c}\text { Techrology Readiness (TR) } \\
\text { of Components }\end{array}$ & $\begin{array}{l}\text { Technology readiness is achieved: (a) with a successful subscale } \\
\text { demonstration of all of the individual steps in a production process } \\
\text { that would yield economically competitive and reliable products if } \\
\text { produced in sufficient quantity, and (b) when prototyperare available } \\
\text { for intensive performance and reliability analysis. }\end{array}$ \\
\hline System Feasibility (SF) & $\begin{array}{l}\text { System feasibility is achieved in a given application when a } \\
\text { photovoltaic system concept is first carried through design, } \\
\text { installation and operation in an actual user's application. }\end{array}$ \\
\hline System Readiness (SR) & $\begin{array}{l}\text { System readiness is accomplished when fully integrated systems, } \\
\text { using avilable technology-ready components or prototypes thereof, } \\
\text { are designed, built and successfully operated in an actual user's } \\
\text { environment. }\end{array}$ \\
\hline $\begin{array}{l}\text { Commercial Readines' } \\
\text { of Components and Sy }\end{array}$ & $\begin{array}{l}\text { ven ap } \\
\text { e offer }\end{array}$ \\
\hline
\end{tabular}




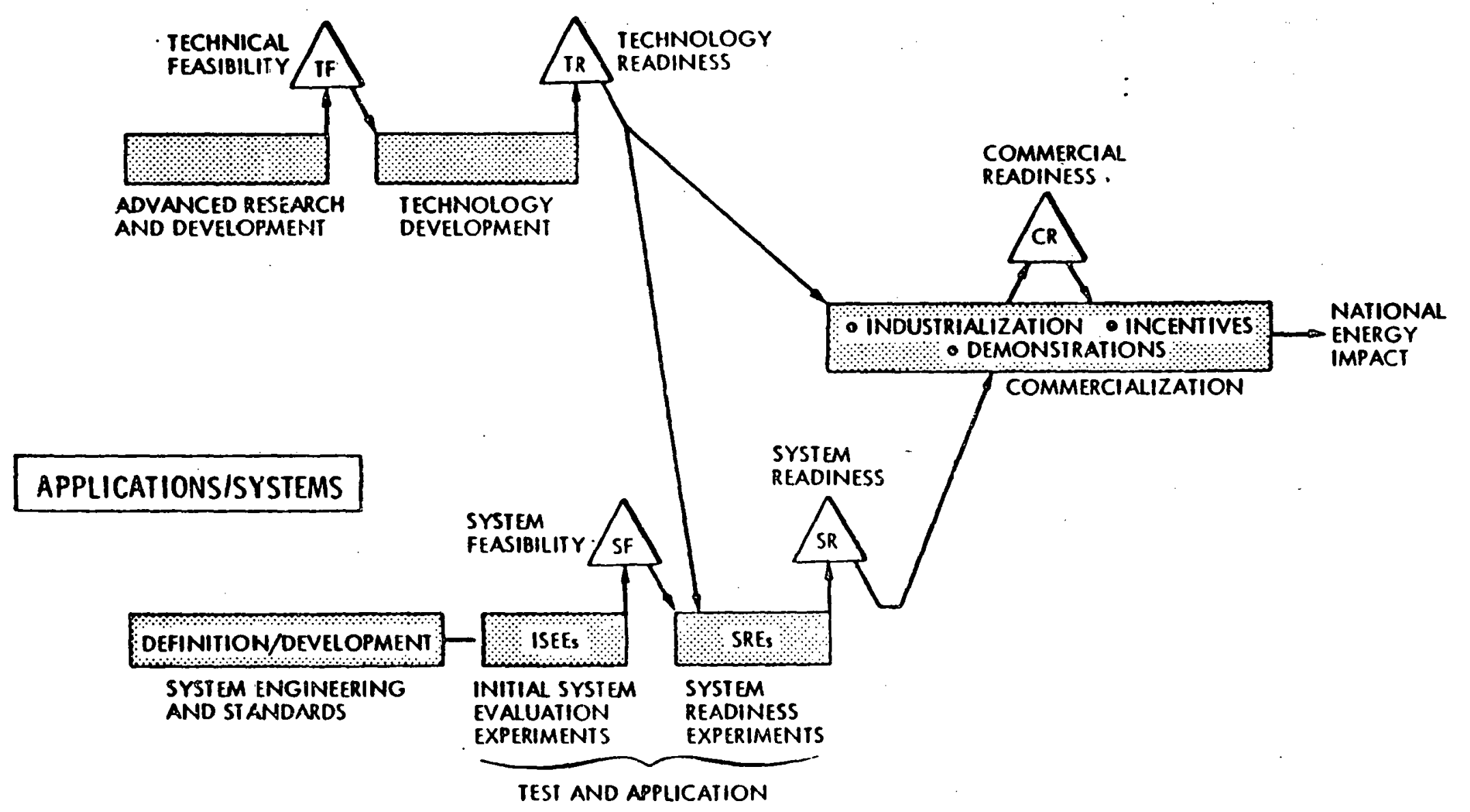

\section{RESEARCH, DEVELOPMENT AND DEMONSTRATION PROCESS. FOR COMPONENTS AND SYSTEMS}




\section{Storage Battery Program Performance Goals Are Different for Different Missions}

\begin{tabular}{|c|c|c|c|}
\hline \multirow[b]{2}{*}{ Parameter } & \multicolumn{3}{|c|}{ Requirement } \\
\hline & $\begin{array}{c}\text { Photovoltaic } \\
\text { System } \\
\text { Storage }\end{array}$ & $\begin{array}{l}\text { Utility Load } \\
\text { Leveling }\end{array}$ & $\begin{array}{l}\text { Electric } \\
\text { Vehicle }\end{array}$ \\
\hline Cost (to O.E.M.) & $\$ 30-35 / k W h$ & $\$ 30 / k W h$ & $\$ 35-40 \mathrm{kWh}$ \\
\hline Cycle Life & 3000 Cycles & 2000 Cycles & $800-1000$ Cycles \\
\hline Service Life & 7-10 Years & 10 Years & 3-10 Years \\
\hline Energy Efficiency & $70-80 \%$ & $70 \%$ & $50 \%$ \\
\hline Energy Density & Not Applicable & Not Applicable & $140 \mathrm{Wh} / \mathrm{kg}$ \\
\hline $\begin{array}{l}\text { Power Density: } \\
\text { Peak (15s) } \\
\text { Sustained }\end{array}$ & $\begin{array}{l}\text { Not Applicable } \\
\text { Not Applicable }\end{array}$ & $\begin{array}{l}\text { Not Applicable } \\
\text { Not Applicable }\end{array}$ & $\begin{array}{r}200 \mathrm{~W} / \mathrm{kg} \\
70 \mathrm{~W} / \mathrm{kg}\end{array}$ \\
\hline $\begin{array}{l}\text { Typical Installation } \\
\text { Size }\end{array}$ & $5 \mathrm{kWh}-600 \mathrm{MWh}$ & 200 MWh & $30-50 \mathrm{kWh}$ \\
\hline Duty Cycle & \begin{tabular}{|l|} 
3-14 h Discharge \\
6-10 h Charge
\end{tabular} & $\begin{array}{l}\text { 4-10 h Discharge } \\
4-7 \text { h Charge }\end{array}$ & $\begin{array}{l}2-4 \mathrm{~h} \text { Discharge } \\
1-6 \mathrm{~h} \text { Charge }\end{array}$ \\
\hline Environmental Impact & NIL & NIL & NIL \\
\hline
\end{tabular}




\section{Storage Battery Program Funding History}

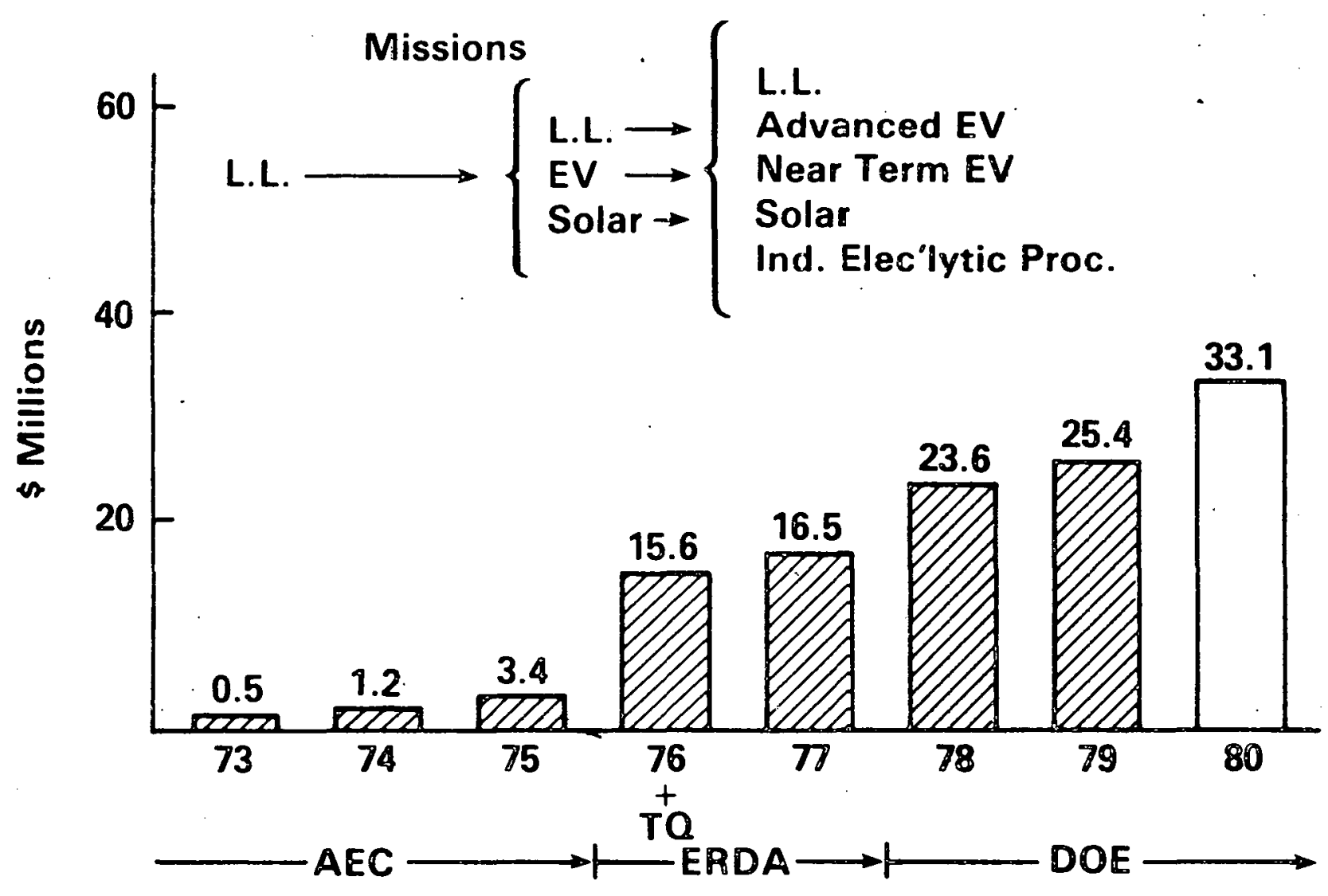




\section{Storage Battery Program}

\section{Expected Battery Requirements for}

Various Applications to Photovoltaic Systems

CHARACTERISTIC

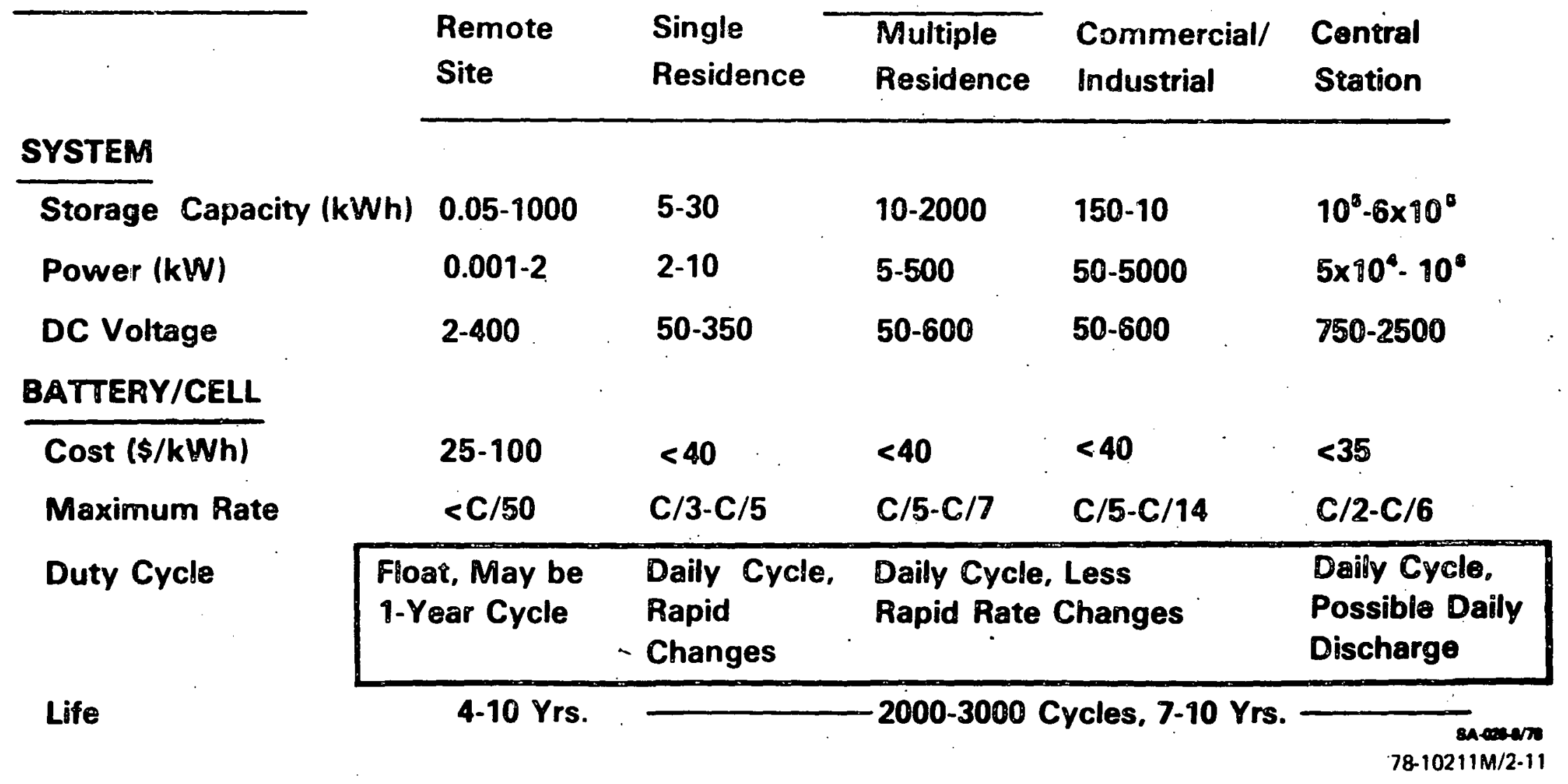




\section{U.S. NATIONAL PHOTOVOLTAIC CONVERSION PROGRAM BUDGET}

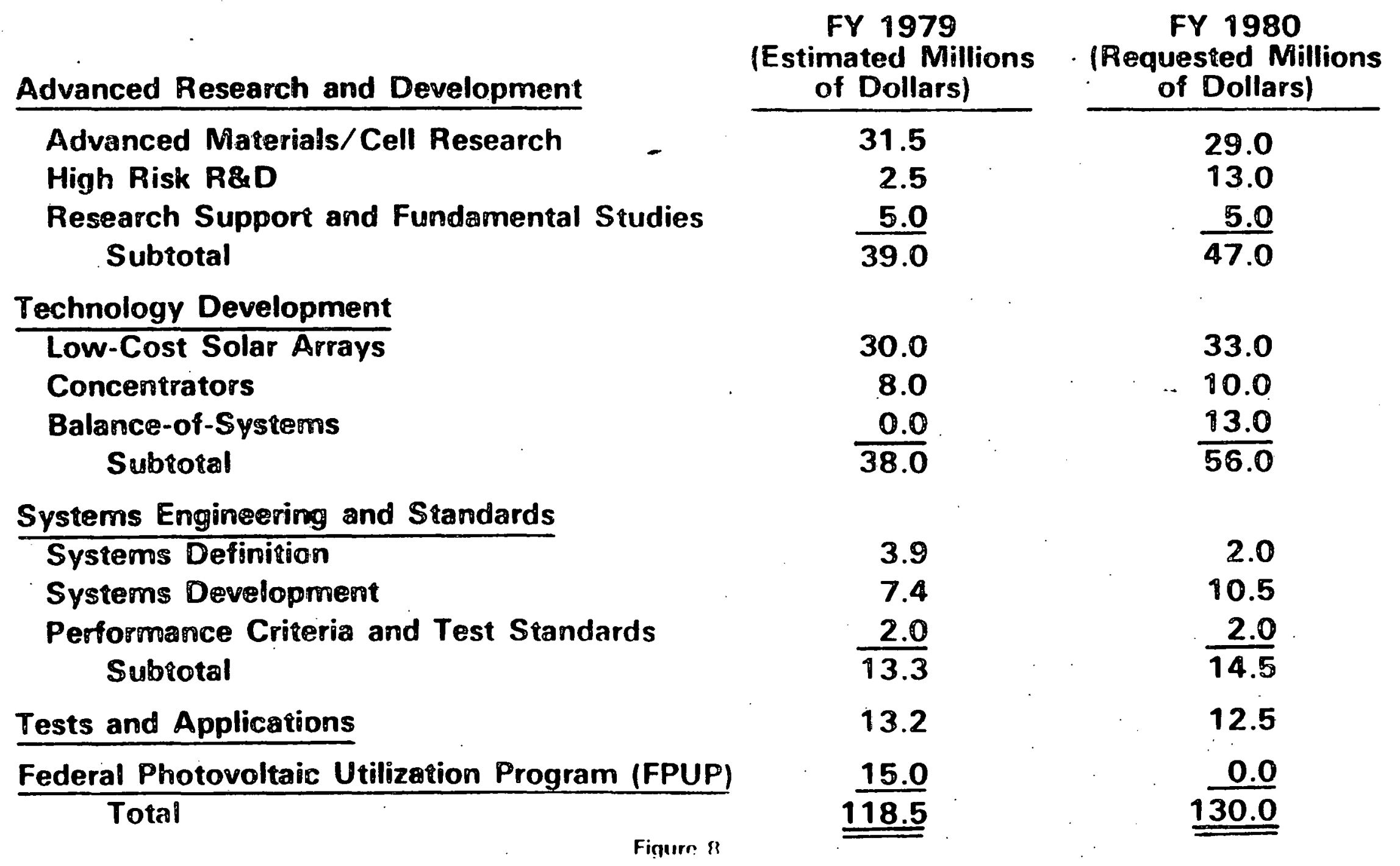




\section{PHOTOVOLTAICS PROGRAM ORGANIZATION}

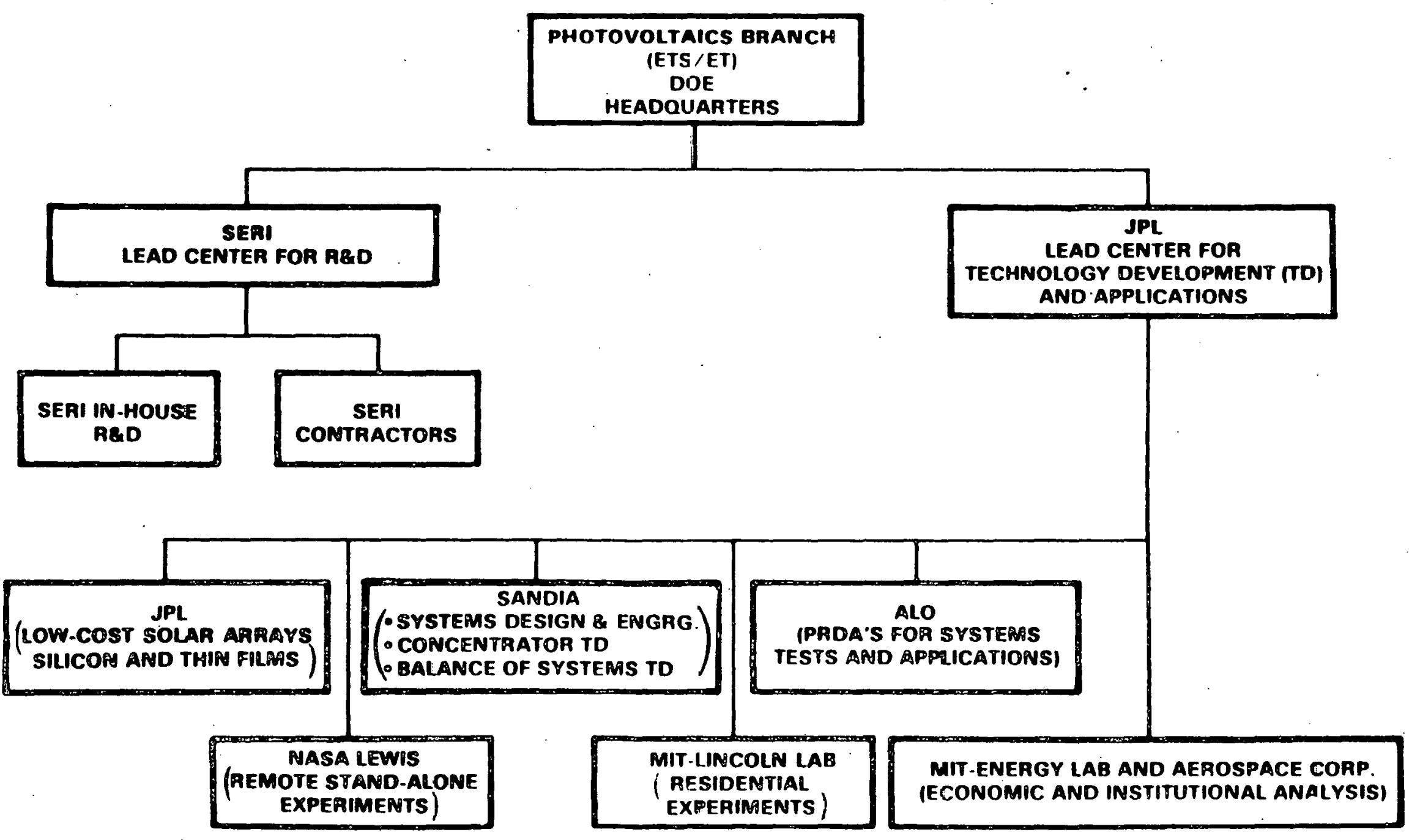

Figure 10 
POWER CONDITIONING EQUIPMENT FOR THE INTEGRATION OF NEW ENERGY SOURCES

BY

DIETRICH J. ROESLER

DOE/ELECTRICAL ENERGY SYSTEMS 
Power Conditioning Equipment for the Integration of New Energy Sources

Dietrich J. Roesler

Electric Energy Systems Division

\section{Background}

Present nationwide electric systems are designed around electric power generation stations. With the emergence of dispersed electric energy generation through new source technologies such as solar photovoltaic, wind, fuel cells and battery storage devices, the present concept of power delfvery must undergo radical design changes to meet the required safety and reliablitity standards. This was recognized by DOE and late in 1978 the Electric Energy Systems (EES) Division was given the explicit mission to develop and carry out a program to integrate new source technologies into the electric power system by utilizing power conditioning equipment. The EES division is well qualified to perform this integration task because of its involvement in near-term and longer range development in electric energy system technologies. Current EES programs include Load Management activities and efforts that are aimed to develop more efficient Systems and to improve system reliability. $\Lambda$ o part of this effort, EE3 is parllelpating in the development of power conditioning equipment for the BEST facility and the 4.8 MW Fuel Cell Demonstration Project. To manage these efforts efficiently, EES has established working relationships with other DOE Organizations, ETS divisions, the Utility and EPRI.

\section{Discussion}

The EES division is part of the office of Solar, Geothermal, Electric and Storage Systems (ETS). The purpose of EES's involvement in the integration of new energy sources with the utility grid is to:

- Define and substantiate current and future efforts for power conditioning integration projects.

- Facilitate coordination within DOE, with EPRI and utilities and with other federal departments.

- Provide guidance for scheduling of projects and estimated funding.

To initiate actions, EES will prepare a development plan for power conditioning integration projects. It is anticipated that the recommendations of this workshop will become an important part of this plan.

The objective of the plan is to coordinate the power conditioning effort between the involved activities in order to develop reliable, 
effictent, low cost power conditioning equipment withtn the required time.

Figure 1 represents a potential electrical energy system for the future, combining traditional electric power generators with new electric energy sources. The operations of a complex network such as that requires new operating concepts and the development of power conditioning equipment. In addition, a number of problems and issues, such as --generation impact, ownership, operational control, equivalent firm capacity, cost/price for backup power, value/prtce for excess energy, storage, harmonics, VAR control etc. -- have to be resolved before the integration of a substantial number of new energy sources into the utility grid can be attempted.

Figure 2 shows a block diagram of a system powered by a new energy source. The system consists of the new energy source, the power conditioning unit and the interface with the utility grid. As can be seen, the power conditioning unit includes all the equipment necessary to connect a new energy source to the utility grid.

Figure 3 shows the principal groups presently involved with the development and integration of PC equipment.

The EES Division in response to its misston will be the focal point of this program. In this role, EES will coordinate the efforts between the principal groups, will manage programs funded by EES and/or other source technology divisions, will distribute findings resulting from the projects and will initiate new and modify existing programs as felt necessary to accomplish the objectives.

The implementation of this plan will provide a mechanism for the timely integration of new source technologies into the power grid, and the organizational set up, will ensure minimal overlapping of programis.

Figure 4 gives the basic concepts which will be followed to develop reliable, efficient, low cost power conditioner systems.

The PC equipment will be developed in three distinct groups; the "Studies and Simulation", the "Design and Hardware Verification" and the "Pllot Production for Commerclal Readiness." Before a project is transferred from one group into the other, a set of Individual milestones has to be met.

The development of the PC equipment starting from studies and ending up in pilot production is straightforward. Major emphasis has to be placed on the generation of practical requirements and 
standards. The requtrements and standards have to be strift enough to produce safe and reliable equipment, but loose enough to pros duce equipment with a low cost.

The evaluation of each individual project will be based on the two major objectives; high effictency and low production cost. If the efficiency and/or cost goals are not within the established limits, the particular project will be re-directed or cancelled. Table 1 shows efficiency and no load loss goals of power condittoners for near term and long term efforts.

Table 1 Efficiency and No Load Losses

\begin{tabular}{|l|l|l|l|r|r|r|}
\hline & \multicolumn{3}{|c|}{ Near Term } & \multicolumn{3}{c|}{ Long Term } \\
\hline Categories & 1 & 2 & 3 & 1 & 2 & 3 \\
\hline Rated Load (\%) & 91 & 93 & 96 & 93 & 95 & 97 \\
\hline Half Load (\%) & 88 & 90 & 94 & 90 & 92 & 95 \\
\hline $\begin{array}{l}\text { No Load Losses } \\
\% \text { of Rated Power }\end{array}$ & $\langle 5$ & $\langle 4$ & $\langle 2$ & $\langle 3$ & $<2$ & $<1$ \\
\hline
\end{tabular}

Category 1: Residential

Category 2: Load Centers

Category 3: Central Power

Figure 5 represents the cost projection of PC systems for different New Source Technologies, such as Photovoltaic and Wind, Fuel Cells and Batteries. The projected cost for the PC production unit is on the average about $1 / 5$ to $1 / 6$ of the current cost.

Up to date, a number of studies and simulations have been performed, hardware has been designed and built and a number of projects have been successfully completed. Based on these efforts, there should be no doubt that with proper planning and funding the goals which have been set for the Integration of New Energy Sources with Power. Conditioning equipment can be met. 


\section{Integration of New Source Technologies}

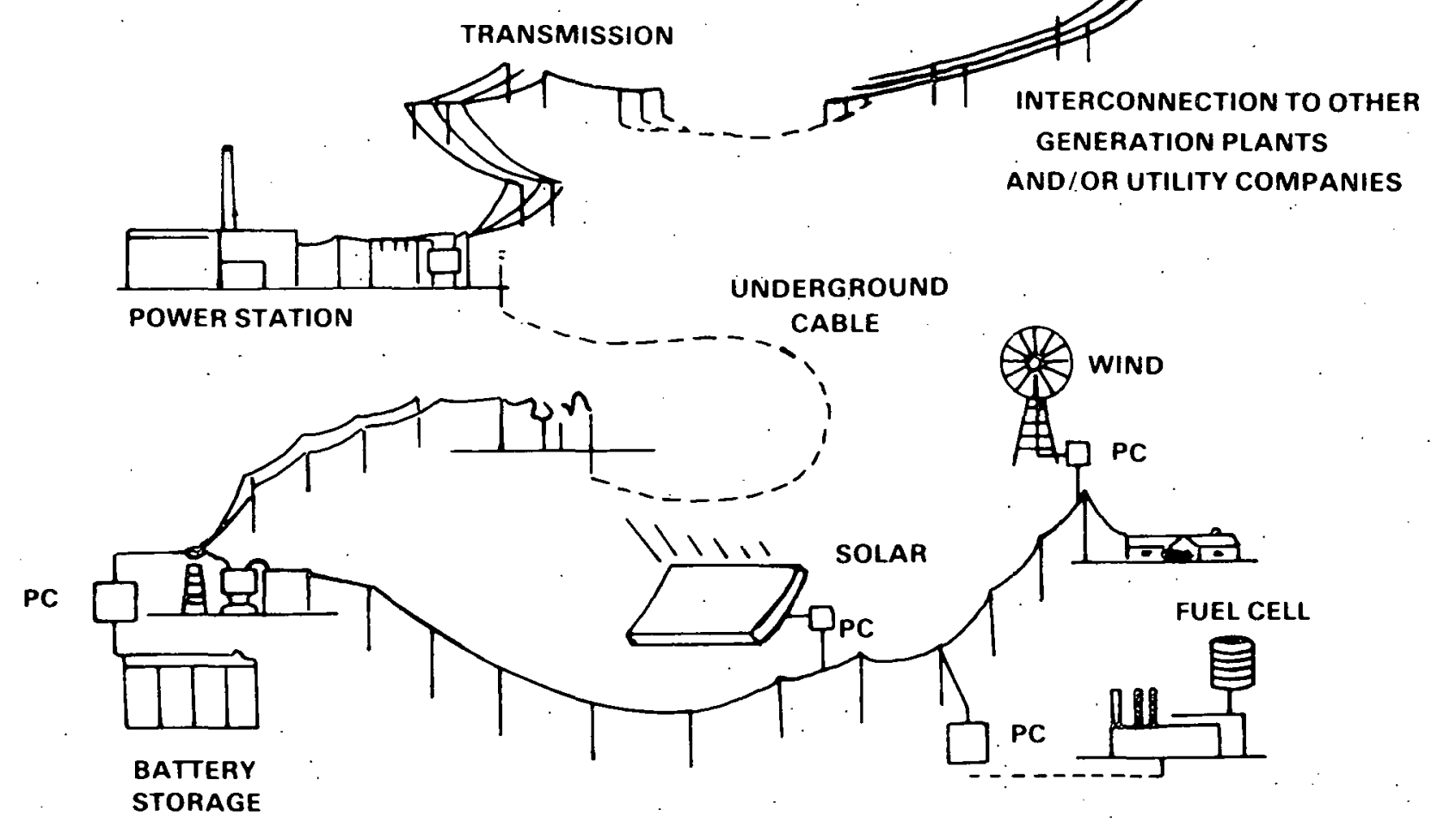

PC: POWER CONDITIONER 
FIGURE 2

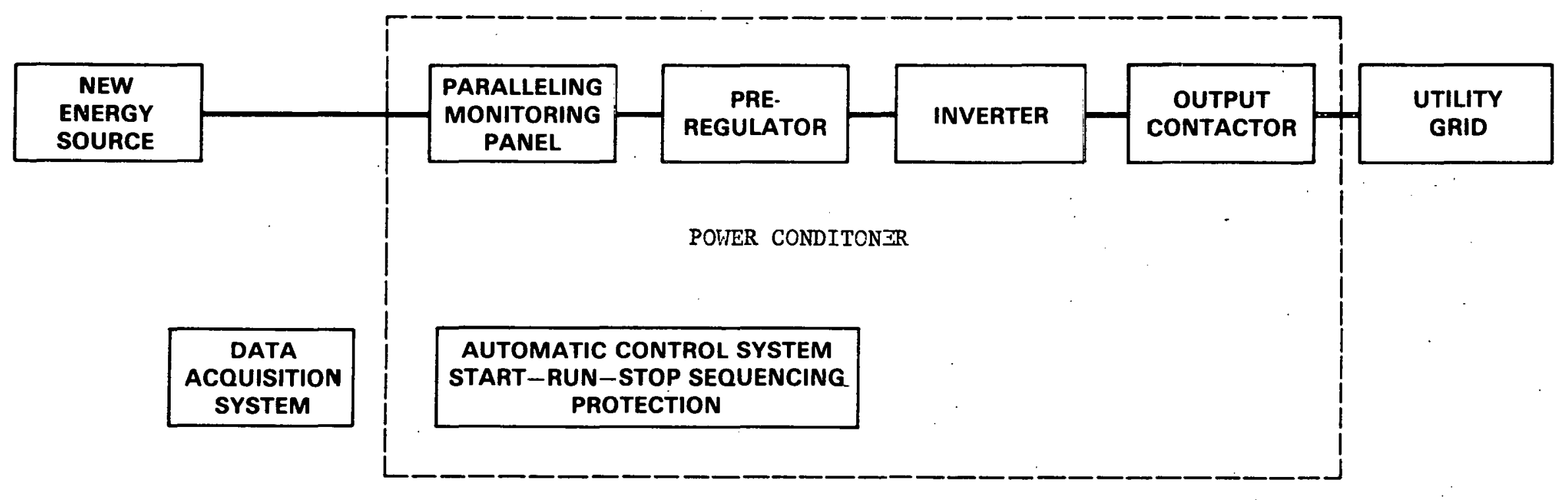

SYSTEM SCHEMATIC 
FIGURE 3

\section{Organizational Chart}

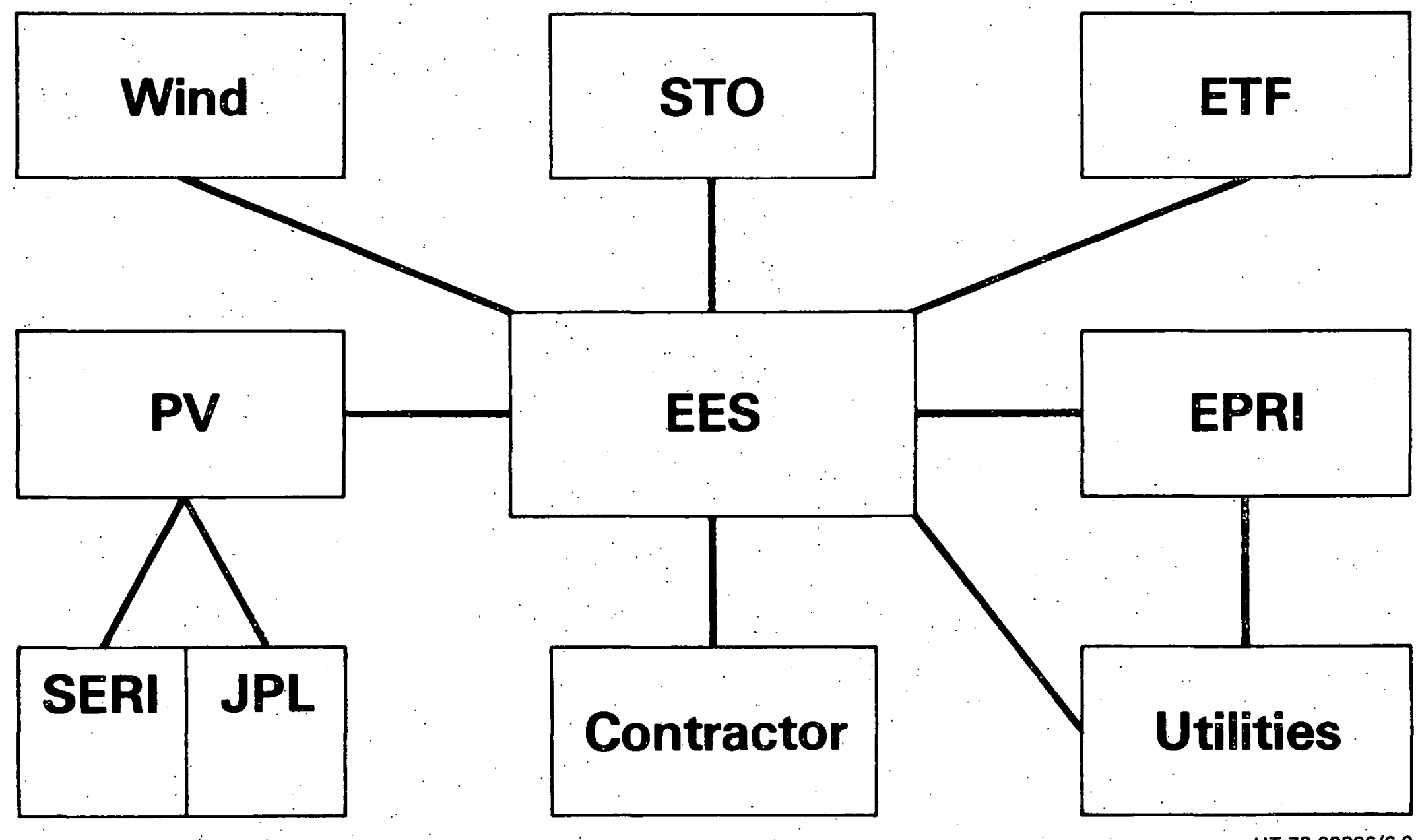




\section{Basic Concepts for Power Conditioning Development}

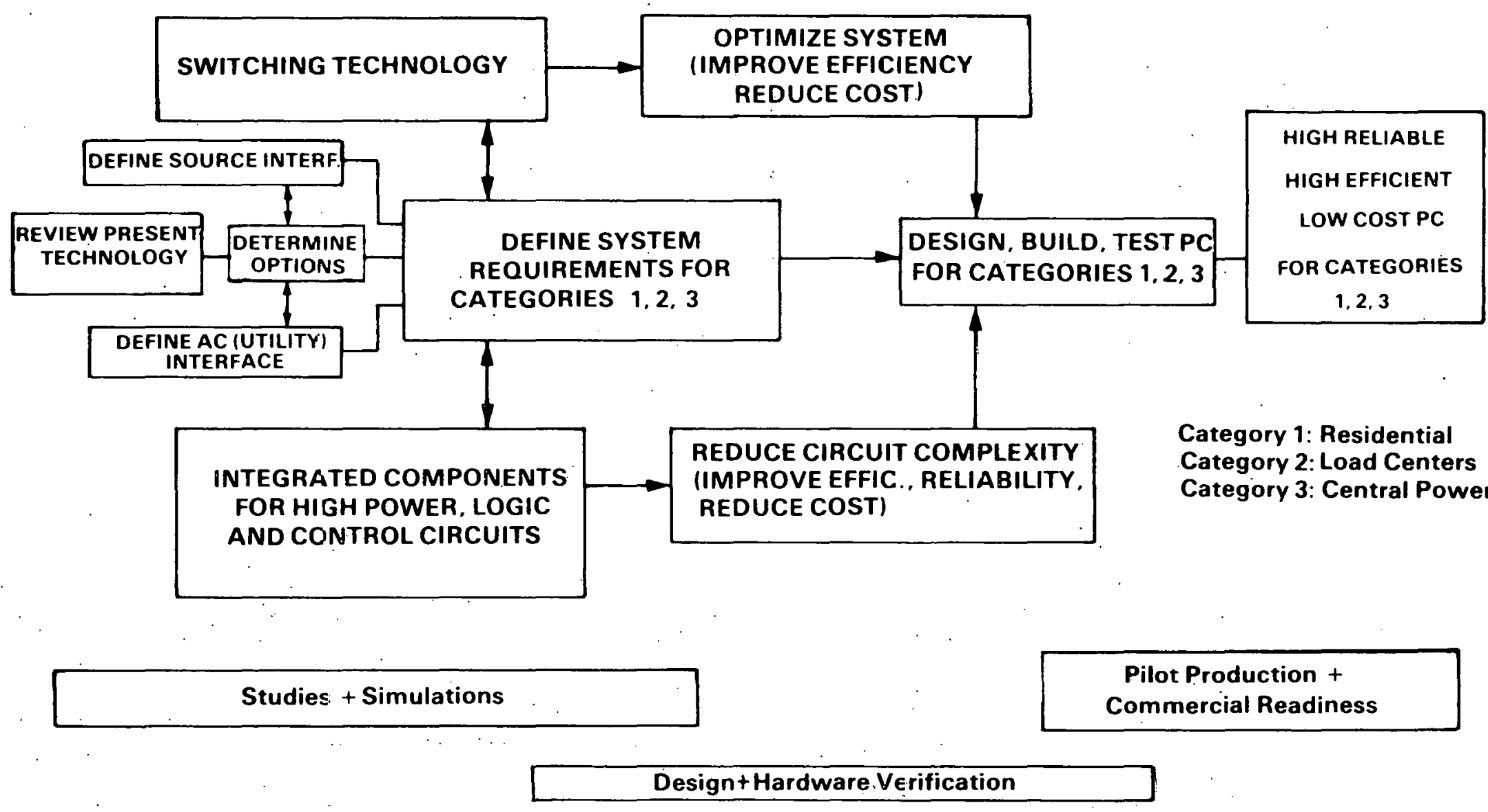




\section{COST PROJECTION OF POWER CONDITIONING SYSTEMS}

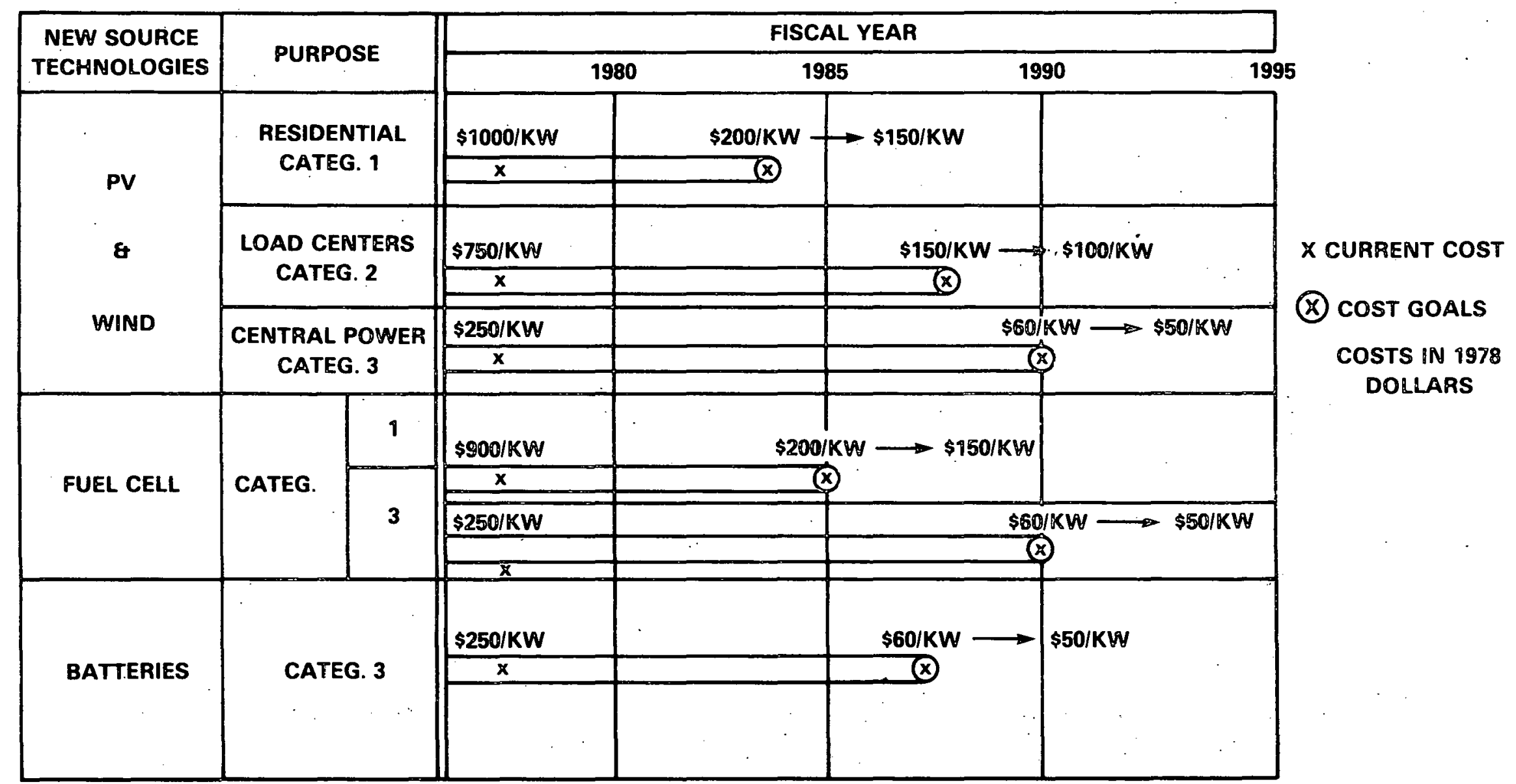


Supplement to:

IMPLICATIONS OF NEW TECHNOLOGY ON

POWER CONDITIONER DESIGN

BY

P. F. PITTMAN

WESTINGHOUSE ELECTRIC 


\section{IMPLICATIONS OF NEW TECHNOLOGY ON POWFR CONDITHONER DESIGN}

- Why is New Technology Needed?

- Is This an Important Problem?

- In Which Areas Can New Technology by Expected? 


\section{NEED FOR NEW TECHNOLOGY}

To Minimize the TPV of Capital and 0 \& M Cost Per kWh of Energy Generated by Trading Off;

- Capital Cost

- 0 \& M Cost

- Performance 


\title{
IMPORTANCE OF PROBIEM
}

\begin{abstract}
Approximate B reakdown of System Capital Costs for the 1990 - 2000 Time Period When the Cost of the Solar Panels Drops to 10 to $20 \mathrm{c} / \mathrm{W}$
\end{abstract}

\begin{tabular}{ccc}
\multicolumn{1}{c}{ Subsystem } & RPS & CPS \\
Power Conditioner & $12 \%$ & $28 \%$ \\
Solar Panels & $23 \%$ & $26 \%$
\end{tabular}




\section{NEW OR IMPROVED TECHNOLOGY}

Circuit Design

- Self-Commutated Circuits

- Line-Commutated Circuits

- Active Filters 


\section{NEW OR IMPROVED TECHNOLOGY}

$\underline{\text { Semiconductor Devices }}$

Improved Devices

- Transistors

- Thyristors

New Devices

- Reverse Conducting Thyristors (RCT)

- Asymmetrical Thyristors

- Gate Assisted Turn-Off Thyristors(GATT)

- Gate Turn-Off Thyristors (GTO)

- Power Field Effect Transistors (FET) 

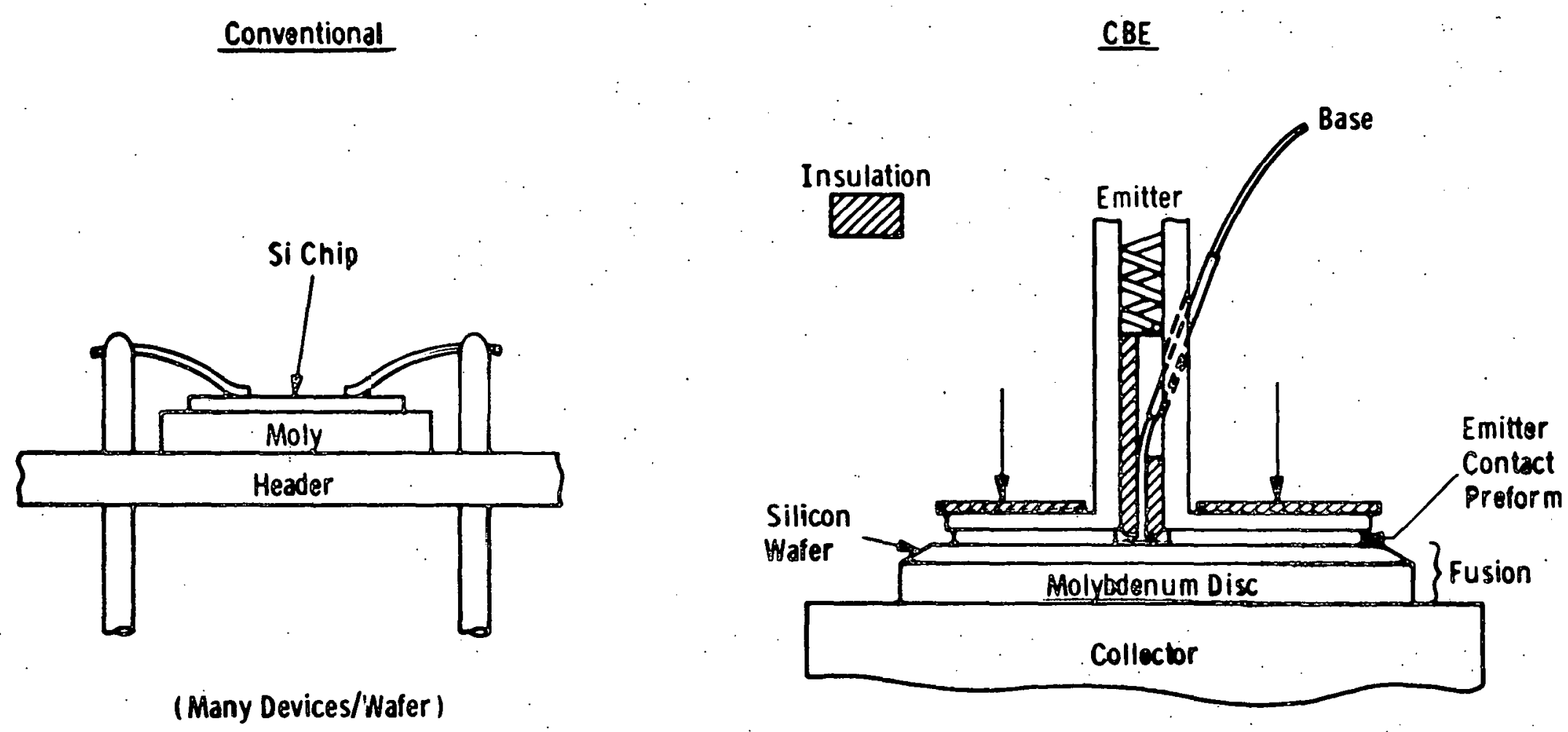


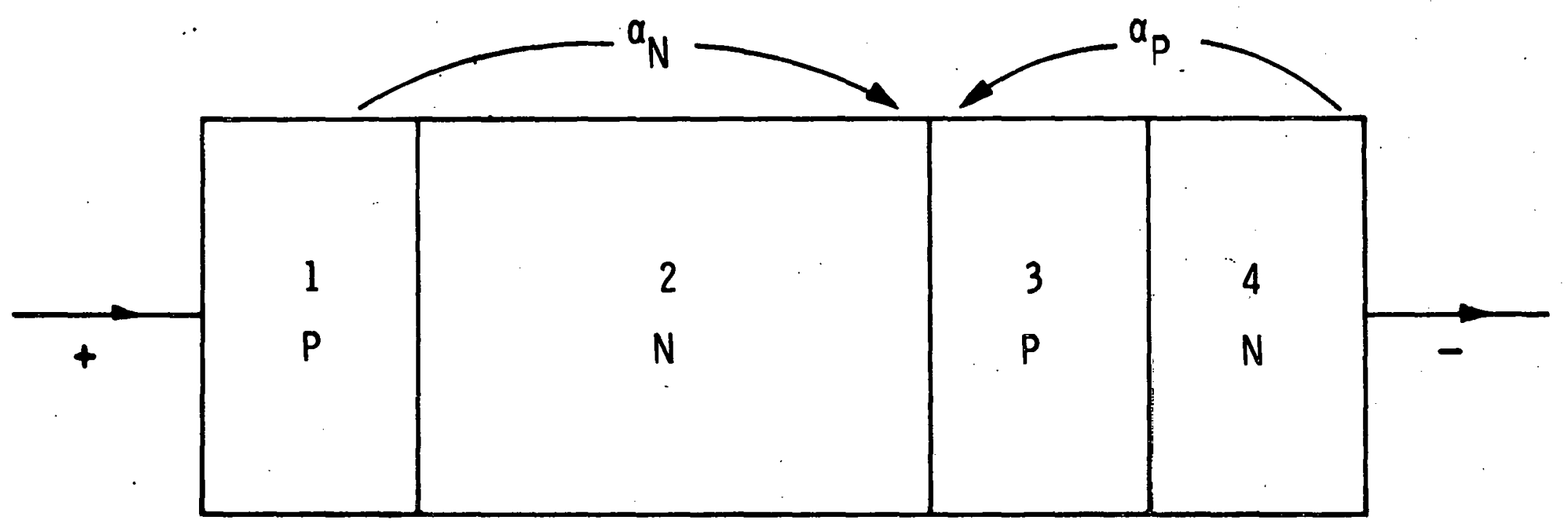

\section{Region 1 Region 2 Region 3 Region 4} Anode Emitter $n$-Base p-Base Cathode Emitter

Doping Concentration

Thickness

Lifetime

Resistivity

$\begin{array}{ll}N_{2} & P_{3} \\ W_{2} & W_{3} \\ \tau_{2} & \tau_{3} \\ P_{2} & P_{3}\end{array}$

$N_{4}$
$W_{4}$
$\tau_{4}$
$P_{4}$

Fig. 1 - Structure of a thyristor 


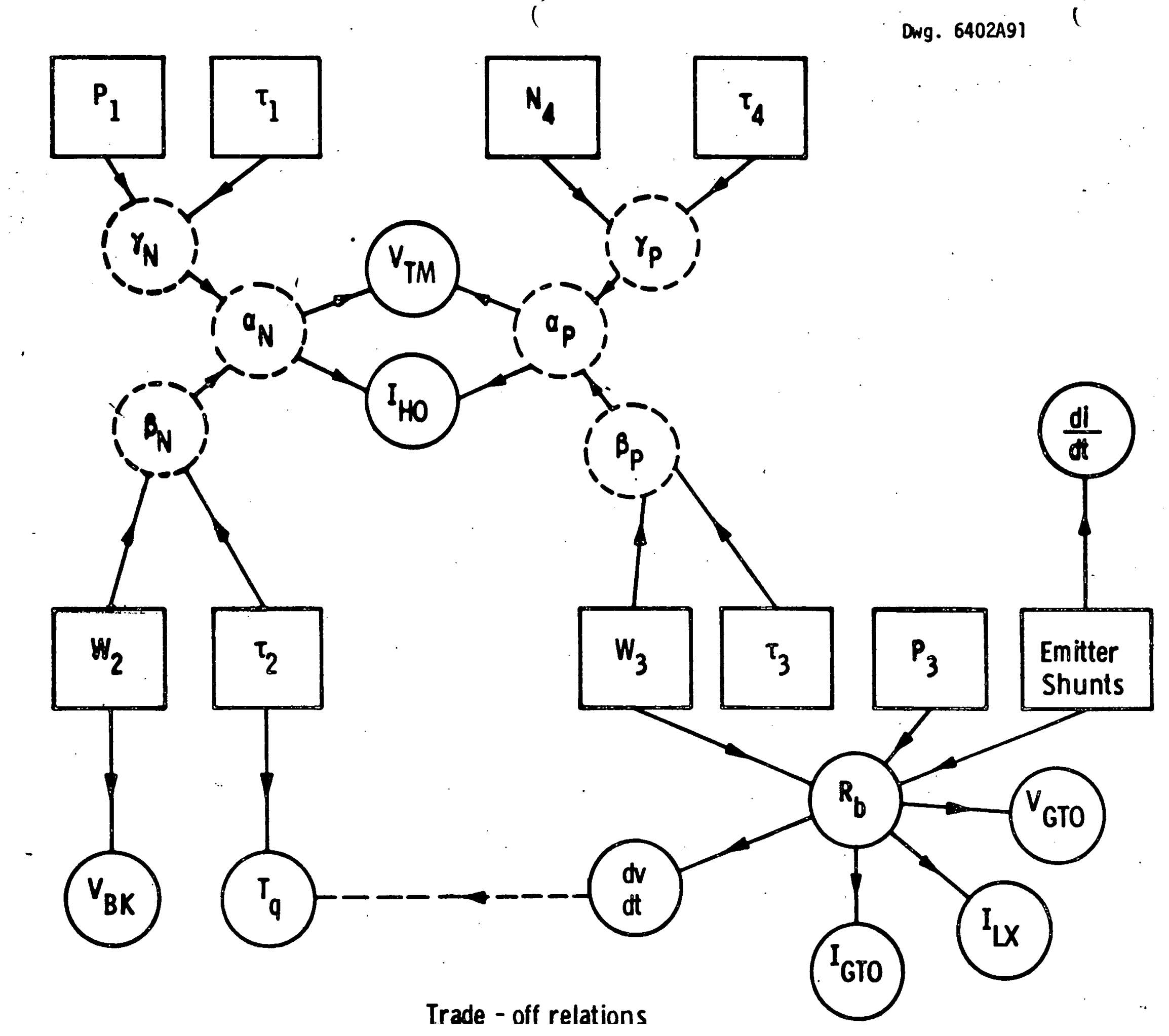




\section{GATE ASSISTED TURN-OFF THYRISTOR}

FAST VOLTAGE BLOCKINE RECOVERY BY APPLYING NEGATIVE GATE CURRENT AT ANODE CURRENT ZERO

ANODE CURRENT

GATE(ASSIST) CURRENT

ANODE VOLTAGE

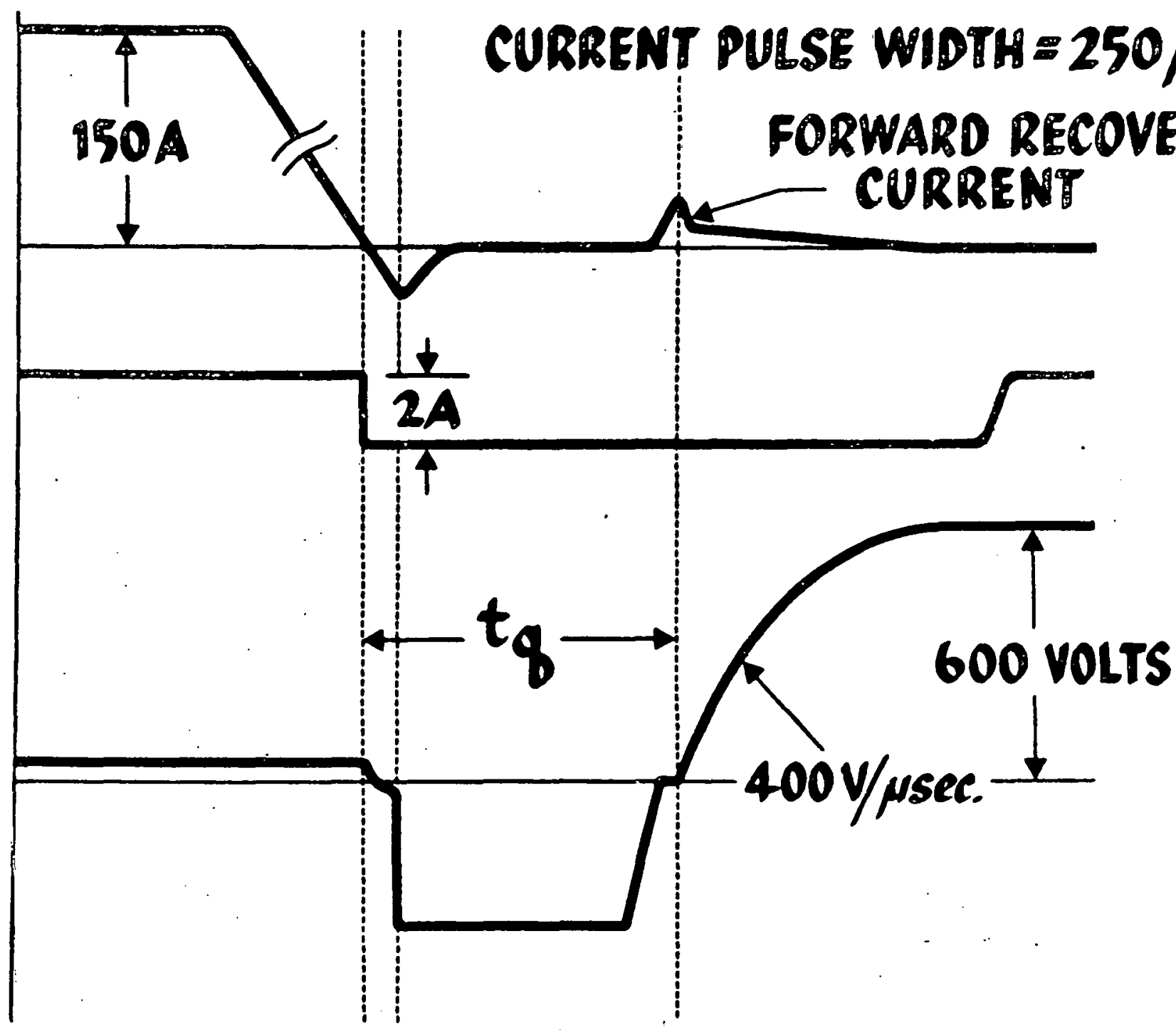

FIg. 1 


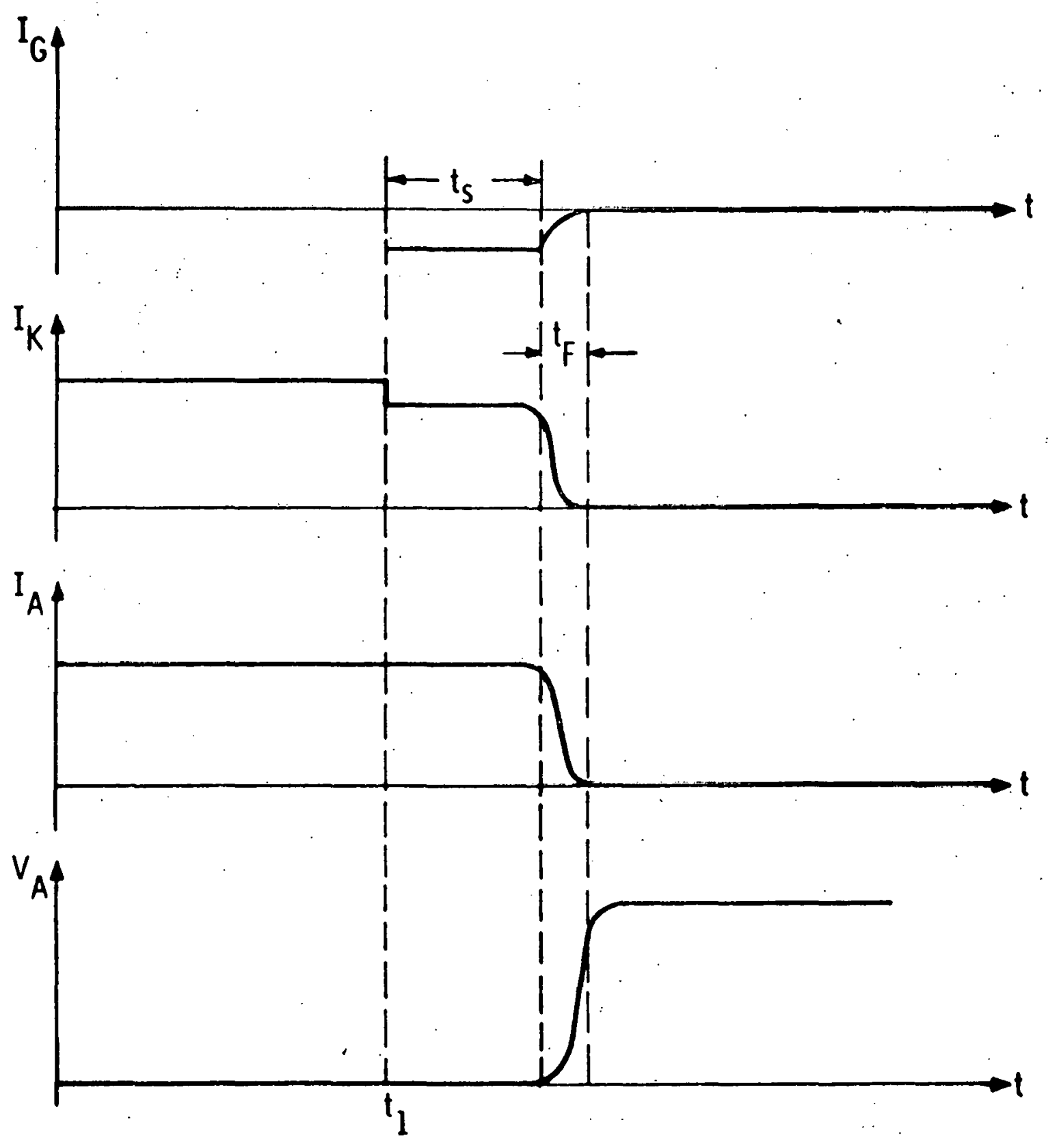

Fig. 2-1-Switching current-voltage wave-forms of GCS when using a a current source as the gate drive 


\section{NEW OR IMPROVED TECHNOLOGY}

\section{Magnetic Devices}

A morphous Magnetic Material with the Potential for:

- Lower Losses

- Reduced Manufacturing Cost 


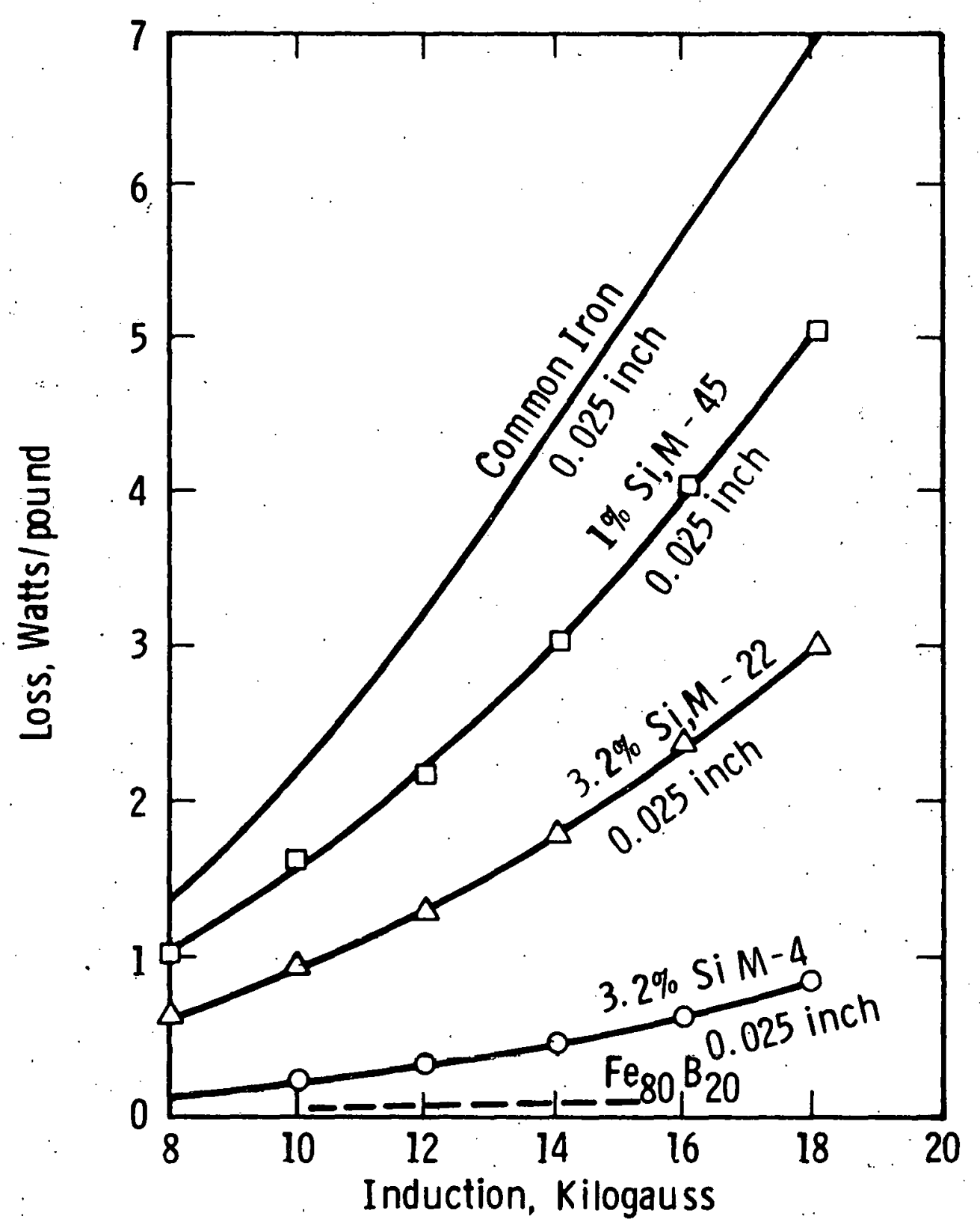

Loss as a function of induction, for sinusoidal flux, for amorphous $\mathrm{Fe}_{8} \mathrm{~B}_{20}$ and some commonly used iron-based magnetic materials. $M-4$ is grain-oriented; the other commercial alloys are not 
NEW OR IMPROVED TECHNOLOGY

Logic and Control

- Greater Use of Microprocessors

- Advanced Microprocessors

- Improved Power Device Modulation

- Improved Output Regulation

- Data Logging

- P.C. Self-Diagnostics

- Unified P.C. and System Control in Smaller Systems

- Unified P.C. and System Self-Diagnostics in Smaller Systems

- Fault Annunciation and Indication 
- Computer Analysis of Circuit Performance

- Computer Analysis and Prediction of PC Reliability

- Computer Simulation of PC Performance in System Applications

- Cost/Performance/Reliability Tradeoffs 


\section{EFFECT OF NEW TECHNOLOGY ON PRODUCTION COST REDUCTION}

- Hybrid Logic Packages

- VLSI Logic Modules

- Customized Integrated Hybrid Power Devices 
Supplement to:

POWER CONDITIONING FOR LOW POWER APPLICATIONS

BY

G. A. 0' SULLIVAN ABACUS CONTROLS INC.

Roy L. PICKRELL NASA/LERC 


$$
\begin{aligned}
& \text { SERI I SANDIA } \\
& \text { Power Conditioning Workshop } \\
& \text { For Alternate Energy Technologies } \\
& \text { May } 9-10,1979 \\
& \text { POWER CONDITIONING FOR LOW POWER APPUCATIONS } \\
& \text { Roy L. Pickrell } \\
& \text { NASA Lewis Res. Cntr. }
\end{aligned}
$$

George 0'Sullivan Abacus Controls Inc. 
RELATION OF SMALL PV SYSTEMS TO OVERALL DOE PV PROGRAM

- REMOTE SMALL PV SYSTEMS ARE FRST TO ACHIEVE ECONOMIC FEASIBILITY Earliest applications in location swhere replenishment of conventional fuel or chemical batteries is diffialt, time consuming, and expensive.

Example: Ranger Lookout Stations

- EARLY PV INSTALLATIONS ARE DC STAND ALONE SYSTEMS

Consist of the Solar Array, DC Bus Regulator, Battery, Load and Load Control -FOLLOW ON INSTALLATIONS MAY BE EXPANDED DC SYSTEMS; AC SYSTEMS OR COMBINATIONS.

Economic Trade Offs will ultimately dictate final configurations.

- SMALL PV SYSTEMS PROVIDE EARLY OPPORTUNITY TO TEST MARKET FEA SIBIUTY 


\section{TECHNICAL CONSIDERATIONS IN BASIC DC PV SYSTEMS}

I. EFFECT OF TEMPERATURE VARIATION ON SOLAR ARRAY PERFORMANCE AND IMPA CT ON OPERATING POINT OF THE BATTERY STABILIZED DC SYSTEM

2. TYPE OF BATTERY DISCHARGE CYCLE AND EFFECT ON DESIGN OF SYSTEM

- Annual Deep Cycle with small daily cycle superimposed and where continuous service is provided.

- Daily Deep Cycle where energy storage is used to extend usful service period.

3. EFFECT OF BATTERY TEMPERATURE ON PERFORMANCE.

4. ARRAY I BATTERY CAPACITY TRADE DFF ANALYSIS WHICH SHOWS EQUAL PERFORMANCE AND POTENTIAL COST IMPUICATIONS.

5. ALTERNATE METHODS OF UMITING DC BUS VOLTAGE TO PREVENT BATTERY OVERCHARGE.

6. METHODS OF DETERMING BATTERY STATE OF CHARGE

7. LOAD MANAGEMENT SYSTEM REQUIREMENTS. 


\section{Power Bus}

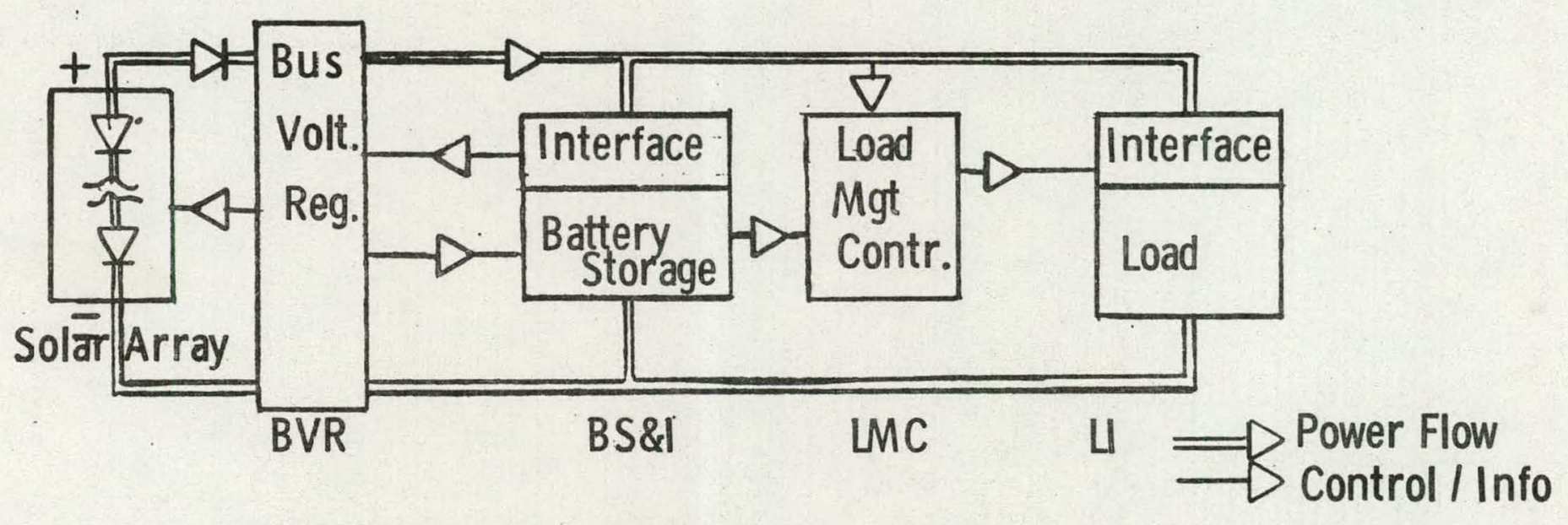

DC STAND ALONE PV POWER SYSTEM 


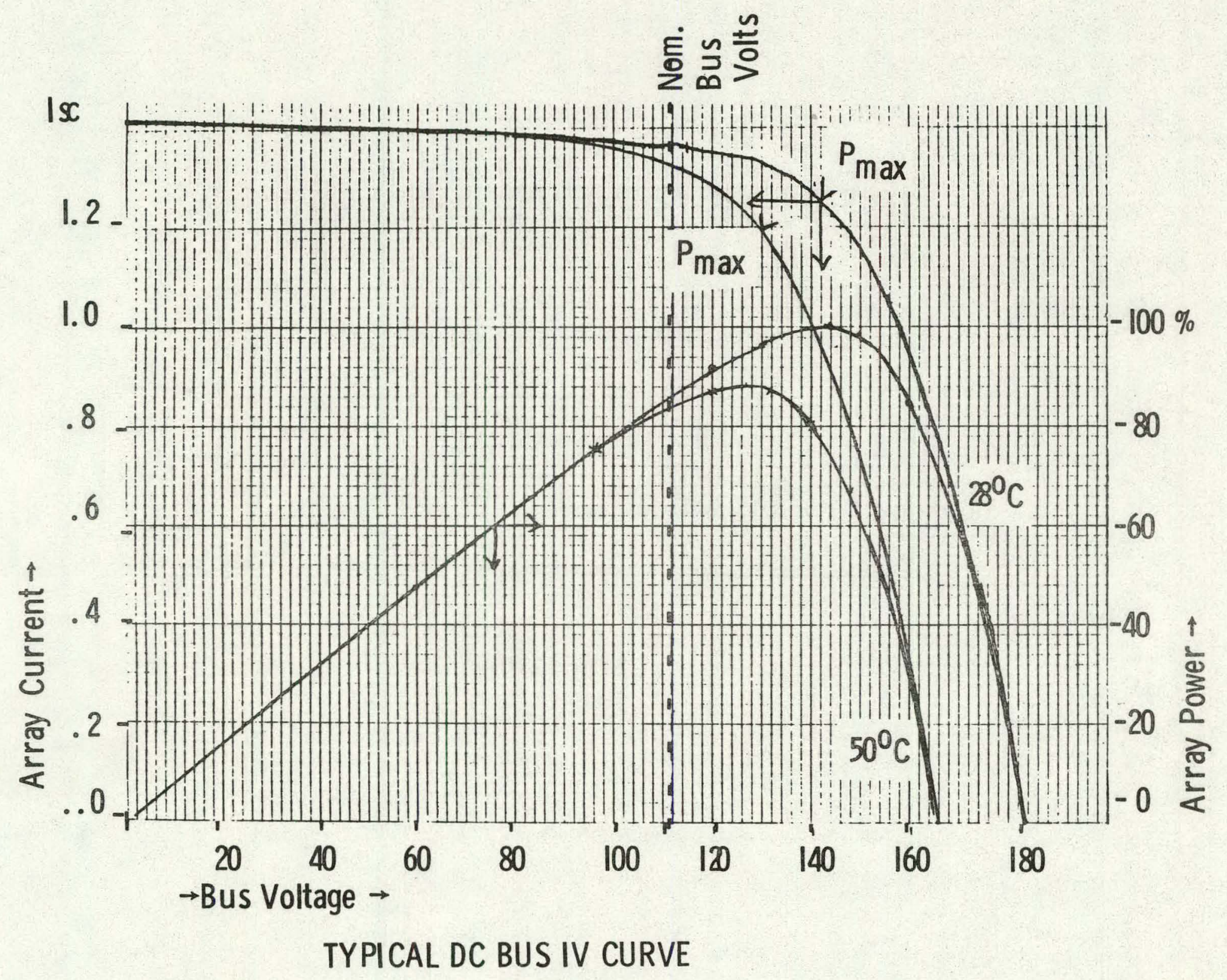




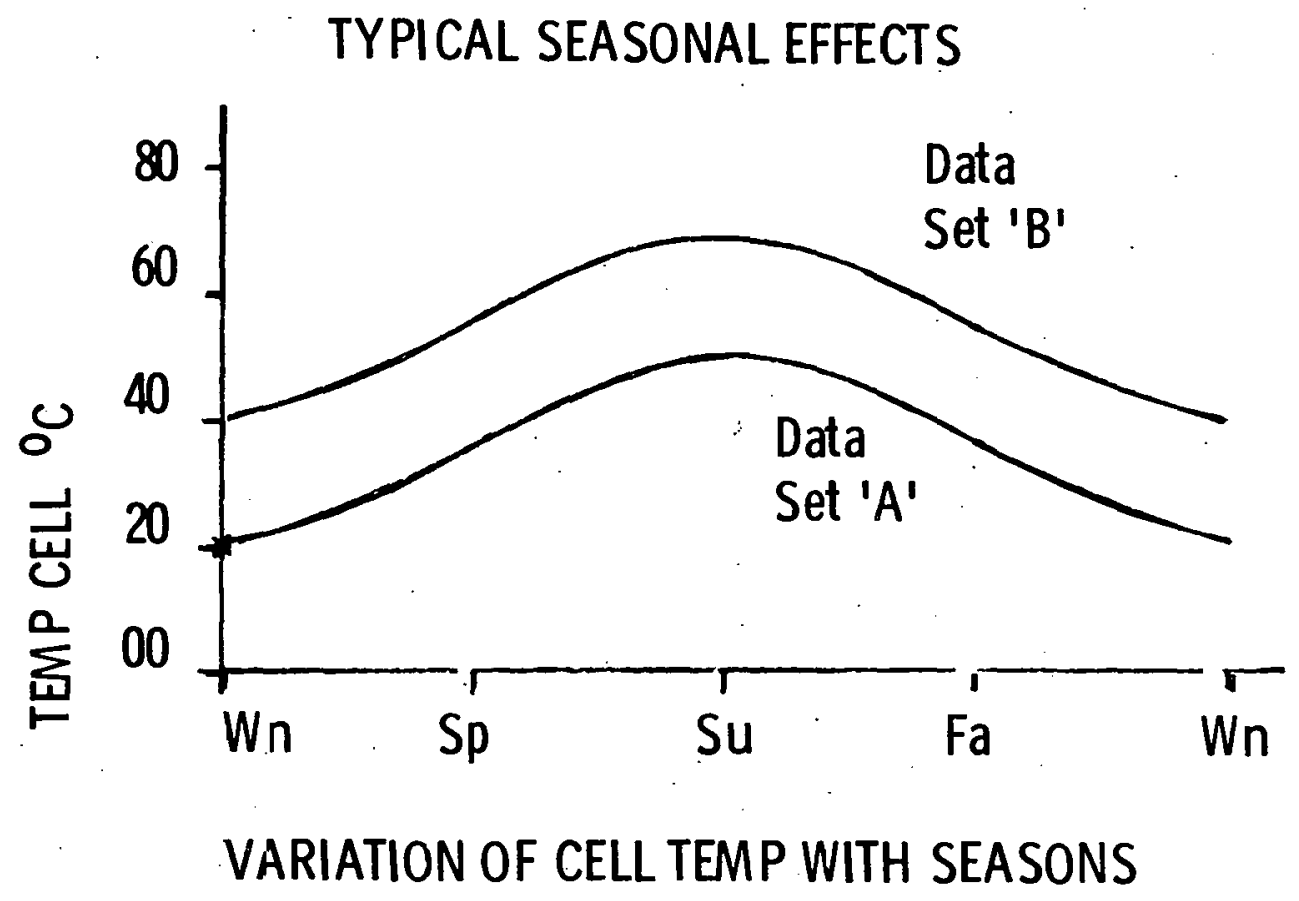




\section{Computer program \\ Data Set}

\subsection{Kw Array}

2308 AH Battery (100 A Rate)

172 AH Annual daily avg array current

$154 \mathrm{AH} "$ " "Load Current

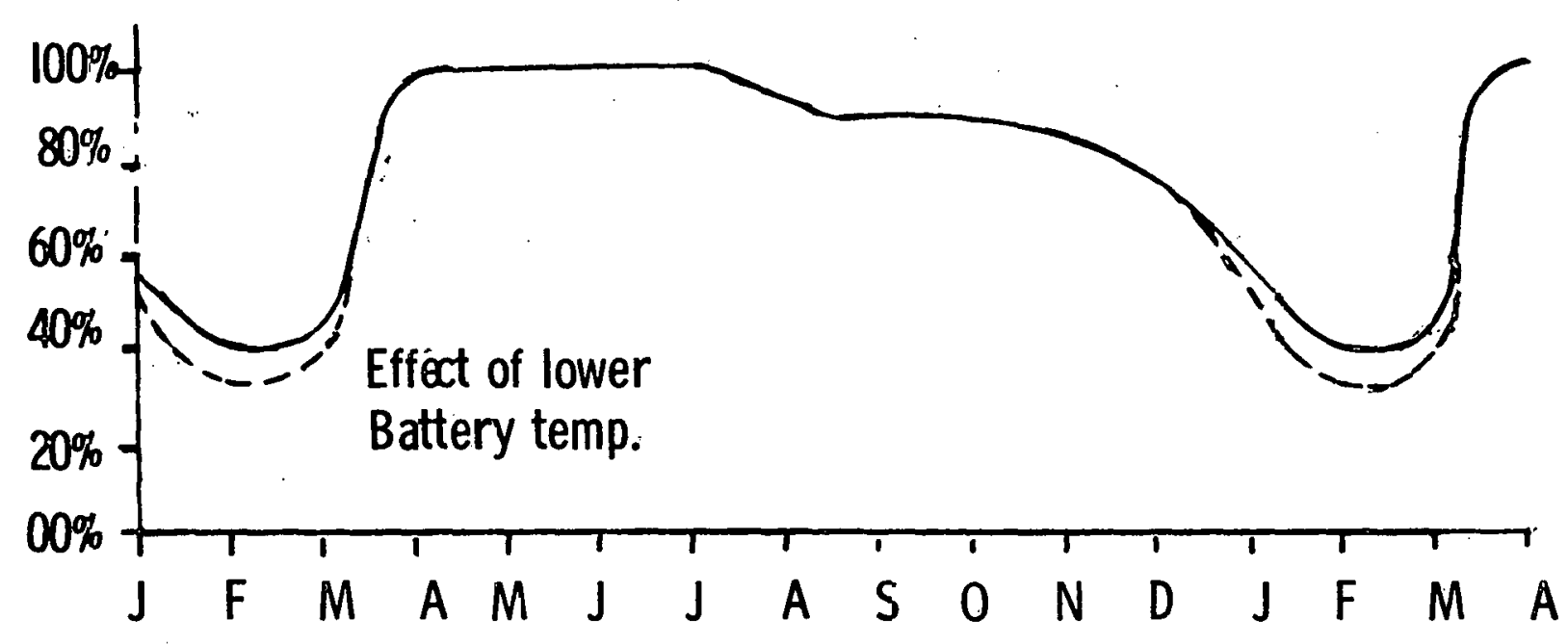

BATTERY STATE OF CHARGE (SOC)

SEASONAL VARIATION 


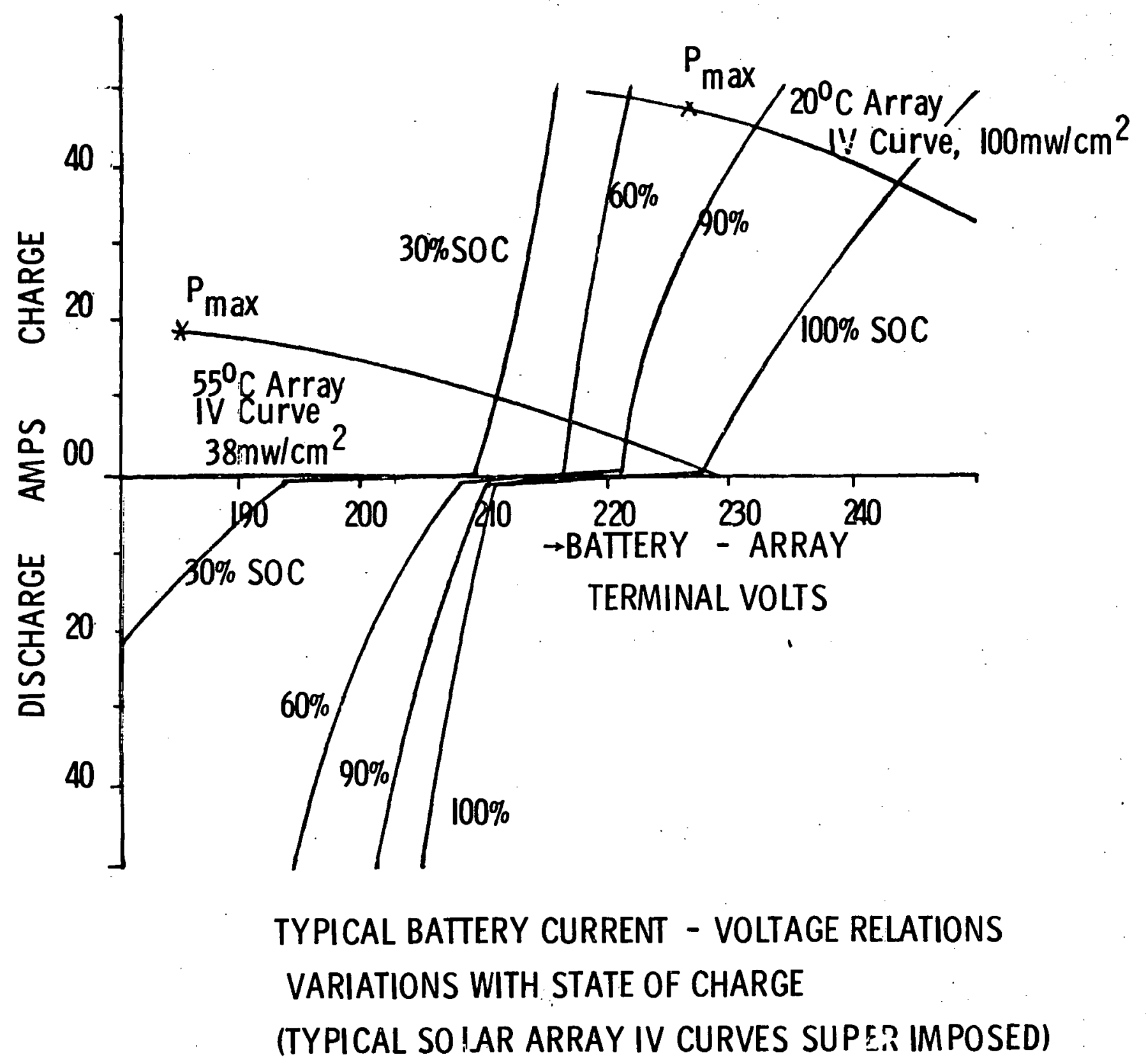


TECHNICAL DESIGN FACTORS IN SMALL POWER INVERTERS

- BASIC DESIGN REQUIREMENTS NOT A FUNCTION OF SIZE , BUT APPLICATION

- IF STAND ALONE APPLICATION, INVERTER MUST :

Be self Commutded

Be sized to accomodate load, including providing motor starting currents

Be able to supply reactive load currents

Provide voltage regulation to accomodate changes in the input $D C$ levels

Generate output voltage with harmonics content limited to the Load THD reqs

- IF OPERATED IN UTILITY UNE CONNECTED MODE, INVERTER MUST :

Incorporate paver level control. Inverter sees utility as essentially a zero impedance load to hasic frequency voltages Power level must be sat by a control function , to be compatible with power source capability.

Provide for reactive power capdility compatible with the power level control mode chosen.

Limit hamonic content of current to values acceptale to utility

Provide acceptable power factor output 


\section{DESIGN FACTORS CONT :}

- PROVISION FOR EQUIPMENT AND PERSONNEL SAFETY MUST BE MADE

- DESIRABLE FEATURES FOR EITHIER MODE OF OPERATION INCLUDE :

Low losæs (high efficiency) during the period when solar array cots are high Low no-load losss if inverter is to be operated for long periods at low loadings. 
RESPONSE TO DESIGN REQUIREMENTS IN ABACUS' IO KVA INVERTER

- DESIGNED FOR GENERAL APPLICATION. HENCE CAN OPERATE IN EITHER STAND ALONE OR UTILITY MODE

- EFFICIENCY ABOUT 90\% FOR LOADS FROM 35\% TO FULL LOAD AT NOM VOLTAGE

- NO LOAD LOSSES LIMITED TO $2 \%$ to $3 \%$ OF FULL LOAD FOR RATED INPUT VOLTAGE

- INCORPORATES POWER LEVEL CONTROL TO SET POWER TRANSFERRED TO THE UTILITY AT.THE ARRAY MAXIMUM POWER CAPABILITY

- OUTPUT CURRENT TO UTILITY IS KEPT IN PHASE WITH UTILITY VOLTAGE. HOWEVER INVERTER IS CAPABLE OF SUPPLYING REACTIVE CURRENT IN EITHER MODE

- OUTPUT CONTACTOR CONTROLLER AND INVERTER BRIDGE DRIVE CONTROLS ARE DESIGNED TO PROTECT AND INTERRUPT SERVICE FOR OUT OF TOLERA NCE CONDITIONS' 


\section{EFFCIENCY AND LOW NO-LOAD LOSS DESIGN}

- USE TRANSITOR OUTPUT POWER STAGES' OPERATE NON SATURATED

- USE PROM STORED PULSE PATTERN FOR WAVE SYNTHESIS. ELIMINATES HARMONICS IN SINGLE BRIDGE UP TO THE ELEVENTH

- USE DUAL BRIDGE WITH DIFFERENT PULSE PATTERNS TO ELIMINATE HARMONICS UP TO THE NINETEENTH

- HIGHER HARMONIC OUTPUT REDUCE FLTER REACTIVE 'OOLT AMPS , WITH ASSOCIATED REDUCED LOSSES AT NO MO LOAD

- ÓPERATE OUTPUT TRANSFORMER AT LOW FLUX DENSITY OF IO KILOGAUSS FOR REDUCED CORE LOSSES 
POWER LEVEL CONTROL (IN UTILITY MODE)

- basic POWER leVEl CONTROL MEthod IS tO SET the MAGNITUDE OF the INVERTER OUTPUT CURRENT TO THE UTILITY IN RESPONSE TO A COMMAND FROM THE POWER SYSTEM CONTROLLER (MAX POWER TRACKER)

- THE PHASE LOOP CONTROL MAINTAINS THE OUTPUT CURRENT IN PHASE WITH THE UTILITY VOLTAGE OR AT UNITY POWER FACTOR

- THE CURRENT AND PHASE LOCK CONTROLS ARE INDEPENDENT CLOSED LOOP CIRCUITS BUT INTERACTIVE

- THE CURRENT LEVEL COMMAND IS DERIVED FROM ANALYSIS OF APONER DITHER SIGNAL AND ESSENTIALLY CAUSES THE INVERTER TO LOAD THE ARRAY TO A TARGET TERMINAL VOLTAGE COMPATIBLE WITH ARRAY MAX POWER 
INVERTER CIRCUIT PROTECTION

- LOAD INTERFACE PROTECTION IS PROVIDED BY OPENING OUTPUT CONTACTORS FOR OUT OF TOLERANCE CONDITIONS OF UV I OV ON THE AC LINE

- IN THE UTILITY MODE, CLOSURE OF THE OUTPUT CONTACTOR IS INHIBITED BY OUT OF LIMIT CONDITIONS AT THE INVERTER I LINE VOLTAGE I PHASE COMPARISON

- POINER TO THE BRIDGE DRIVE CIRCUITS LOGIC IS INTERRUPTED BY TRANSISTOR SWITCH FOR OUT OF TOLERANCE VOLTAGE CONDITIONS AT THE INVERTER DC INPUT .

- INVERTER OUTPUT CURRENT IS LIMITED TO SAFE LEVELS BY A CURRENT MONITOR CIRCUIT WHICH OVERRIDES ALL OTHER SIGNALS IF CURRENT REACHES THE PRE SET CURRENT LIMIT 


\section{INVERTER VOLTAGE AND CURRENT TRACES}

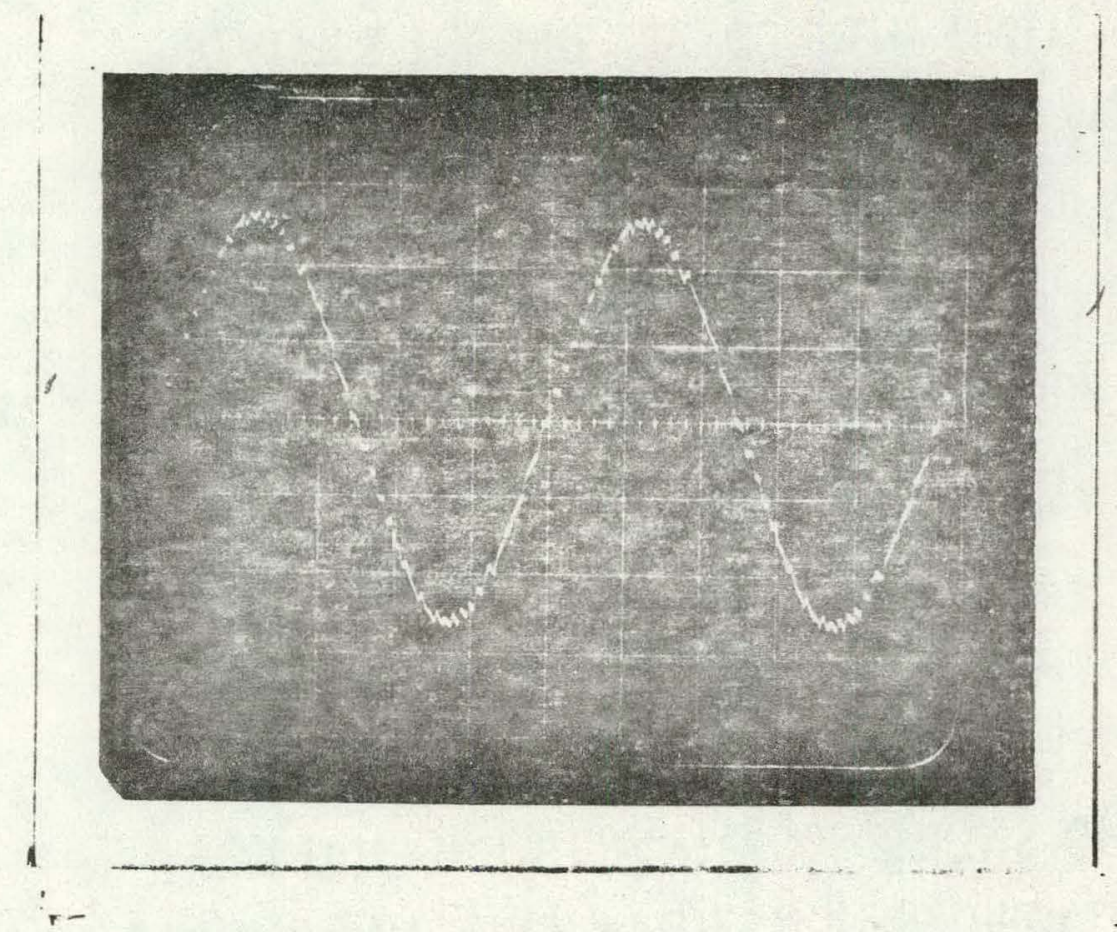

Inverter voltage at $10 \mathrm{kw}$ in sand allone mode

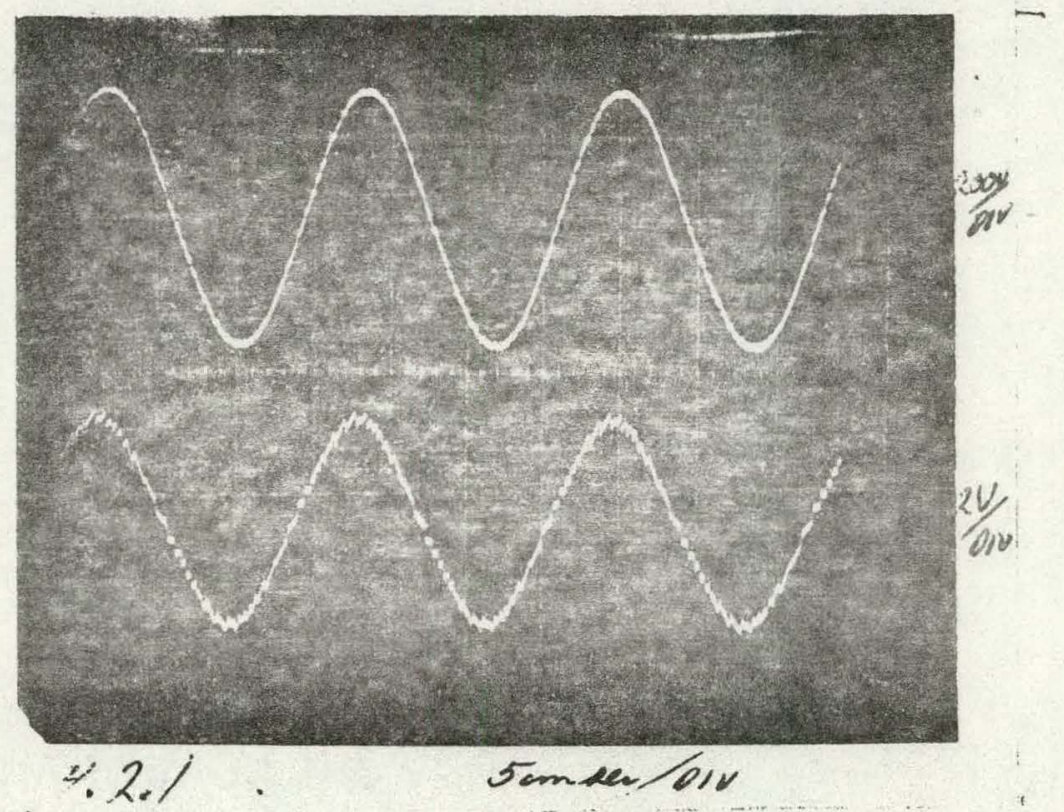

Line voltage and inverter current at 10 kva to Utility 


\section{PHASE LOCK ACQUISITION}
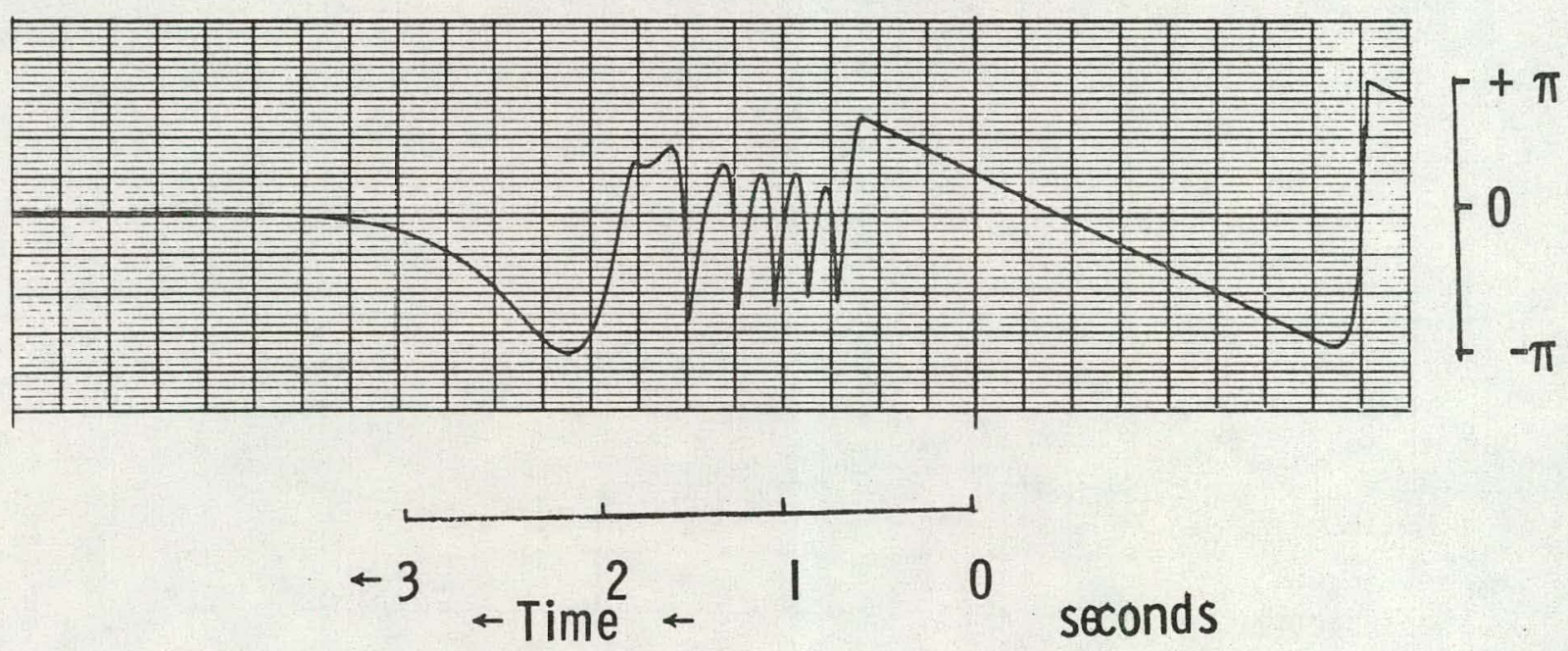

Torque Angle Trace : Angle between Inverter internal voltage \& Line V 
LOSS OF PHASE LOCK AT 10\% LOAD

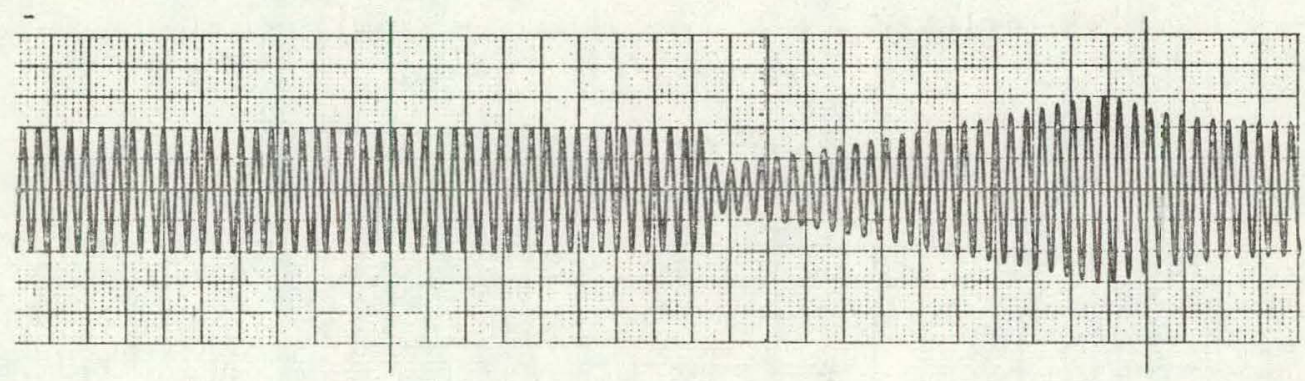

Inverter voltage $240 \mathrm{~V}$ RMS

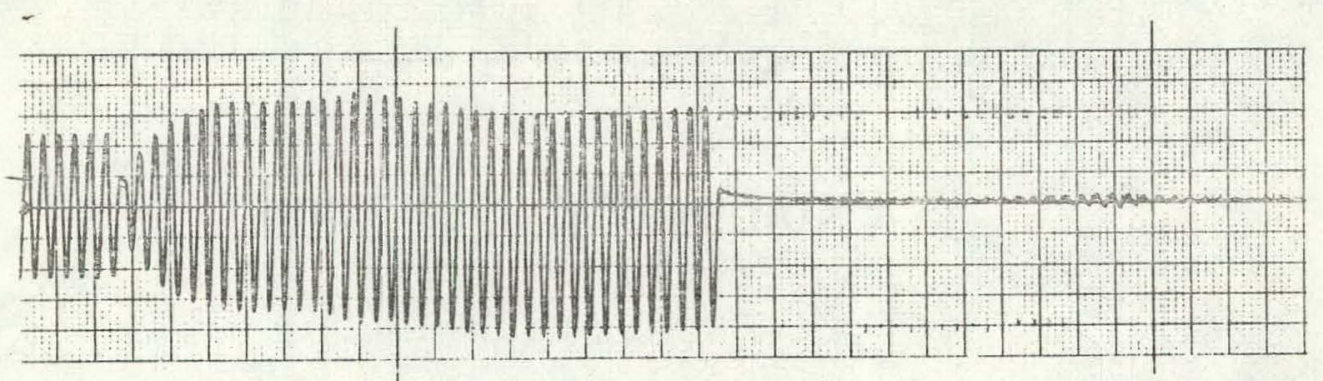

Inverter current $4 \mathrm{~A}$ RMS 
FIELD TEST at LEWIS RES CNTR

INVERTER OPS - UTILITY MODE - SOLAR ARRAY POWERED
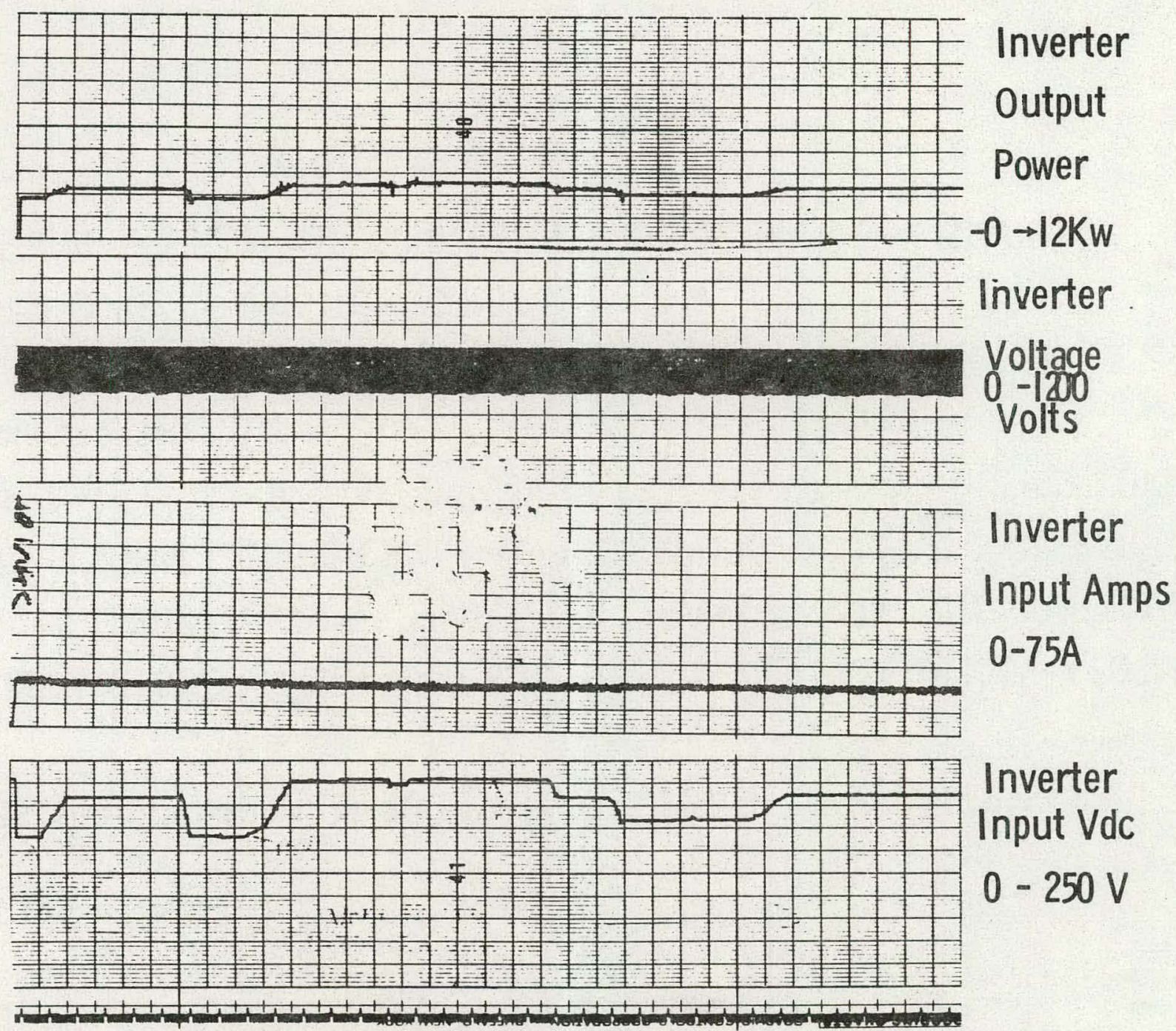

Inverter Input Vdc $0-250 \mathrm{~V}$ Time scale $60 \quad 4020 \quad 0 \quad \mathrm{sec}$

Vary PSC command to regulde SA at different voltage levels 
TECHNICAL APPROACH TO LOWER COST POWER CONDITIONER

- TARGET CALLS FOR \$200 / WATT COST FOR SINGLE P.HASE 10 KVA X FORMER

- ABACUS DESIGN COMBINES SIMPLE SCR / TRANS FORMER WITH CONTROLLED FERRO RESONANT TRANSFORMER TO ACCOMPLISH DC TO AC CONVERSION

- OUTPUT VOLTAGE PHASE SET BY SCR INVERTER TO MAINTAIN OUTPUT CURRENT IN PHASE WITH UTILITY

- OUTPUT POWER LEVEL SET BY CONTROLLED FERRO RESONANT X FORMER BY OUTPUT CURRENT AMPLITUDE CONTROL

- FILTERING IS ACCOMPLISHED BY THE FERRO RESONANT TRANSFORMER 


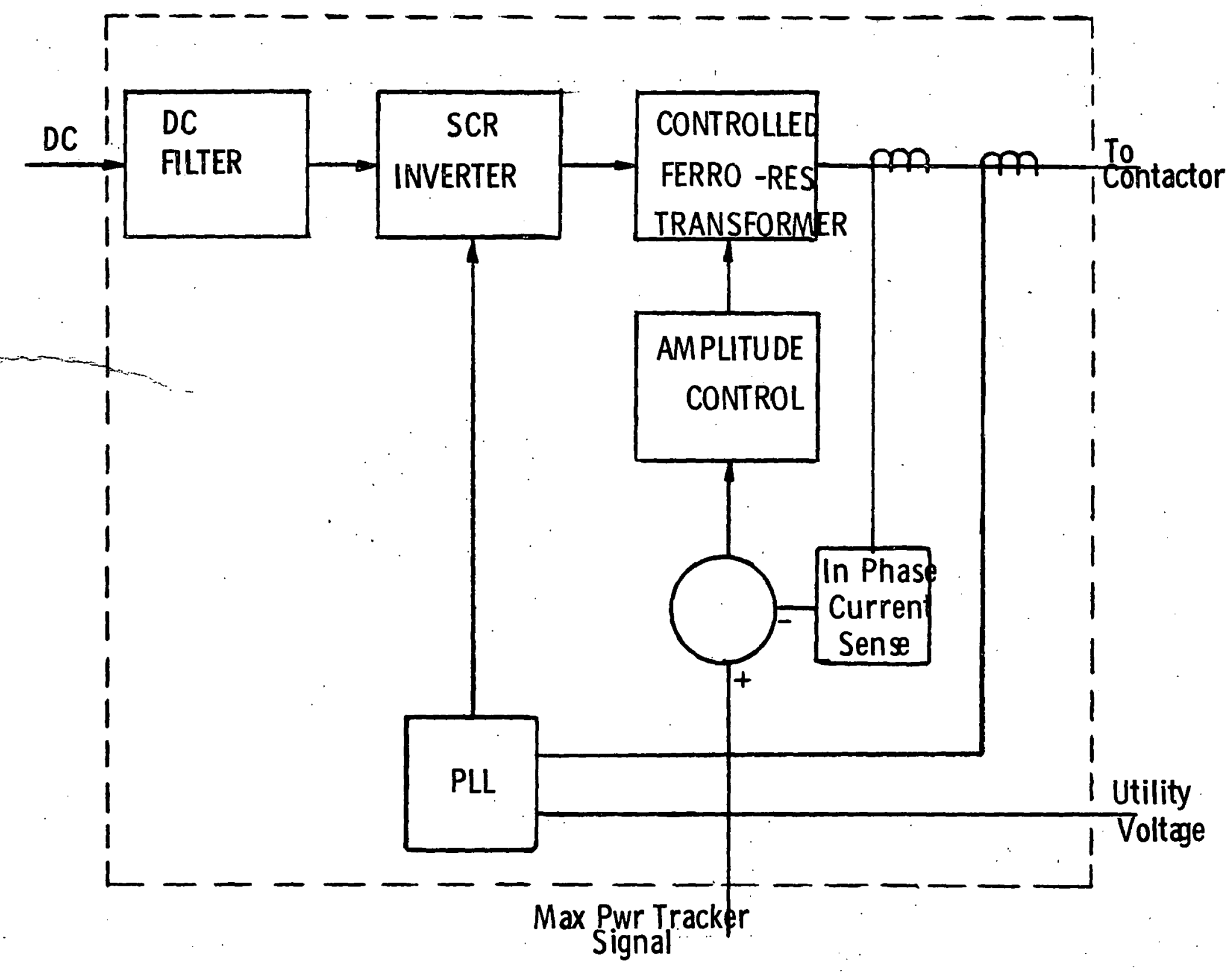

ADVANCED 10 KVa INVERTER CONCEPT 


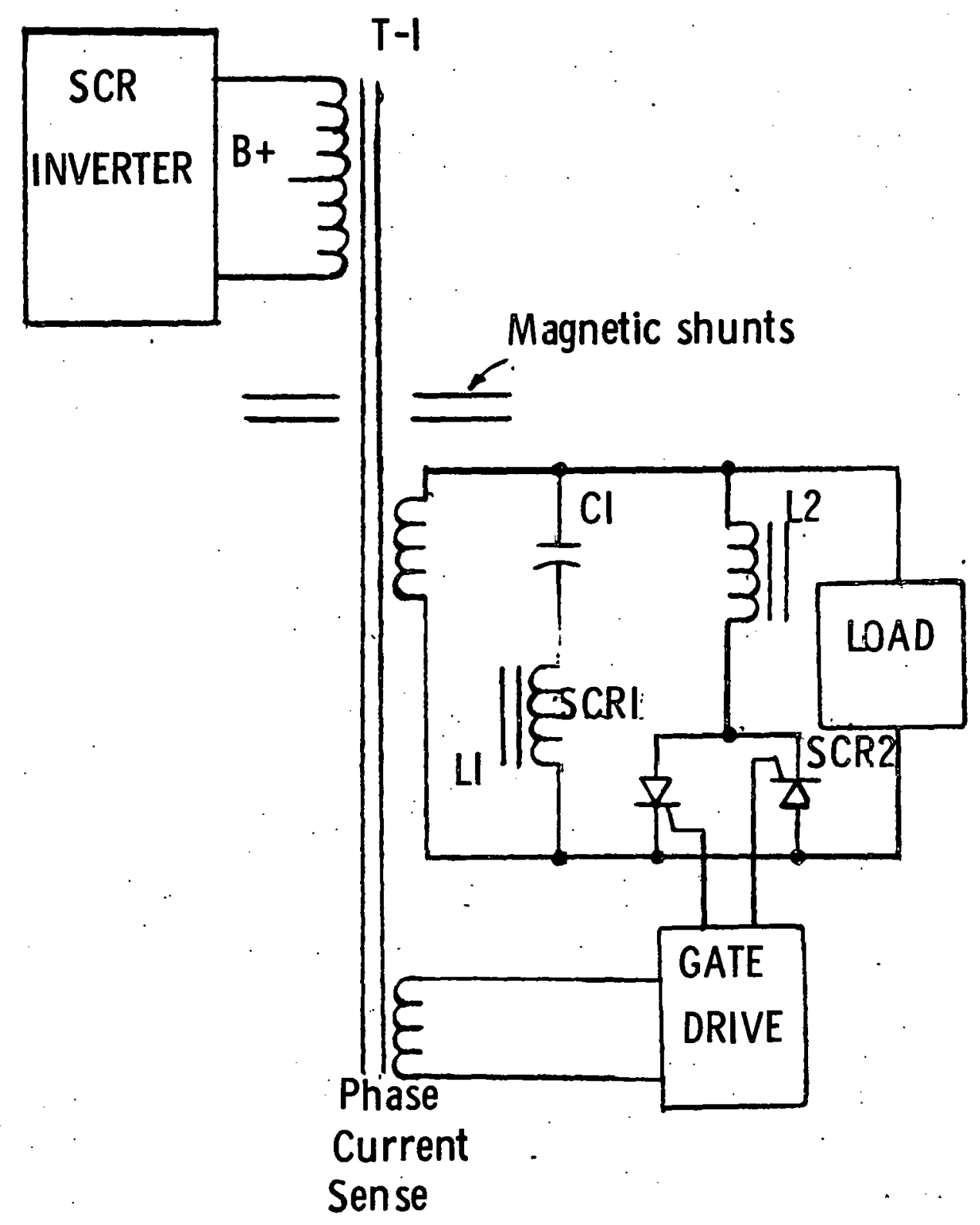

CONTROLLED FERRO RESONANT TRANSFORMER 


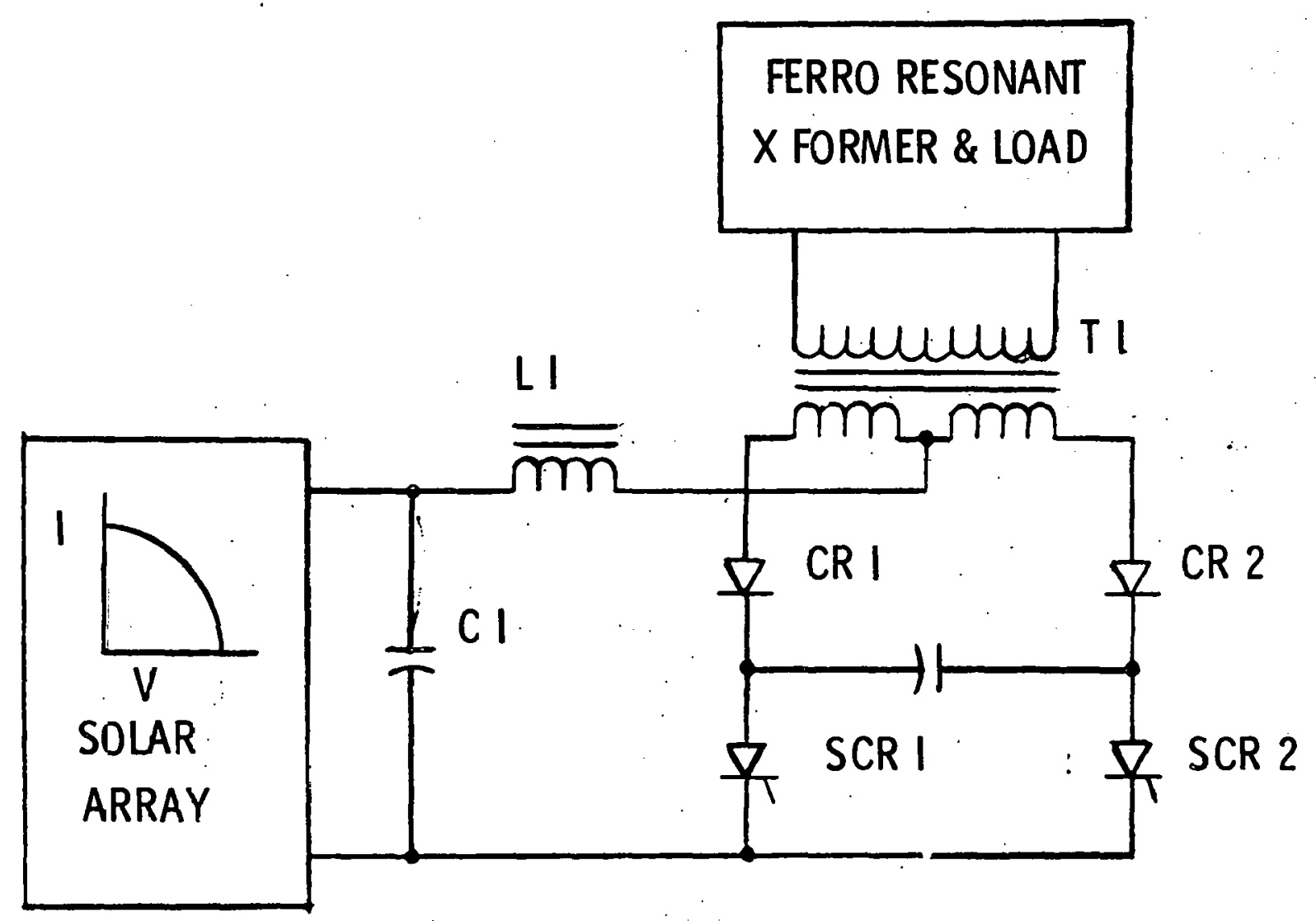

SCHEMATIC : DIAGRAM CURRENT FED SCR INVERTER 
PV - PWR CONDITIONING DEVELOPMENT : BACKGROUND

- SURVEY EARLY IN PROGRAM INDICATED that THERE WERE NO " OFF THE SHELF " HARDWARE SUITABLE FOR PV APPLICATIONS

- early PV APPLICATIONS WÉre MOSTLY DC, heNCE DID NOT REQ' PWR COND'

- PLANNING ACTI VITY BY SANDIA : MIT : AND LERC DEFNED NEED FOR ORDERLY DEVELOPMENT OF GENERAL PURPOSE POWER CONDITIONERS, CUSTOMIZED FOR P.V APPUCATIONS.

- ORDER FOR DEVELOPMENT OF SMALL IO KVA PV INVERTER PLACED BY LeRC WITH ABACUS CONTROLS. FOLLOW ON UNIT MODIFED BY SANDIA CONTRACT FOR MAX PWR TRACK CAPABILITY' CONTRACT STRESSED PERFORMANCE

- DEVELOPMENT OF 50 KVA PV INVERTER PLACED BY SANDIA WITH WESTINGHOUSE UNIT ALSO STRESSED PERFORMANCE 
PV - PWR. CONDITIONING CONTINUED:

- DEVELOPMENT OF ADVANCED 10 KVA INVERTER PLACED BY SANDIA WITH ABACUS . STRESSED COST GOALS

- DEVELOPMENT OF 60 KVA INVERTER PLACED BY MERADCOM WITH DECC: INCORPORATED MAX PWR TRACKING

- DEVELOPMENT OF FAMIL.Y OF SMALL ( 0.5 TO $3 \mathrm{KW}$ ) INVERTERS BY

- INDEPENDENT DEVELOPMENT OF SMALL INVERTERS STRESSING LOW LOSS OPERATION MADE BY SMALL FRMS 


\section{TECHNICAL AREAS - REQUIREMENTS}

- DEVELOPMENT OF INVERTER SPECIFCATIONS BY SERI

- EFFCIENCY - GOALS - HOW TO MEASURE

- INPUT VOLTAGE RANGES - DIFFERENT FOR BATTERY STABAUZED BUS

- $\quad$ OUTPUT VOLTAGE LMITS

- $\quad$ FREQUENCY STABILTY

- OUTPUT HARMONIC CONTENT - HOW MEASURED 
WHAT MARKETS TO ADDRESS

- EARLY STAGE OF PV INCUSTRY MAY PROMOTE SMALL INVERTERS AS FRST TO BE ECONOMICALLY FEASIBLE. SPEC TOLERANCES MAY BE LOOSE.

- MEDIUM SIZE UNITS MAY BE FEASIBLE FOR REMOTE VILLAGES OR COTTAGE INDUSTRY

- INTERFACE WITH UTIUTY NETWORK PROBABLY WILL GENERATE MOST RIGORO!'S SPECIFCATIONS 
DC APPLICATIONS

- IMPRACTICAL TO USE SOLAR ARRAY OUTPUT DIRECT IN MOST APPLCATIONS BECAUSE OF WIDE VARIATION OF VOLTAGE WITH LOAD

- BATTERY SERVES tO STABILIZE BUS VOLTAGE

- VOLTAGE REGULATION MAY BE LMITED TO PROTECTING THE BATTERY FROM EXCESSIVE CHARGE

- MAX POWER TRACKING COULD INCREASE POWER OUTPUT BUT MAY NOT BE ECONOMIC

- DEVELOPMENT OF DC EQUIPMENT FOR DOMESTIC USES MAY BE NEEDED IB ORDER TO FULLY EXPLOIT PV POWER SOURCE' 


\section{COST CONSIDERATIONS IN PV SYSTEMS}

- CURRENT COSTS FOR SMALL PV SYSTEMS ARE ABOUT \$30/WATT.

Costs about equally divided between modules and balance of system (BOS)

- COST EFFECTIVE APPLICATIONS JUSTIFED FOR ONLY A LMITED FEW CASES

Little incentive for sophisticated systems. However, improved efficiency can sometimes pay off in reduced array requirements. Example: A 10\% increase in BOS efficiency can reduce aray costs $\$ 1.50$ / Watt at current array co\$s.

- WHEN ARRAY COSTS ARE REDUCED TO THE DOE PROGRAM GOALS OF \$I I WATT BOS COSTS CAN BE THE IMPEDIMENT TO COMMERCIAL FEASIBILITY.

- TRADE OFFS, BASED ON ELEMENT COSTS MAYBE USED TO OPTIMIZE SYSTEM COSTS FOR EQUAL PERFORMANCE 
Working Group 1

POWER CONDITIONING FOR PHOTOVOLTAICS 
Group Report

Roy Pickrell; Leader.

NASA Lewis Research Center

Cleveland; $\mathrm{OH}$

\section{INTRODUCTIION}

The overall DOE goal for photovoltaics is to promote the implementation of photovoltaics as a viable alternative energy source. The power conditioner is a key element in a photovoltaic system. Thus, to achieve the DOE goals, power conditioners must be aeveloped which meet certain performance standards and which can be mass produced at sufficiently low cost. The purpose of this working group was to assess the current technology in power conditioning for photovoltaic systems, to, identify operational requirements, to identify problem areas, and to obtain inputs which will be useful to DOE in planing future activities. The working group included 48 persons from government, private industry, utilities, and universities. The detailed breakdown was as follows:

Government

Universities and Frivate Labs

Solar Array Manufacturers

Power Conditioning Manufacturers

Potential Customers

Utilities

The chairman of the group was R. Pickrell of NASA Lewis Research Center. Fanel members incluäed:
George O'Sullivan
Abacus Controls
Ervin Lyon
MIT Lincoln Labs
Frank Goodman
L. A. Dept. of Water and Power



E. Landsman
MIT Lincoln Labs
Hans Meyer
windworks

\section{Discussion Topics}

The major topics of discussion were projected costs, power quality, and the direction for future development activities. other topics briefly discussed included possible size limitations of photovoltaic systemis and general safety issues for dispersed power systems. The follnwing is a synopcic of the discussions.

a) Frojected Costs - Consumer cost projections by several contractors who are developing power conditioning units for photovoltaic systems were presented. All were within the DOE cost goal of $\$ 200 / \mathrm{kW}$ in production quantities of several thousand units per year. The question was raised whether or not a real market for a residential type $10 \mathrm{kVA}$ unit would exist at this cost, i.e., is the residential market a viable application? It was noted that a $\$ 1600 / \mathrm{kw}$ installed total system cost is viable if the value of power produced is $5-7 \mathrm{k} / \mathrm{kWh}$. Within that context $\$ 200 / \mathrm{kW}$ for the power conditioner is a reasonable fraction of the total cost. It was also stated that the $\$ 500 / \mathrm{kW}$ production goals for PV modules by 1986 will be met if annual production rate is $50 \mathrm{MW} / \mathrm{Yr}$, corresponding to $5000-6000$ houses per year.

The validity of the $\$ 200 / \mathrm{kw}$ projected costs was questioned by some, but it was supported by firm price quotations for all materials and labor estimates based on current labor and burden rates. One manufacturer gave the following approximate cost breakdown for his dual bridge transistorized $10 \mathrm{kVA}$ unit, including labor: 
Trans istors

Sheet Metal

Magnetics

Switchgear

Logic, Low-Level Electronics, and Miscellaneous
448

268

138

138

48

Another vendor who manufactures line commutated inverter

systems in this power range itemized his costs as follows:

Filters

Power Train

Control

Contactors

Cabinet

Miscellaneous

Labor
398

268

98

58

$5 \%$

78

98

b) Power Quality - Discussion of this topic began with attempting to define acceptable values of harmonic distortion and power factor. One participant pointed out that the utility line impedance should be defined in order to establish a power quality standard: Another suggested that harmonic content of the current injected into the utility line should be the basis for a power quality definition. An oscilloscope trace of the current from a $10 \mathrm{kVA}$ inverter injected into the utility line was presented; the measured current THD was 3.68 for full load operation.

The Europeans have developed a specification identified as UDE which addresses the question of injected noise, but no comparable U. S. standard exists. One participant pointed out that 
insistence on power quality standards for photovoltaics where none exist could unduly penalize power conditioner costs. However, strong concern was expressed by the utility representatives on the potential problems of noise injected onto the utility lines. by customers, no matter what the source. In fact, they indicated a feeling of responsibility to protect other customers from excessive injected noise and stated that they were in the process of establishing a concensus relative to that problem.

c) Direction of Future Development Activities - The feasibility of achieving further cost reauctions to produce photovoltaic power conditioners in the $10 \mathrm{kVA}$ range which could sell for $\$ 100 / \mathrm{kW}$ was discussed. New components such as gate turn off SCRs and low cost transistors with greater power handing capability may in the future bring about significant cost reductions. Amorphou magnetic materials may make it possible to reduce the cost of transformers and, inductors. Circuit development activity should be geared toward innovative designs which take advantage of available circuit components. In particular, the use of a high frequency link to eliminate the heavy, costly $60 \mathrm{~Hz}$ magnetic components is a technique worthy of renewed investigation. A development effort for lower cost DC switchgear was also encouraged. An issue which needs to be resolved is the safety and stability of a number of dispersed power systems connected to the utility grid, and the effects of harmonics in such systems.

\section{d) Other Topics iniscussed}

1) The subject of power conditioning for dc systems was aiscussed briefly. It was agreed that, as a minimum, some 
form of bus voltage regulation would be required to limit battery charge voltages.

2) The efficiencies of power conditioners developed for photovoltaics are typically $90 \%$ or better for 50 to 100 . percent load. One manufacturer reported tare power losses of 5 to 7 percent of full load for a $10 \mathrm{kVA}$ SCR bridge device with a controlled ferroresonant transformer; he compared this to 2 percent for his 10 kVA dual bridge transistor unit.

3) The question was raised whether $10 \mathrm{kVA}$ is the only size required for residential applications. One manufacturer plans to develop a low cost proauct line which includes 6 , 10, and is kVA sizes.

4) A chart (attached to this summary) was presented showing the results of a preliminary dc cable size/cost/loss analysis per formed by GE for a variety of power levels with dc bus voltage as a parameter. The results would appear to indicate that, in order to limit the dc cable power losses to a few percent it is necessary, for systems of a size greater than about $100 \mathrm{kw}$, to either

a) operate at dc voltages greater than those at which most present arrays are designed to operate, or

b) break up the array into modules with separate inverters for each module. However, the critical system size is several MW if one considers energy losses rather than power losses in the dc cable.

Although present arrays are tested at 1500 volts, they are operated at only a few hundred volts at most. For comparison it was noted that fuel cell power conditioning units operate at 265 volts, and a $4.8 \mathrm{MW}$ unit for battery systems operates 
at 3400 volts.

5) There are currentiy no requirements for isolation of a photovoltaic (or other alternative energy) system from the utility although many proposed systems include an isolation transformer. Similarly, there are no requirements for grounding arrays. Grounding provisions similar to those for battery systems might be suitable, except that photovoltaic arrays have the added disadvantage of being located outdoors and thus must also be protected from lightning strikes.

\section{CONCLUSIONS AND RECOMMENDATIONS}

Future development activities for power conditioners for photovoltaic systems should be directed toward innovative designs which reduce the cost, with production goals of $\$ 100 / \mathrm{kW}$ or less for the $10 \mathrm{kVA}$ size. These designs should minimize raw materials and take advantage of available, low cost components. New developments in solid state devices and magnetic materials should be noted, particularly as other markets bring about cost reductions. The possibility of initiating a program to develop low cost dc switchgear should be considered. Finally, a computer study should be initiated to analyze the mutual interaction of a large number of residential photovoltaic or other dispersed power systems connecled to a ut111ty grid. Such problems as stability, harmonics, cloud cover (for photovoltaic systems), and safety should be included in the analysis. This should be followed by an applications experiment, e.g., a housing development with photovoltaic power systems connected in parallel with the utility, to obtain data and compare it to the computer analysis. 
Working Group 2

POWER CONDITIONING FOR FUEL CELLS AND BATTERY STORAGE 


\section{WORKING GROUP ON POWER CONDITIONING FOR FUEL CELLS AND BATTERIES \\ Paul F. Pittman, Group Leader}

\section{Summary}

\section{Introduction}

The purpose of the group was to discuss the following topics In regard to power conditioning for fuel cell and battery energy systems:

- Assess current and future. technology

- Identify operational requirements

- Identify mass production and marketing requirements

- Suggest effective ways to stimulate development

The discussion perlod allocated for the work of the group was subdivided Into four parts, and a perfod of time was devoted to discussion of each of the major topics 11sted. In the case of some, the discussion was quite detalled, while others were omitted entirely elther because they were irrelevant to the work of the group, or because there was no time for their consideration.

The group was quite diverse, conprising twenty people including 13 from industry, four from government, and three from ut1lities. The 13 from Industry Included battery vendors, fuel cell vendors, power conditfoner vendors, and users of such equipment. Because of the diverse backgrounds of the group members, a stimularing and effective dialog was set up between energy source vendors and power conditioner vendors which was of benefit to all work1ng group attendees. 


\section{Discussion Topics}

A few basic assumptions were made to lay the ground work for the discussion of the group and to limit the range of the discussion to one commensurate with the avallable time. The time period considered for the discussion ranged from the present to the year 2000. When projections were made, the discrete points of the present, 1985 and 2000 were used where appropriate. In addition, in the case of battery systems, only battery energy storage systems were considered. Hybrid systems which Included batteries together with alternative energy sources, such as photovoltalc array, were excluded.

\subsection{Technology Assessment}

It was determined that the basic power conditioning technologies needed for battery and fuel cell systems are quite similar. The equipments needed differ at the Input or DC Interface because of the differing characteristics of the two types of energy sources, while the output or AC interfaces are quite similar. A major difference in performance is the need for bidirectional power flow in the battery power conditioner which is not required for the fuel cell power conditioner.

For the purposes of the discussion of this group, the following ranges of operating power level were established:

Batterles $2.5 \mathrm{MW}$ ro $100 \mathrm{MW}$

Fuel Cells $\quad 50 \mathrm{~kW}$ to $100 \mathrm{MW}$

Present technology is best described in terms of existing programs as follows: 
2.1.1 Batteries - The largest battery program now in progress is the BEST facility which includes construction of a developmental lead acld utflity load levelling battery facllity capable of $2.5 \mathrm{MW}$ at a 5 hour rate. A new, large commerclalization program about to be started is the SBEED program which will also be a ut1lity load levelling battery which will provide $20 \mathrm{MW}$ at a five hour rate.

Both Iine-commutated and force-commutated inverters have been used for such systems, and both are under consideration for future applications. The group could not reach a concensus on this polnt because the cholce is largely a matter of personal preference at this time. Each system has its performance advantages and disadvancages as well as development and production costs, all of which must be weighed for each application.

At present, only lead actd battery systems are avallable for system development and commerclalization, but many other systems are In the R\&D stage and should begin to become avallable for system development by 1985. Included are $\mathrm{ZnCl}_{2}, \mathrm{ZnBr}, \mathrm{N} 1 \mathrm{H}, \mathrm{LIFeS}, \mathrm{NaS}$, and Redox.Although the power conditioning needed for these advanced systems will be basically the same as that used for lead acld systems, some have certain special requirements which should be studied at this time so the necessary equipment w11l be avallable when needed.

The circult breakers used for large DC systems are the largest avallable. A 5000A breaker made by Slemens 18 belng used for the BEST facility, but larger units are needed and malntanence is a problem. Westinghouse has an EPRI contract to develop a $2500 \mathrm{~A}$ breaker, but it works In confunction with the power conditioner and is not an in-1ine interrupter. 
A consideration in breaker design is the surge current capability of the energy source. The fuel cell is current limited, but can produce a short, high amplitude pulse of current. Conventional lead acid batteries can produce surge currents 10 to 20 times rated, while newer battery systems produce surge currents only two to three times rated.

Analytical models of presently used lead acid batteries needed to describe both transient and steady state battery performance are hard to obtain. If better models were available, better power conditioner design could be performed, and equipment testing would be simplified. In general, the power conditioner can be designed to provide the kind of performance desired if the performance requirements are made known. Needed are requirements for charge and discharge as well as startup, standby, and shutdown.

The battery for the BEST facility includes 500 cells in series yielding 1000v. Equilization is accomplished by overcharging the battery causing the cells to gas. The resulting hydrogen is then driven from the battery building by a fan. From the standpoint of the power conditioner, the number of series cells and thus the resulting DC output voltage should be higher, in the order of 2000 to $3000 \mathrm{~V}$. The impact of such a change on battery cost and performance should be investigated.

The present battery module size is $5000 \mathrm{~A}$ leading to a $5 \mathrm{MW}$ module. The size is determined by a number of constraints including the size of the largest DC breaker avallable. It is possible that this size is optimum, but further work should be done to verify this or to recommend a more optimum module size.

\subsubsection{Fuel Cells - The state of the art in fuel cells at present} can be characterized by the major Installations which are a unit at Consolidated Edison rated at $4.8 \mathrm{MW}$, and several smaller units rated at $40 \mathrm{~kW}$ to $120 \mathrm{~kW}$. 
Owing to a shortage of time, the fuel cell technology assessment discussion was cut short.

\subsection{Operational Requirements}

The following operational requirements were discussed.

Power Qual1ty - The quality of power required by the ut1litles has not yet been defined, but a number of EPRI programs include an investigation of factors relaring to 1t. A partal list of these is as follows: RP 1024-1, RP 841-1, RP 390, and RP 840. A contributing document is the IEEE Guide for Harmonic Control and Reactive Compensation of Static Power Converters.

Rellabllity - Avallabllity is one measure often used. In DC transmission systems, values for Av exceed $96 \%$. For battery and fuel cell systems, the avallability goal should be a minfmum of $95 \%$. The predicted availability for SBEED $1899 \%$

The FAA has deployed 90 UPS systems at alrport control towers throughout the country. After two years of expexience, the observed mtbf 1s in excess of $17000 \mathrm{hrs}$.

When equipments are destgned, analyses of the affects of single point fallures should be conducted. In present large systems, power transformers present a common fallure problem. The fallure of a large transformer usually has a severe effect on system performance, and is costly and time consuming to replace. 
Efficlency - The following power conditioner performance goals were established. Efficlency should be greater than $96 \%$ at full $10 a d$, and greater than $92 \%$ at $1 / 4$. load. Presently attainable efficiencies for HVDC systems are in excess of $98 \%$.

Cost - The cost goal for battery and fuel cell power conditioners established by DOE and EPRI for 1985 (In terms of 1975\$) is $\$ 60 / \mathrm{kW}$ for systems of the order of $10 \mathrm{MW}$ in quantities of at least $150 / \mathrm{yr}$. This goal is the FOB price from the vendor. By the year 2000, the goal reduces to $\$ 50 / \mathrm{kW}$.

Safety - Both AC and DC fuses must be coordinated. Potential problem areas must be analyzed separately such as the possibility of flash fires from oil used in capacitors and transformers.

Testing - Smaller systems can be tested at the vendor:'s factory, while larger systems can be field tested only as is the case with HVDC terminals. Factory testing is difficult because a true battery or fuel source is generally not avaflable and accurate source simulation is difficult. Furthermore, handling the large power flows involved can be a problem leading to the establishment of synthetic testing procedures. One of the purposes of the BEST and SBEED programs is to provide a test facility for both batteries and battery power conditioners.

Large system builders have found that in many cases, control circuit testing and debugging is more time consuming and costly than power pole testing. 


\section{Conclusions and Recommendations}

- Workers in the fleld should make better use of published information and reports. Better ways should be found to disseminate knowledge generated.

- Effictency, performance, and cost goals appear reasonable. Industry can only be assured that they can meet these if a market appears and units are built and sold.

- System related issues, such as avallability, mtbf, and maintanence should be addressed in greater depth.

- The DOE/EPRI battery and fuel cell programs as presently. detined appear to be reasonable. 'Ihe goals spectflèd should be persued.

- The SBEED program should proceed as defined with a heavy Involvement of both DOE and EPRI with the EPRI participation defined more precisely.

- DOE, Industry, and the utflitfes must obtaln a better appreclation for each others goals motives and objectives so that programs can be defined in a more effective manner to the benefit of a11 concerned. 
Working Group 3

POWER CONDITIONING FOR WIND AND OTHER TECHNOLOGY 
POWER CONDITIONING FOR WIND AND OTHER TECHNOLOGIES

L. C. Mris

Solar Energy Research Institute

Approximately 20 people attended the moraing session on the power conditioning for wind and other technologtes. These people ropresented a broad iross-section of industry, utilities, R\&D institutions and an independent consuiting engineer. The discussion was quite informal, informative and stimuiating. Everyone present did contribute to the discussion and gave their inputs to the session.

There were two speakers from the industry who made informal presentation to the group. The first speaker was Hans Meyer from Windworks and he discussed the line commutated inverter system for a grid connected wind energy conversinn system. There are about 145 installations already for Geminf Syrahronous Inverters and most of them are wind applications. The cost, performance and inteiconnection issues for this type of utility interface were addressed. According to him, the cost and efficiency goals for power conditioning in photovoltaics are presently achievable in mass production volume. However, it was mentioned that at present there are no power conditioning cosi and perfornance goals established for the wind energy conversion sytems although $10 \%$ of the total installed cost for the small wing energy conversion systems is corsidered to be a good goai for power conditioning equipment. It would help if Wind Systems Branch of DOE would establish some goals for power conditioning equipment for the manufarturers to go by in the wind area.

The next presentation was by Bob Barton of General Electric Company, Space Division. He talked about 2 MW MOD-I Boone, N.C. installation. This synchronous machine is connected to the distribution network and as far as the power conditioning for this large machine is concerned, the excitation contzol for the generato: and speed and 
torque control were the key items that were discussed.

Most of the large wind machines in this country are either AC induction generators or synchronous generators and as such there is no power conditioning involved in them, although in Europe there is some work being done in the area of power conditioning for large machines by going to the scheme of DC generator and inverter thus capturing some more energy at some added costs.

The discussion then went on to the question of identification of potential markets for power conditioning for wind applications and it centered on the question of grid connected wind energy conversion system vs. dispersed stand-alone applications. The point was brought out that there is no clear answer as yet to whether the grid connected Wind Energy Conversion Systems is the coming near term market or stand-alone application is the near term market and people present had different views on this subject and it was felt that the outcome of this issue based on the uncertain potential consumer preferences will have an impact on the role of power conditioning in the wind area. It was suggested that an economic analysis of both the markets should be undertaken to resolve the issue.

The question of safety and reliability was discussed briefly and there was no. consensus on whether the consumer is llable for the safety of equipment and personnel or whether the utility is responsible, although it was generally agreed that utilities more likely will not get involved in the operation and ownership of small wind energy conversion systems.

On the question of Improvements needed in the power conditioning in the wind area it was obvious that the requirements for power conditioning equipment have not yet been standardized, and at present these requirements vary from installation to 
installation and from utility to utility. What needs to be addressed in this area by $D O E$ and $R \& D$ institutions is to develop a set of standards in coordination with the utilities which would let the consumer know what the power conditioning and utility interface requirements are and it w111 also, to some extent, standardize the technical specifications to be met by power conditioning industry. It was suggested that a set of specifications could be applicable to the stand-alone applications and another set of standards could be applied to the grid-connected power conditioning equipment. I think this was one of the major outcomes of this session.

The issue that was raised several times and remained unresolved was regarding what R\&D work needs to be done now in the area of power conditioning for the wind systems and it was thought that the bigger issue to be addressed is the identification of major applications of wind energy conversion systems and once it is identified that a substantial market exists for stand-alone applications which require power conditio ing, the industry would then be willing to put money in the R\&D of power conditioning and most of the technical problems expected to be encountered are solvable by engineering although they will affect the cost of the wind energy conversion system. Rocky Flats program of installing 125 small wind machines over the U.S. will shed some light in this area.

In the area of other technologies besides wind, some of them were discussed in general, but no discussion was held in the area of power conditioning as applicable to those technologies.

In summary then, three recommendations that come out of this session were:

1. The need for identification of potential markets in the wind area requiring power conditioning. 
2. Establishment of cost/performance goals by DOE Wind Systems Branch for power conditioning in the wind area.

3. Development of a set of standards needed in the power conditioning and utility interface areas to be developed with the cooperation of utilities which would benefit both the users and the manufacturers alike.

In the end, I would like to thank all the particlpants for a meaningful interchange of valuable information. Thank you! 
WINDWORKS, INC.

POWER CONDITIONING ENGINEERING PROGRAM

HANS MEYER 
INIERCONECTION ISSLES

LOW PEEETRATION

- SAETTY

- economics

HIGH PENETRATION

- POWER QUALITY

- PONER OUTPUT PPEDICTION

- POWER HANDLING 


\section{LIE-COMUTATED SMERIER}

\section{ADVANTACES}

- LOMER SYSTEM STRICTURAL LOADS

- HIGER SYSTEM ERERGY OUITUT

- SIMPLIFIED RDTOR CONTROLS

- HIGHER RDTOR SPEEIS

- high geEERATOR efficiencies

- gOOD AVAILABILITY

\section{DISADVANTAGES}

- HIGHER POWER SYSTEM COST

- GREATER POWER SYSTEM COMPLEXITY

- LONER POWER QUALITY

- LOW PONER FACTOR - VARIABLE VARS 
ADVANTACES

- LOH POWER SYSTEI COST

- POAER SYSTEM SIMPLICITY

- HIGH POWER QLALITY

- gOOD AVAILABILITY

DISADVANTAGES

- HIGHER SYSTEM STRUCTURAL LOADS

- DECREASED EEERG OUTPUT

- LONER RDTOR SPEEDS

- LOW PONER FACTOR - CONSTANT VARS

- LON geEerator efficiency

- HIGHER POWER SYSTEM WEIGHT 
LINE INTERFACED PHOTOVOLTAIC arRAY

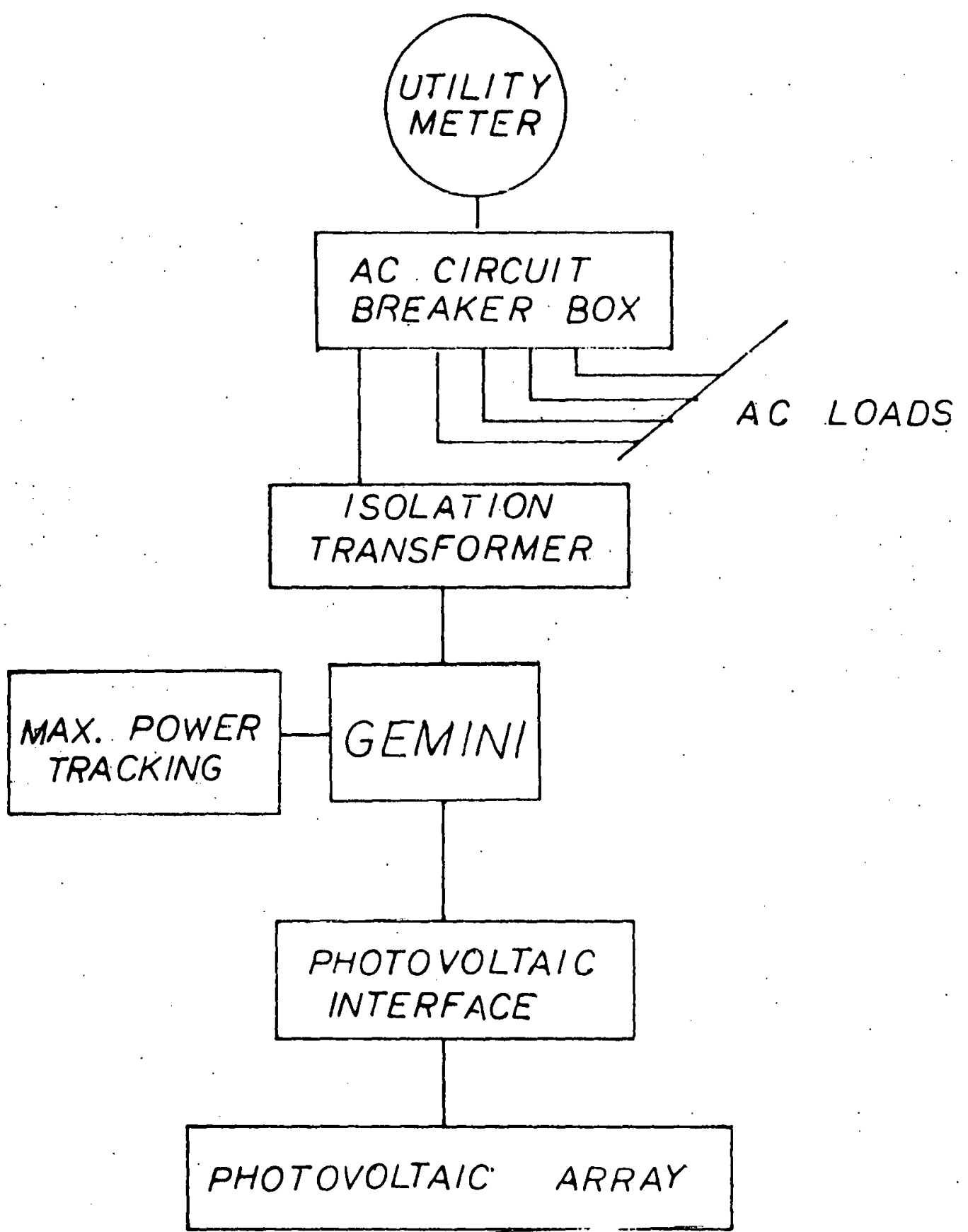




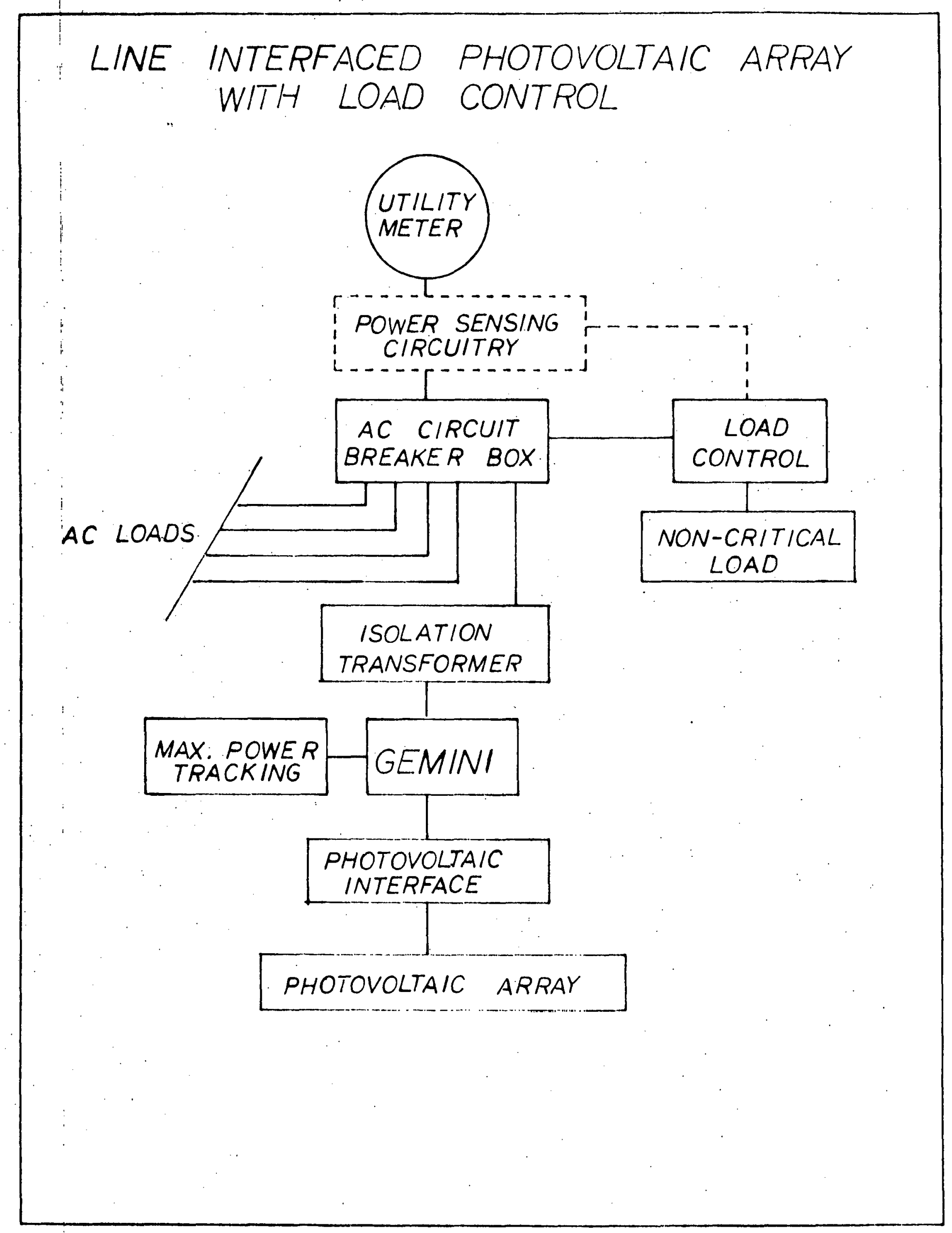


LINE INTERFACED PHOTOVOLTAIC ARRAY

WITH STORAGE

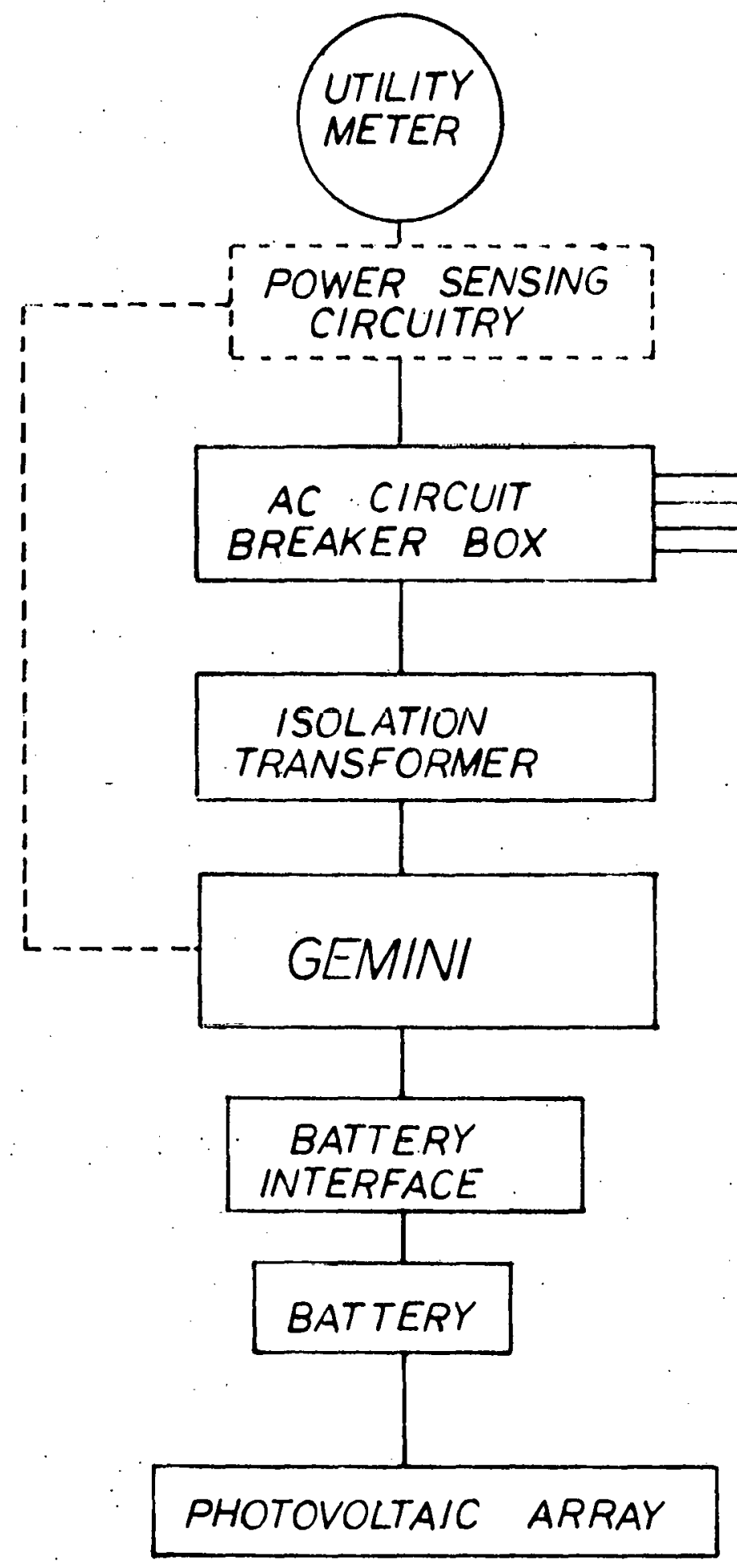




\section{PEAK SHAVING WITH LINE. INTERFACED PHOTOVOLTAIC ARRAY AND BATTERY STORAGE}

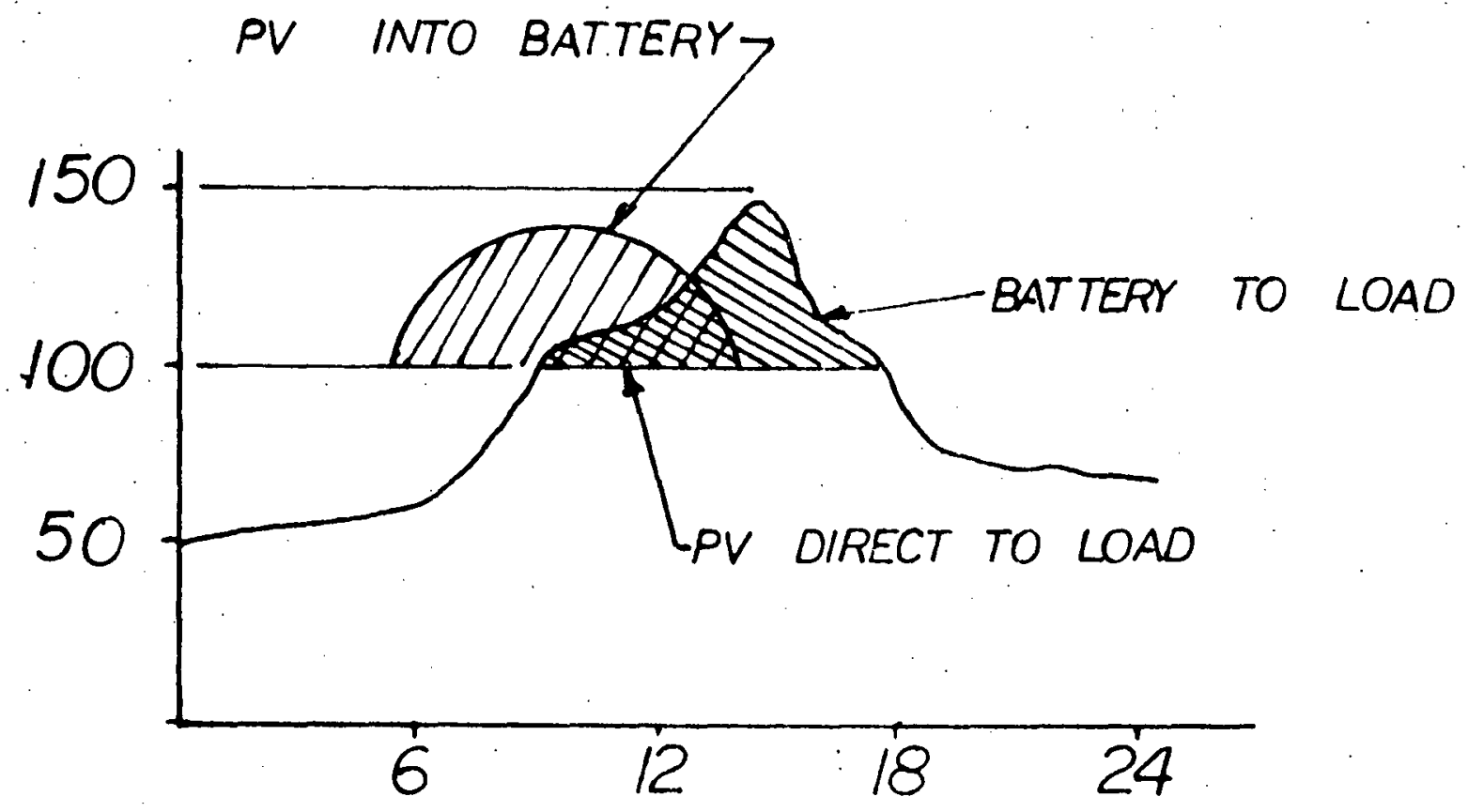




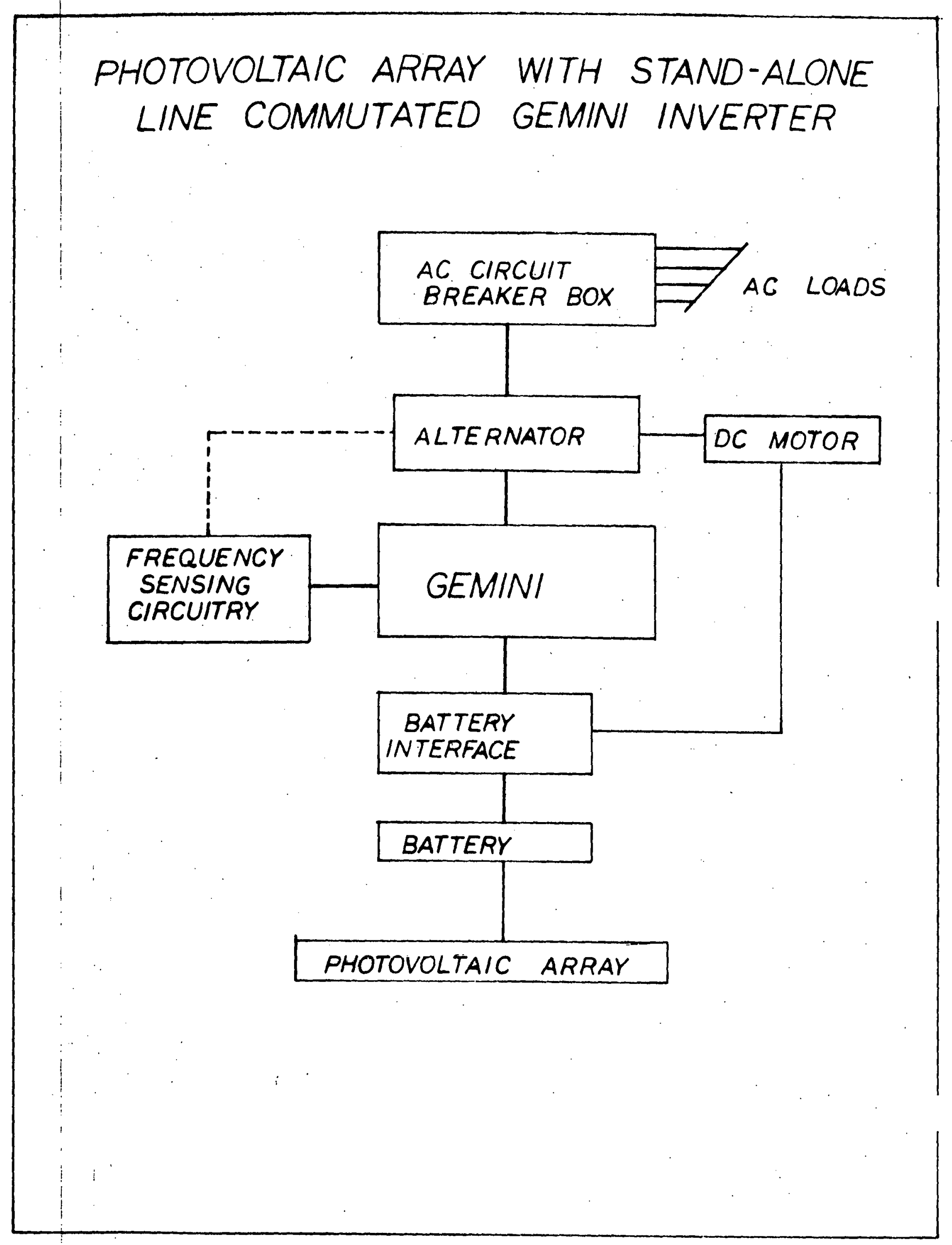




\section{GEMINI SYNCHRONOUS INVERTER EFFICIENCY VS CAPACITY}
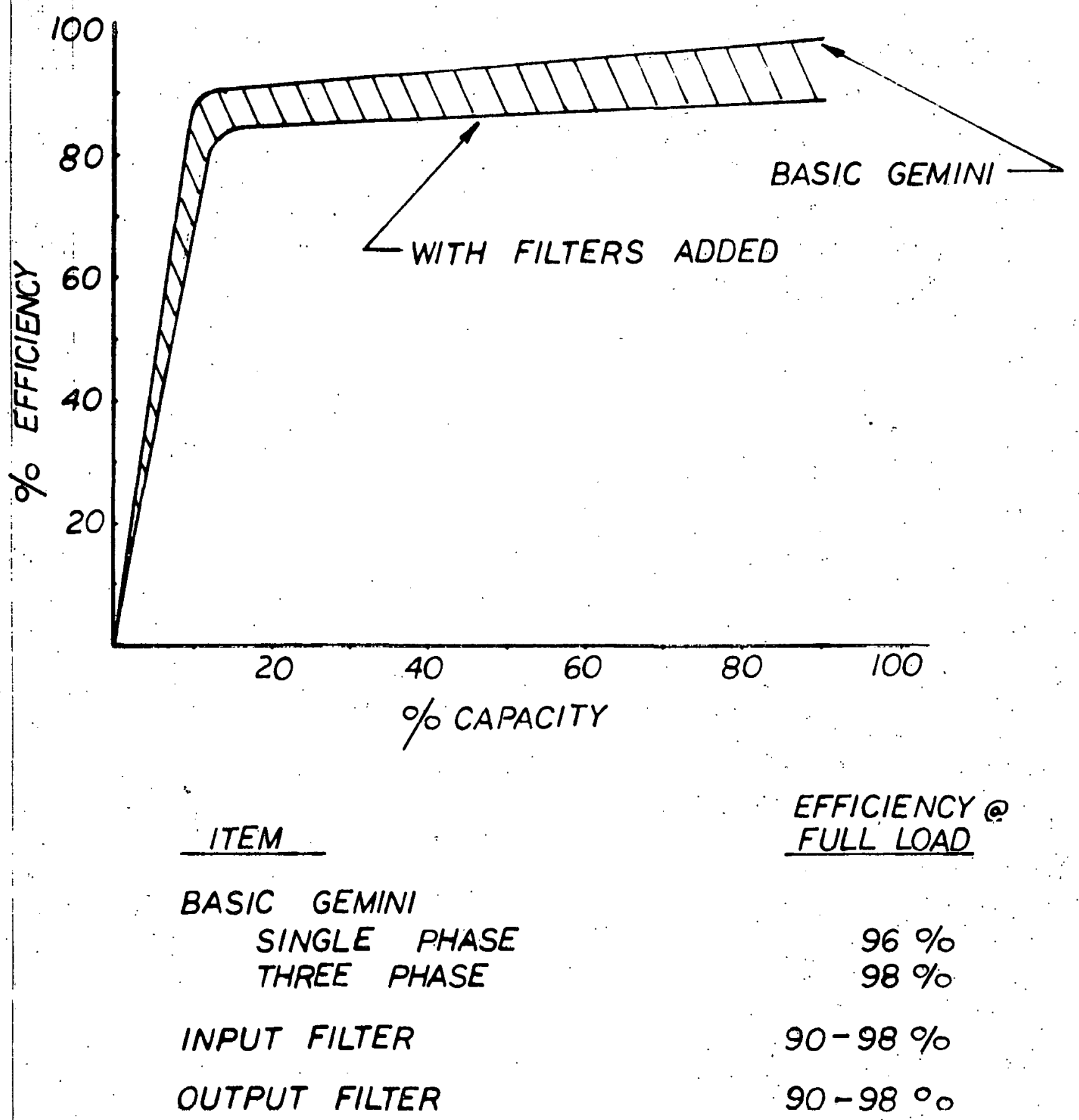

EFFICIENCY @ FULL LOAD

BASIC GEMINI

SINGLE PHASE

THREE PHASE

$96 \%$

$98 \%$

$90-98 \%$

$90-98 \%$ 


\section{GEMINI-SYACHRONOUS INVERTER COST VS CAPACITY}

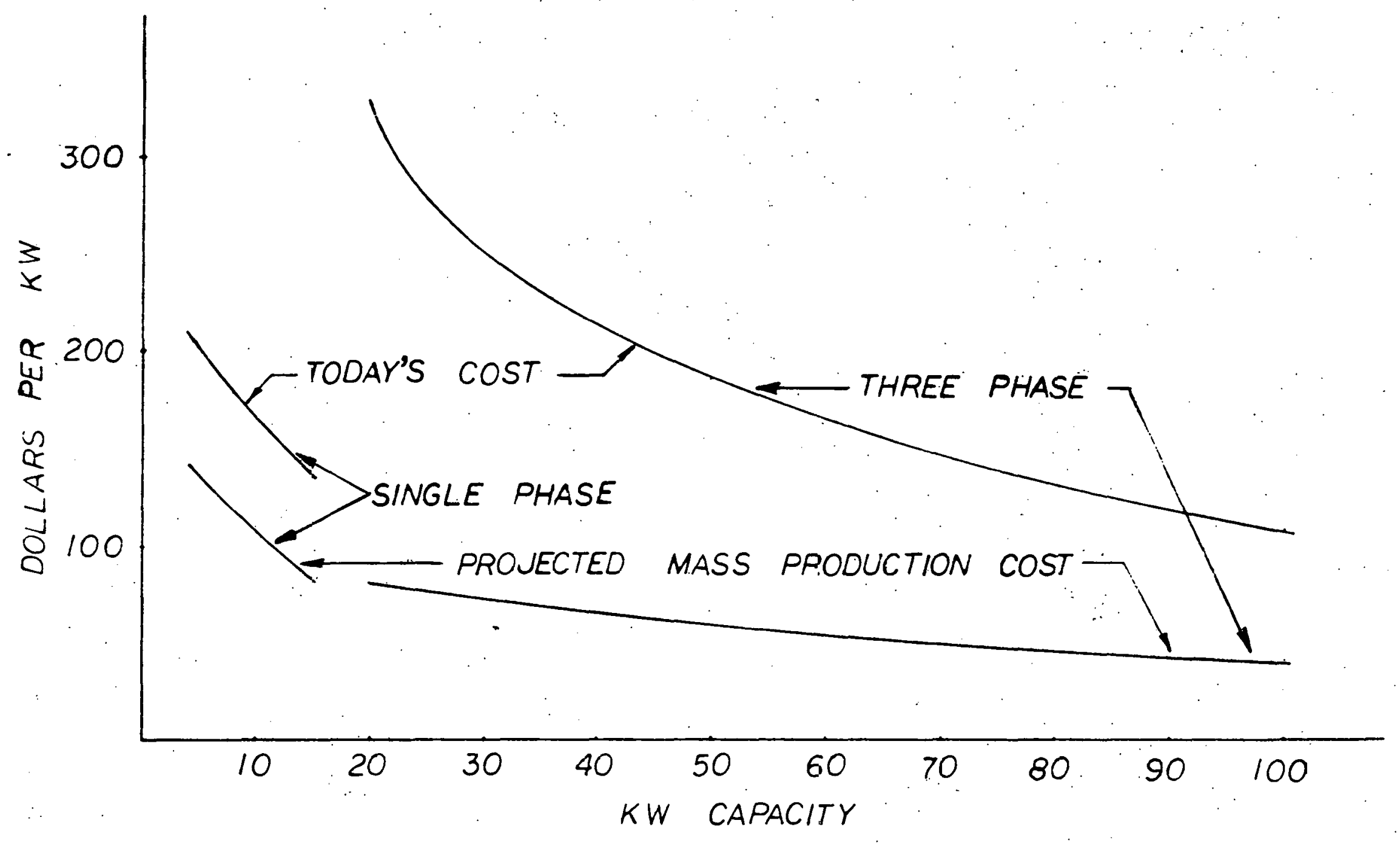




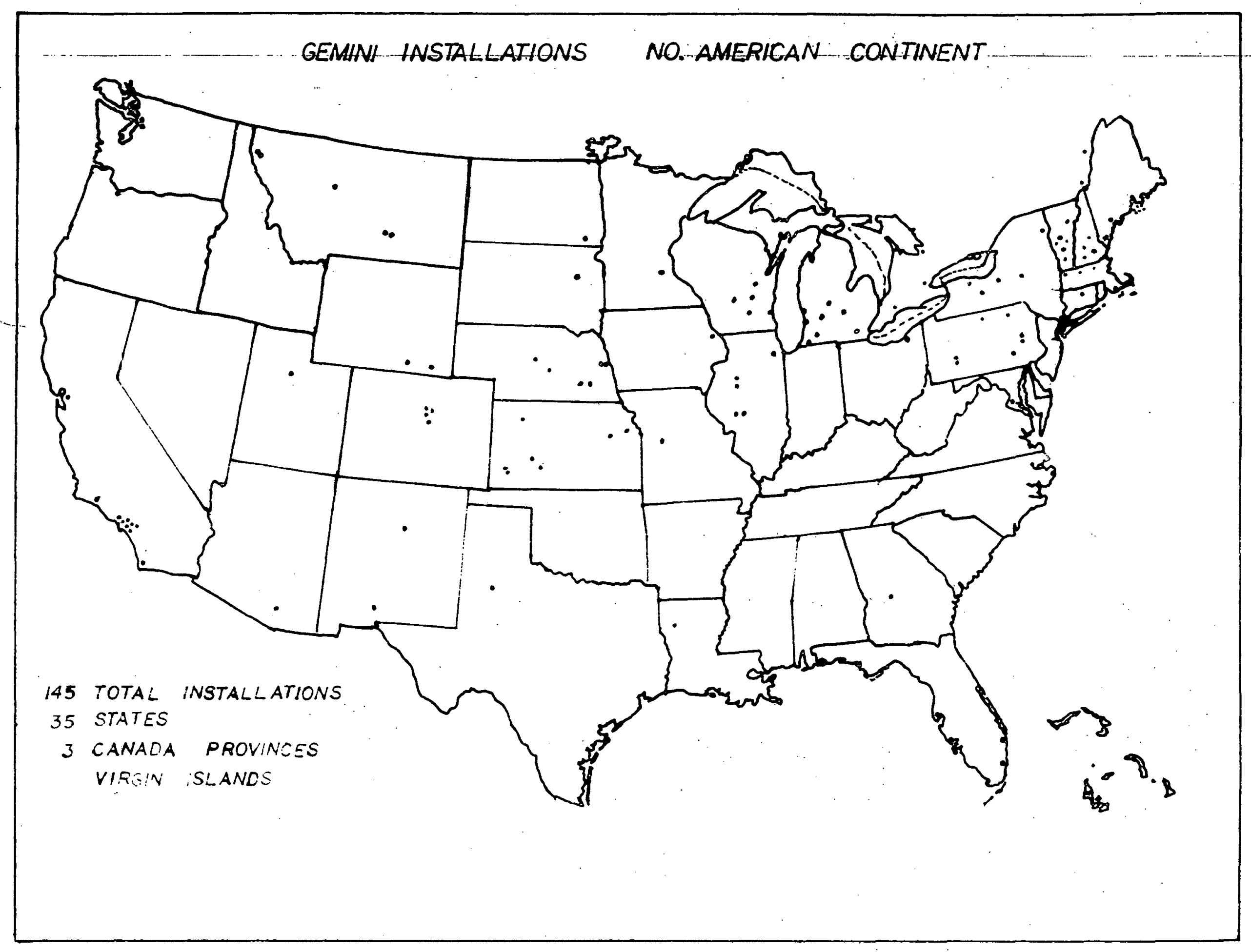


Working Group A

POWER CONDITIONING FOR LARGE SYSTEMS INTEGRATED WITHIN A UTILITY GRID 


\title{
POWER CONDITIONING FOR LARGE SYSTEMS \\ INTEGRATED WITHIN A UTILITY GRID \\ WORKSHOP SUMMARY
}

\author{
Stanley Krauthamer \\ Workshop Chairman \\ Jet Propulsion Laboratory \\ Pasadena, California
}

\section{INTRODUCTION}

This document represents a summary of the workshop on "Power Conditioning for Large Systems Integrated Within a Utility Grid" prepared by the Workshop Chairman.

With the advent of the rapid development of alternate energy and storage sources the methodology of interfacing this energy into a utility grid provides an interesting challenge. The interfacing power block between the alternate sources and the utility grid is labeled a power conditioner. The alternate energy source and the requirements for interface with the utility grid places certain design and performance constraints upon the power conditioner.

The basic issues dealing with power conditioners were broken down and discussed with respect to the following categories:

- State of Technology

- Available Technologies

- Hardware Availability

- Power Conditioner Costs

- Performance and Operational Requirements

- Requirements to Stimulate Development

- Technology Development Recommendations and Comments

The working group was made up of approximately 24 persons (the exact number varied as several persons rotated between working groups). Included in the above was a panel of six persons, all specialists from private industrial concerns. Thirteen of the group members represented private industrial concerns, three members were from utility organizations, one represented a university and three represented government agencies and national organizations.

The working group was addressed by the Chairman and the six panel members. The discussions were informal in nature and addressed the various relevant systems and power conditioner issues. 


\section{STATE OF TECHNOLOGY}

Power conditioner technology is a reasonably mature technology. Substantial experience has been gained over the past number of years. Four major areas of power conditioner technology are as follows:

1. Uninterruptible Power Supplies (UPS)

2. AC Adjustable Speed Inverter Drives

3. High Voltage DC Transmission (HVDC)

4. VAR Generators

UPS systems have been produced on a rather extensive scale in the sizes of 15-600 kW. Systems have been built as large as 2.5 MWe with one unit rated at $8 \mathrm{MWe}$, in process for the Social Security Administration. These systems are generally 3ø types operating at a DC bus voltage of 120 VDC - 600 VDC. Voltage regulation is $\pm 1 \%$ and harmonic distortion is $5 \%$. Typical mechanical dimensions for a $600 \mathrm{~kW}$ UPS is $7^{\prime} \times 16^{\prime} \times 3^{\prime}$. The inverters are forced commutated types using either six or 12 pulse inverters. The basic problems of parallel operation have been mastered indicating that the typical UPS system has the potential of being connected to the utility bus with provisions for proper logic control.

There are 1000 UPS installations in the U.S. Ten systems are rated at 2.5 MWe. The UPS systems are manufactured on a volume basis and the market for these systems is quite competitive. UPS pricing can be used to arrive at base line costs for large power conditioners for alternate energy sources.' UPS units have proved to be highly reliable. On a production run of 90 UPS units for the FAA an MTBF of 17,000 hours was established (Garrett AiResearch).

$\mathrm{AC}$ adjustable speed inverter drives have been used for $\mathrm{AC}$ motor speed control for the past 20 years. Thousands of these systems, $10 \mathrm{~kW}-25 \mathrm{MWe}$, have been in operation. These systems have been used by textile fiber manufacturers, machine tool manufacturers and the railroad industry. The systems generally operate over a speed range of $6: 1$ and voltage regulation of approximately $\pm 2 \%$. The AC motors operate from low frequencies up through $400 \mathrm{~Hz}$. The systems are generally forced commutated types with either 6 or 12 pulse operation. DC bus voltages range from 100 VDC - 1500 VDC.

High voltage DC transmission (HVDC) systems are used to transmit power over great distances. Generally these systems operate at voltages above $100 \mathrm{kV}$ and powers in excess of $100 \mathrm{MWe}$. Systems have been in operation in Europe and the U.S. with excellent reliability records. A typical system at Eel River $(280 \mathrm{kV})$ shows a $99 \%$ availability and a $96 \%$ availability for two units including planned outages. A system with $6000 \mathrm{SCR}$ 's $(50 \mathrm{~mm})$ had a failure rate of three devices in two years. Redundancy of SCR's in these systens is approximately $15 \%$. The typical systems installed in the U.S. consist of 2-6 pulse line commutated bridges. One bridge in a wye-wye configuration 
and one bridge in a wye-delta configuration. This connection offers reduced harmonic distortion. For systems at $100 \mathrm{MWe}$ or below series tuned filters are used to filter the 11th and 13th and higher harmonics.

VAR generators have been developed for use in cleaning up the effects of arc furnaces on the utility. line. The VAR generators are line commutated phase controlled inverter switches. They are used as harmonic filters, power factor correction and a means to balance a 30 line. Total VAR generation capacity is 1200 MVAR. VAR machines are competitive with synchronous condensers and capacitor power factor correction. The VAR generator is basically a controlled inductor in parallel with capacitors usually termed a "Dynamic Steinmetz Balancer".

In recent years substantial efforts have been expended to develop advanced systems for large power conditioners. The three most notable systems are:

1. BEST Facility: A joint effort of DOE, EPRI and PSE\&G. This facility is designed to test out advanced electrochemical storage systems for load leveling. This facility is currently being built and should be on line in the 1980 time frame.

Facility operating DC bus will be rated at 500 VDC - 1000 VDC with peak rating at $1000 \mathrm{VDC}$ and 5000 amperes. The system will be under microcomputer control. Inversion technology relevant to this facility has been demonstrated by 1000 hours of operation of an inverter feeding into a utility grid (built by UTC).

2. Consolidated Electric of New York: This system is a joint EPRI, DOE and Consolidated Electric effort. The system is a load leveling system with a fuel cell and inverter supplied by United Technologies Corp. The system rating is $4.6 \mathrm{MWe}$ with a DC bus voltage rated from 2700 VDC to 3600 VDC.

3. SBED: This system is a joint EPRI and DOE program. The program objective is to field and test over a period of nine years a load leveling system rated at 10-20 MWe with electrochemical storage of from 3-5 hours. This system is currently out for competitive bid.

AVAILABLE TECHNOLOGIES

Two technologies are currently used for large power conditioners connected to a utility grid. These technologies are the forced commutated types and the line commutated types. The forced commutated types use external methods to turn off the power SCR devices whereas the line commutated inverters use the utility grid to turn off the power SCR's. There are many advantages and disadvantages for each technology. The characteristics of these systems are available from the various power conditioner manufacturers. Once a number of systems of both technologies are integrated into a utility grid, then a proper 
assessment of each system can be made. The market place will be the final determinant as to which technology is technically and cost-wise the most adequate.

\section{HARDWARE AVAILABILITY}

Various types of hardware are available either as an off-the-shelf or as a developmental type unit that will interface with a utility grid. Power ratings range from $40 \mathrm{~kW}$ to $14 \mathrm{MWe}$. The optimum systems from a cost point of view are available at 14 MWe from UTC and 12 MWe from Garrett AiResearch. Other vendors will likely have similar ratings. DC bus voltages will range from 2200 VDC to 3800 VDC for optimum costs. It is anticipated that most systems will have microprocessor control for operation purposes and power management purposes.

\section{POWER CONDITIONING COST}

Power conditioning costs vary as to technology types, MWe size and available DC bus voltages. Several of these issues are addressed in EPRI Reports RP841-1, 842 , 255. Cost projections for advanced $3 \emptyset$ UPS systems are as follows (DC input-AC output):

\begin{tabular}{|l|c|}
\hline KVA & $\begin{array}{c}\text { Selling* } \\
\text { Prlce } \$ / \mathrm{kW}\end{array}$ \\
\hline 10 & 500 \\
\hline $1 \mathrm{MVA}$ & 200 \\
\hline $10 \mathrm{MVA}$ & 100 \\
\hline $15 \mathrm{MVA}$ & 85 \\
\hline
\end{tabular}

*1985 time frame (1979 dollars) (Exide Power Systems)

For $\mathrm{DC}$ input-AC output systems a cost of $\$ 150 / \mathrm{kW}$ for $8 \mathrm{MWe}$ size reflects current prices.

For the advanced technology inverters $14 \mathrm{MWe}, 2200 \mathrm{VDC}$ - $3600 \mathrm{VDC}$ inverter costs are $\$ 45 / \mathrm{kW}$ at a production rate of 150 units/year (1975 dollars). The cost of the advanced technology inverters can cost from five to 10 times the $\$ 45$ when quantities are quite small. It should be noted that inverters below the 14 MWe rating will show increased costs as MWe ratings are reduced (UTC).

HVDC systems are reviewed in EPRI Report RP390 with anticipated costs being $\$ 30 / \mathrm{kW}$. Current market costs reflect about $\$ 100 / \mathrm{kW}$ (GE) .

PERFORMANCE AND OPERATIONAL REQUIREMENTS

A detailed performance and enviommental specification is necessary in order to adequately interface with the generation or storage source and the utility 
grid. Generation sources will vary in voltage level. In addition the voltage range of operation will vary according to the generation source and the type of electrical storage if any. Advanced electrochemical storage systems should be clearly defined since a particular charge or discharge cycle may be excessive with respect to the capability of the power conditioner. Generally the power conditioners that have been described are adequately flexible in design so that they can be applied to an extensive range of applications. These applications extend from photovoltaic systems, solar thermal systems, MHD systems, wind systems and load leveling systems.

Efficiency requirements are high in order to have low delivered energy costs. The UPS systems described previously typically have an inverter efficiency of 95\% ( 600 VDC bus). The advanced technology inverters typically have efficiencies of $96 \%$ at full load and $92 \%$ at $25 \%$ 10ad (14 MWe, 2200 VDC - 3800. VDC).

Utility line interface is another area which must be more clearly defined. These efforts for a more clearly specified direction will require the joint involvement of DOE, EPRI, Electric Utilities and Power Conditioner manufacturers. Some of the issues of line interference are addressed in EPRI Report 1024-1. Generally a 5\% distortion of voltage or current is acceptable, but as a greater number of dispersed generation and storage units are interfaced with the utility grid, this value will likely be reduced toward 1\% total harmonic distortion. Requirements at the Best Facility are $2 \%$ maximum harmonic injection.

Performance testing is an area of great importance since it is desirable to system or module test of the power conditioner prior to installation. Various methods for testing were discussed. These varied from calculation of losses for efficiency determinations to circulating module power back to back to supply only the module losses. Microprocessor control can aid in system testing and system trouble shooting. The microprocessor can be utilized as an important diagnostic tool.

REQUIREMENTS TO STIMULATE DEVELOPMENT

During the past several years important technical strides have been made in the development of advanced technology power conditioners. Two areas of support are suggested in order to arrive at optimum cost, efficiency and reliability goals. These areas are:

1. Additional development contracts to improve technology and componentry (see program recommendation and comments).

2. Placement of production contracts for large power conditioners to assist in optimizing cost, efficiency, reliability goals and delivered energy cost goals. 
TECHNOLOGY DEVELOPMENT RECOMMENDATIONS AND COMMENTS

During the workshop session various suggestions were made relating to both component and system technology and program direction. These suggestions have been summarized and are detailed as follows:

1. Develop system modeling of delivered energy cost versus component cost.

2. Provide better interface with various component vendors (battery, inverter) contractors and utilities to improve more adequate system engineering.

3. Analyze slew rate of batteries and other energy sources.

4. Review new technology batteries and power sources for unusual interface requirements.

5. Utilities to provide guidance for identification of permissible harmonic levels and utility characterization.

6. For forced commutation inverters the following technology areas would improve system cost, efficiency and protection.
A. Operation of inverter with a faulted bridge with hïgher härmonics.
B. Improved commutation capacitor technology.
C. Improved DC fusing technology.
D. Development of inverters with higher switching frequency for improved harmonic cancellation.
E. Advanced packaging and cooling methods.
F. Application of microprocessor technology to inverter and system control.
G. Improved power conditioner efficiency.
H. Snubber circuit technology improvement.
I. Improved SCR voltage, current and turnoff characteristics.
7. Allow market place to identify the most viable technology (line com- mutation versus forced commutation) from the standpoint of inverter cost, delivered energy cost, performance criteria. 
8. For line commutated inverters the following should be investigated for improved cost, efficiency and ripple reduction and system protection.

A. Three inverter bank versus two bank systems for reduced harmonics.

B. Filter optimization for reduced harmonics.

C. Larger $\cdot$ SCR's $^{\prime}(100 \mathrm{~mm}$ cells).

D. Application of liquid cooling.

E. Improvements in capacitors and use of synchronous capacitors.

F. Continued development of static DC intermutor with add-on microprocessor control.

9. Larger number of phases in line commutation inverter do not necessarily improve harmonic performance; therefore, development efforts may not provide performance improvements.

10. Review static interrupter performance versus mechanical interrupter in terms of cost, protection and systenl performance.

11. System electronic controls should be diagnostic in nature and remotely controllable for utility system power management.

12. Factory testing of power conditioners should closely simulate the real installation environment. Procedures and methodology should be investigated.

13. Study efforts should be extended in characterizing of system performance. A generalized system specification should be developed including electrical performance, environmental requirements, reliability, etc.

14. Analysis of power conditioner modularity as related to cost reduction of installation costs.

15. Analytical models are necessary for sources (PV, MHD, fuel cell, battery, etc.).

16. More inverter units needed to be built to identify.cost, reliability and performance issues. 


\section{CONCLUSION}

The overall conclusion of this workshop was that a great deal needs to be done in the areas of power conditioner technology development, performance specifications and standards, harmonic injection and modeling of utility systems in order to more adequately predict operational performance. It is also recommended that additional funding be supplied to initiate power conditioner production in order to identify the system interactive problems and sensible cost goals. Production expertise is necessary to provide a viable system and product. 


\section{MEMBERS OF THE POWER CONDITIONING FOR LARGE SYSTEMS INTEGRATED WITHIN A UTILITY GRID WORKSHOP GROUP}

The Power Conditioning for Large Systems Within a Utility Grid Group consisted of the following persons reflecting a cross-section of industry, universities and government experience.
R. Anderson
Standard Oil of Calif.
D. Englebrecht
R. Ferraro (Panel Speaker)
Texas Power \& Light
R. F1ing
E. Fuchs
K. Harner
S. Krauthamer (Panel Chairman)
EPRI
B. Lindquist
Aerospace Corp.
A. Maltz
W. Miller
R. Pohl (Panel Speaker)
University of Colorado
Hamilton Standard
JPL
Chevron Research
PSEĘG
J. Prohaska
T. Prouty (Panel Speaker)
Martin Marietta Aerospace Corp.
F. Robinson General Electric Co.
D. Roesler
G. Schmidt
J. Vivirito (Panel Speaker)
J. Walter
A. Wellford (Panel Speaker) Alcoa
P. Wood (Panel Speaker)

Garrett AiResearch
Garrett AiResearch
DOE, EES
AEG - Telefunken
UTC Power Systems Division
Sandia Laboratories
Exide Power
Westinghouse


Working Group B

POWER CONDITIONING FOR SMALL DISPERSED SYSTEMS INTEGRATED WITHIN A UTILITY GRID 
POWER CONDITIONING FOR SMALL, DISPERSED

SYSTEMS INTEGRATED WITHIN A UTILITY GRID

WORKING GROUP REPORT

DANIEL S YORKSIE, GROUP LEADER

WESTINGHOUSE AEROSPACE ELECTRICAL DIVISION 


\section{INTRODUCTION}

Large numbers of small photovoltalc PV sysiems in residential and intermediate-size applicatlons present new and significant challenges to both the power conditloning system designers and the local operating utillty. These challenges can be addressed in an orderly and timely manner and, If so addressed, will facllitate the commerclalization of photovoltalc systems.

The purpose of this working group was defined to Include the following:

* Assess current and future technology.

* Identify operational requirements.

* Identify mass production and marketing requirements.

* Identify means to stimulate development.

The scope of the working group included power conditioning systems ranging in stze from ifive to flve hundred KVA. This range includes farm, residential, light manufacturing, and commerclal applications (1.e. shopping centers, condominlums, etc:). The interface to the utility for these various applications is well defined by existing utility distribution network design and is shown in Figure l. A more detalled statement of scope was presented (see Figure 2) and accepted by the working group.

The working group was presented with a list of potentlal topics for discussion (see Figure 3) and a suggested priority for these topics (see Figure 4). It was agreed to discuss these toplcs in the order of priorIty suggested but due to time constraints effort would be concentrated on topics one, two and three. In an attempt to stimulate discussion and provide inputs for working group consideration limited background inforination on interconnect policles, warranties and regulatory policies was presented. This information is contained in Appendix I to this working group report.

The working group then proceeded to address these topics and to formulate a set of recommendations. Overall group effectiveness was enhanced by the diversity of viewpoints presented including government, private laboratories, utilities, universities and industry. A detalled listing of participants is included in Figure 5.

The following sections present a summary of working group discusslons on each of the three groups of toplcs followed by a summary of overall recommendations and conclusions. 


\section{GROUP I TOPICS - POWER QUALTTY:}

Power Quality includes power factor presented to the utility, current and voltage harmonlcs and radiated or conducted EMI。 Historically utilities have relied on Telephone Interference Factor (TIF) rating to control the quality of power generated by rotating apparatus. These requirements are spelled out in ANSI C50.13 - 1977. Recognizing the needs for more specific guidelines for solld state apparatus the Static Power Converter Committee of the Industry Applications Society of the IEEE has published a preliminary guide for certaln types of equlpment entitled "IEEE Gulde For Harmonic Control And Reactive Compensation of Static Power Converters". Some utllitles are becoming increasingly concerned about the effect on power quality of varlous types of connected apparatus. Large numbers of photovoltaic systems could have a deletereous effect on power quality if guldelines for the power conditioner designers are not established in a timely manner. Typically today some utilities have limits on power factor in the range of 0.9 lead/lag. Standards have not been set for current or voltage harmonics but typical values of $10 \%$ for current and $5 \%$ for voltage are being considered. Obvlously with few such systems very loose requirements can be tolerated but as the numbers of such systems increases tighter limits wlll be imposed. The working group agreed that PV systems should not be made to meet more severe requirements than what is being imposed on other apparatus. Large numbers of small dispersed systems may also create other problems Including:

* Distribution network resonances.

* Distribution network stability.

* TV Interferences.

* $\mathrm{AM} / \mathrm{FM}$ radio interference.

* Radlated EMI.

It was polnted out that NASA Lewis Research Center has obtalned limited data from a single $8 \mathrm{KW}$ PV installation Including a line commutated inverter. Although no TV or FM radio interferences was detected, buzzing in the AM radio band was encountered. Another area of concern was the possible effect of poor power quality on digital (computer) installations although no specific examples were cited. The working group generally agreed that the problem will get worse in time if not addressed. Performance criterea needs to be established to gulde manufacturers of power conditioning equipment and also DOE in sponsoring development work in this area. 
Credit for power flow into the utility in PV sites without energy storage can be a significant factor in overall site economics. Only a few utilities are presently addressing this situation and no firm policies and rate structures have been established. In small PV installations with energy storage (1.e. batterles) this factor will probably not be significant. The consensus of the working group was that the two parallel non-reversing watt-hour meter arrangement will become standard. Since the cost of electricity basically includes both a demand charge and an energy charge a possible reasonable and equitable rate structure would consist of the utllity selling power at a composite rate reflecting both demand and energy charges and crediting the customer at the energy charge only for power fed back to the utillty.

Concern was expressed about potential problems due to significant changes or alternation of the traditional demand profile when large penetration of PV systems occurs. This will probably require more sophisticated control schemes by the utility but no unmanagable problems are anticipated.

\section{SAFETY:}

The question of safety was explored from several different perspectives. After the initial discussions it became apparent that the question of safety is more complex than it first might appear. Electric utility linemen, even when following operating procedures, may be working on higher voltage lines (1.e. $13.8 \mathrm{KV}$ ) which are not absolutely grounded. With several PCU's, Irrespective of type (1.e. line or self-commutated), are operational on the low voltage side the potential exists to back feed the H.V. line thus creating a safety hazard. Rellable and positive means must be designed into the PCU to prevent this equipment from energizing a "DEAD" utility line. A posslble scheme might include the utillty providing a power line carrier signal which all PV power conditioners would monitor. Absence of this signal would result in all PCU's disconnecting from the utility. Safety of the homeowner must also be considered in the design of power conditioning equipment and sufficient protective equipment must be included in the design to eliminate hazardous operation. Certain system configurations may pose special hazards. For instance, with battery installations a dead short within the PCU could result in dangerous conditions. It was agreed that the PCU must be designed to protect itself internally and not to create a hazard at its interfaces. However, other system requirements such as explosive atmosphere are the responglbility of the approprlate subsystem. 
NOTE: Several EPRI studies Including RP1192 should provide additional information or power quality and network implications.

\section{GROUP 2 TOPICS - OWNERSHIP}

Several forms of ownership are posstble Including private, leasing and utllity. Utllity representatives expressed the vlewpoint that the majority of electric utilities would not be interested in ownership of small residential units especially in view of the fact that such systems would include rooftop arrays permanently attached to the dwelling. However, medium-size installations such as shopping centers or industrial park complexes of a few hundred kllowatts or larger may be of interest to utilities from an ownership consideration. A possible approach for small residential units would be leasing from the utility, however costof-money considerations may not favor this approach.

It was generally concluded that residential units will be bullt into the home by the contractor, posslbly with some form of government support or subsidy, and be financed via the typlcal home mortgage route. Government incentives and support will definitely be required before large numbers of residential applications become a reallty.

The working group was also made aware of current legislative action In some states directed at prohlbiting electric utllities, oll companies, etc., from becoming significant factors in this new energy market. This further supported the working group conclusion regarding private ownership.

\section{WARRANT IES:}

The power conditioning unit is probably the most reliable element in a PV installation. Experience from other applications such as uninterruptable power supplies indicates 17,000 hour MTBF's are achlevable for residential size units. Based on operating hours this represents 5 to 7 years for PV systems. Current design life of 10 to 20 years is acceptable.

The working group concluded that a one-year warranty appears reasonable and fair.

\section{SERVICE:}

After a general audience discussion of this toplc the group concluded that the "IDEAL" form of service will be the small local business trained to service the products from a number of manufacturers simllar to the local TV/Radio repalr service today. 


\section{GROUP 3 TOPICS - ECONOMICS AND STANDARDS}

Standards definitly affect product cost. This is true of both product quality standards and product performance standards (1.e. waveform quality). It was pointed out that electric utllitles should logically take the lead in setting guidelines and standards but that DOE has a responsibility to insure that reasonable guidellnes and standards are formulated to gulde manufacturers of power conditioning equipment. These standards should be no more stringent than for other equlpment and may in fact evolve from less to more strict as market penetration of PV systems Increases.

On the question of economlcs the working group agreed that present goals are reasonable and achlevable. However, current power conditionIng development programs are based on refining and applying the technology gained from UPS, military P.S. and Industrial solld state drives. The PV marketplace represents orders of magnitude larger quantities and hence opens the door to advanced and innovative design approaches. VLSI technology and custom hybrid power modules coupled with high frequency conversion techniques to minimize the dollar value of mature components (1.e. inductors, capacitors, transformers) should be investlgated to determine if such designs will yleld further signiflcant cost reductions. Total system cost must be minimized and any subsystem capable of offering further cost reductions must be vigorously pursued.

\section{RECOMMENDATIONS AND CONCLUSIONS}

The following list of recommendations and conclusions were arrived at by this working group.

* Power quality will become of increasing concern to utilities as PV systems increase their market penetration.

* Electric utllities are just starting to address the problem and there may be variation from location to location.

* Typical utility interface requirements may include the following limits :

0.9 power factor, lead or lag. (watts/volt amperes)

Voltage total harmonlc distortion of $5 \%$

Current total harmonlc distortion of $10 \%$ 
* Dual power meters will probably become standard with utllities selling at a composite demand/energy rate and crediting at the energy rate only.

* DOE should sponsor a study to determine the impact of multiple dispersed PV systems on the electric utility grid.

* DOE should use existing and planned PV demonstration sites to take measurements and study the effects of conducted and radiated EMI/RFI generated at both the AC Interface (ut1lity) and the DC interface (array). Effects on TV, radio and computers should be determined and guldelines established.

* Theoretical analyses of the Impact of large numbers of dispersed PV systems should be confirmed by appropriately sized fleld trials. For example, DOE subsidizing the installation of a number of residential PV systems in a typlcal subdivision or mllitary base would provide such a test bed.

* A limited number of high risk advanced technology power conditionIng development programs should be funded by DOE in support of the overall PV goal to minimize total system cost. 


\section{IIST OF PARTICIPANTS}

POWER CONDITIONING FOR SMALI, DISPERSED

SYSTEMS INTEGRATED WTTHIN A UTIITY GRID

Paul F. Pittman

J. W. Yerkes

Roy H. Richardson

R. Zacharski

George Minges

Hal Nelson

Louis Schaffer

Stephen Kugle

Michael Fuchs

Bruce Blevins

Vladimir Brunstein

Ken Parkany

Bob Barton

Kay Firor

Roger Bell

Roger Peterson

Sherbourne Prescott

\section{Westinghouse}

Arco Solar, Inc.

National Park Service

Rockwell International

Rockwell International

Rockwell International Wind System

AAI Corporation

University cf Texas at Arlington

Chevron Research Company

New Mexicc Solar Energy Institute

Nova Electric, Nutley, N.J.

UTC - Power Systems Division

General Electric

SERI

Martin Marietta

Honeywell

JPL 
IIST OF PARTICIPANTS, CON'T.

Frank Goodman

Jay Tathrop

N. D. Salamandar

Ta-Lsien Wei

Bill Raddi

R. R. Ferber
Los Angeles Dept. of Water \& Power

Clenicon University

Tennessee Valley Authority

North Carolina A \& T State Univ.

ESB Technology

Jet Propulsion Lab 


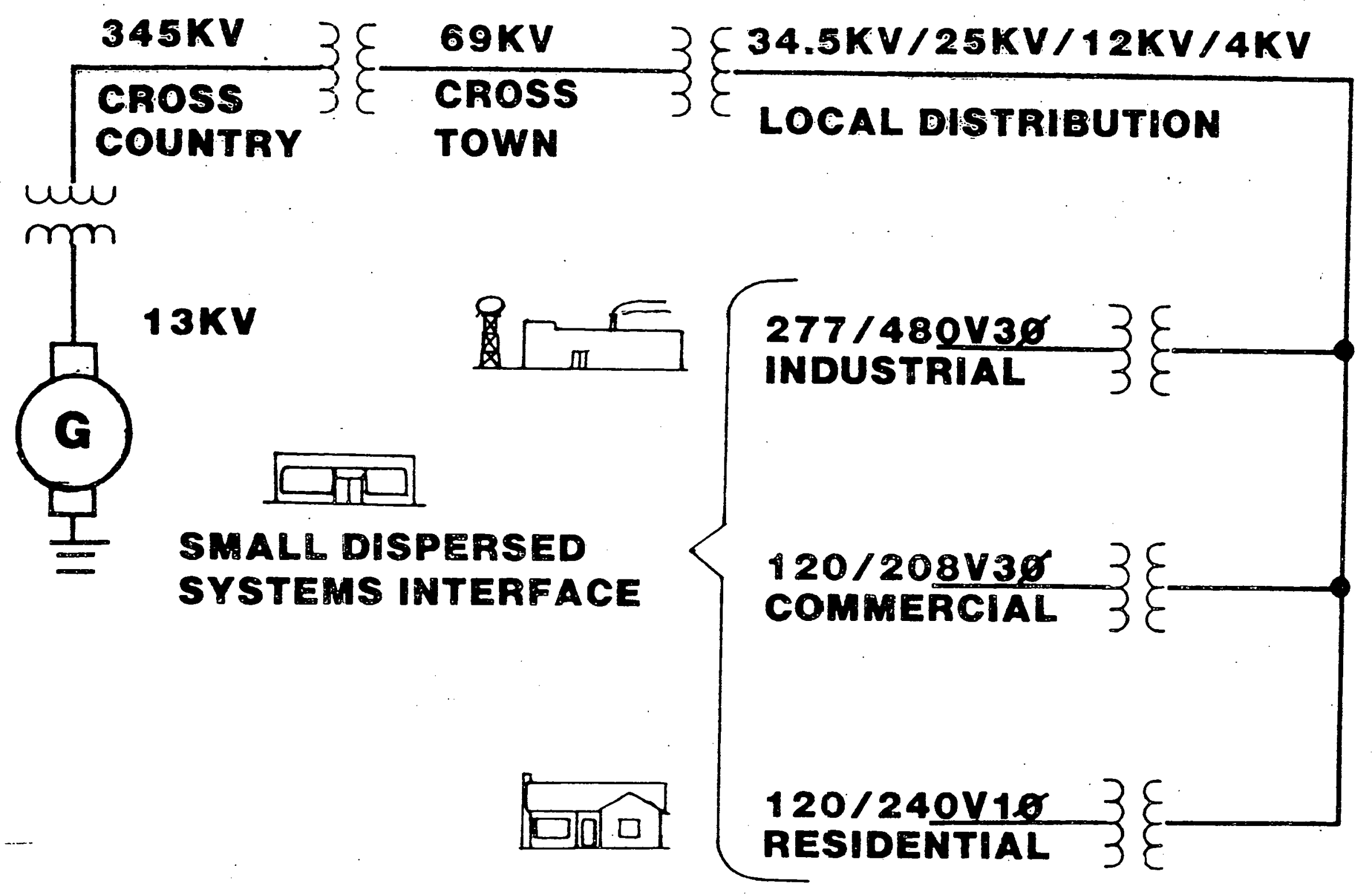

TYPICAL UTILITY DISTRIBUTION

Figu $\geq 1$ 


\section{STATEMENT OF SCOPE}

- POWER CONDITIONING

Electronic apparatus for converting DC Output of PV Array to utility grade AC. power.

- POWER leVEL

Typically 5-20KVA 50/60 Hz Single

Phase or 20-50KVA Three Phase.

Multiple unit clusters less than few hundred KVA.

- DISPERSED

Few hundred feet between units to a few miles between units.

- UTILITY INTEGRATION

Must be capable of operating tied to a utility line. May also be capable of operating without the utility.

Figure 2 


\section{STATEMENT OF SCOPE (continued)}

- TYPE OF USER

Residential, small manufacturing, farm.

- TYPE OF LOADS

Utility type including motors, pumps and machinery.

- CONFIGURATIONS

Attended/Unattended automatic with/without energy (battery) storage.

- LOCATION

Worldwide developed and developing countries. 
- Power Level

- Reliability/Maintainability

- Warranty

- Service

- Power Quality

- Safety

- Electromagnetic Interference, Compatibility

- Economics

- Instrumentation/Gauges

- Pover Flow Into Utility

- Reversal of Watt-Hour Meters

- Ownership-Leasing, Private, Utility

- Harmonics-Voltage, Current

- Acoustic Noise

- Testing

- Design Life

- Environment-Temperature, Humidity

- Peak Power Tracking

- Packaging-Physical Size,

Volume, Dimension Constraints 


\section{SUGGESTED PRIORITY FOR}

WORKSHOP TOPICS

\section{PRIORITY 1}

- power quality

- Power Factor To Utility

- Current Harmonics

- Voltage Harmonics

- SAFETY

- POWER FLOW INTO THE UTIRITY

- M Meter Reversal

\section{PRORITY 2}

- RELIABILITY IAVAILABILITY

- MAIIVTAMABILITY

- warrantiv (DESIGN LIFE)

- SERVICE

- OWNERSHIP

- Consumer Credit Terms (Private)

- Lease

- Utility Ownership 
SUGGESTED PRIORITY FOR

WORKSHOP TOPICS (Continued)

PRIORITY 3

- ECONOMICS

- STANDARDS

- PEAK pOWER tRACKING

PRIORITY 4

- ENVIRONMENT

- PACKAGING 


\section{APPENDIX I}

\section{BACKGROUND INFORMATION}

- INTERCONNECT POLICIES

- WARRANTIES

- Regulatory acts 
GEORG POWER COMPANY Statement of Requirements For Parallel Operation Of Customer Generation

1. Prompt removal of infeed whenever a fault occurs. Ownership of protective devices preferably is with G.P.C.

2. All generators greater than $10 \mathrm{KVA}$ must be thiree phase.

3. Additional interconnect equipment cost to be borne by customer.

4. Negative sequence currents may flow in the customer's generator and he must protect for them. 


\section{GEORGIA POWER COMPANY Statement Of Requirements For Parallel Operation of Customer Generation (Continued)}

5. Normally power transformer isolation is required.

6. Customer will not be permitíed to energize a dead G.P.C. Circuit.

7. Revenue metering will include two parallel connected non-reversing watt-hour meters.

8. Interconnection shall not cause any reduction in the guality of service being provided to other customers with no abnormal voltages, frequencies or interruptions being pernitited. 
WARANTIES

FrOm SOLAR AGE (MAY 79)

"A Challenge for Warranties"

W. L. Maworth \& J. M. Mattila

- MANDATED BY GOVERNMENT

$\because \quad$ - EVOLVE FROM MARKETING TOOLS AT THE DISCRETION OF INDUSTRY

- WARRANTY LIMITS

- Defects in material and workmanship for components drive system.

- Dismantle, shipping, re-install costs.

- Parts

- Labor

- DURATION OF WARRANTY

- TRANSFERABILITY OF WARRANTY

- HAINTENANCE CONTRACTS

- URIFORMITY \& SIMPLIFICATION 


\section{PURPA}

The Public Regulatory Police Act of 1978 requires that all state regulatory agencies conduct an extensive review of utility rate structure.

- Cost of Service

- Time of Day Rates

- Interruptible rates

- Declining Block Rates

- Load Management Techniques

State agencies are not required to adopt any changes but if they do not accept the federal standards, they must explain their reasons to the public. 
Working Group C

POWER CONDITIONING FOR STAND-ALONE AND DC APPLICATIONS 
10 May 1979

Group C

1:30-4:30 PM

\section{INTRODUCTION}

The purpose of this workshop was to assess power conditioning for use in stand-alone and DC systems. Participants included respresentatives from PV array, power conditioning and battery manufacturers; military application representatives, and private contractors (including one from the recreational field--Disneyland). There were no participants present from DOE, the cducational field or public utilities, possible because other meetings of greater interest to these groups were going on concurrently.

\section{Stand-Alone Systems (AC)}

Military representatives were interested in systems of up to a few hundred kilowatts. For them, procurement of power conditioning units was not a problem, probably because military construction is so expensive to start with that the increment of cost for PV compatibility is relatively small. The problem of obtaining equipment for operation at arctic temperatures was mentioned. There was a short discussion on AC motor starting problems, especially in air-conditioning compressors. A concensus was expressed for a standard format for inverter overload specifications.

\section{Low Power DC Systems}

The remaining discussion centered on relatively small remote. DC systems. Discussed specifically were:

- Array/battery sizing

- Battery characterization and management

- Lightning protection

- DC-DC converters

- Maximum power point trackers 
Since DC systems tend to be used for low power remote applications, such systems are generally so far ranging and diverse in their make up as to make it virtually impossible to discuss in this context general power conditioning applications (except that most have in common batteries and regulators). Battery charge regulation evoked much discussion even though it is not power conditioning per se. The group would like to see handbook information on:

- Battery sizing, such as choice of dally deep cycle vs. long-term averaging.

- Battery management and its effects on lifetime and cost.

- Battery state of charge:

- Instrumentation, such as in situ removable specific gravity sensors.

Battery charge regulation is done almost universally with shunt dissipative regulators. Two manufacturers present built units of their own design; both had decided to build because suitable units were not available: One builds 50 units per week to satisfy his own needs and has no expansion plans. His product has a high labor cost but he believes an increased automation investment is not presently justifiable. The other manufacturer builds up to 300 units per run, at 20 to $360 \mathrm{~W}$ rating, which are supplied as OEM units.

The discussion then moved on to non-dissipative "switching" type regulators. The effect of switching rate upon battery lifetime was discussed. The battery manufacturers stated that slow rates would chemically "work" the plates and shorten life. They recommended switching frequencies above $100 \mathrm{~Hz}$. Above this frequency the electrolyte/plate interface is essentially a capacitor and the plates are not chemically "worked". This raised the question of possible electromagnetic interference by radiation from the PV array.

Lightning protection was a topic of general interest. A direct strike was presumed to be catastrophic but protection from induced surges from nearby strikes was also of concern. Again, a desire was expressed for a handbook 
of standardized information on economical lightning protection for small systems, with specific detalls on:
o Overvoltage: clamping and devices
- Transmission line effects and refiections of surges
- Disconnect devices such as fuzes and possible self-restoring devices.

A short discussion followed on availability of low power DC-DC converters. Apparently, there are few suppliers of converters, prices are high, and urits are of better quality than necessary. A desire was expressed Lur a line of "up-converters". which would allow the use of fewer solar cells and battery cells in series. Such a system would be of low voltage, 4 or 6 volts, yet run loads of 12 or 24 volts.

\section{Conclusions and Recommendations}

Topics requiring further consideration are:

- Standard inverter overload specification

- Handbook: Array-battery sizing

- Battery characterization

- Handbook: Lightning protection for small PV systems

- Battery state of charge sensing

- Effect of frequency choice of non-dissipative regulators on battery life. 